\title{
FEDERAL PREEMPTION AND PRIVATE LEGAL REMEDIES FOR POLLUTION
}

\author{
Robert L. GLICKSMAN ${ }^{\dagger}$
}

\section{INTRODUCTION}

In two 1981 decisions the Supreme Court held that the 1972 amendments to the Glean Water Act $^{1}$ preempted federal common-law nuisance actions in the area of water pollution. ${ }^{2}$ The Court also concluded that Congress did not authorize any implied private right of action under the Act for either monetary or injunctive relief. ${ }^{3}$ The two decisions, Middlesex County Sewerage Authority v. National Sea Clammers Association ${ }^{4}$ and City of Milwaukee v. Illinois, ${ }^{5}$ have eliminated all opportunities for private persons to seek damages under federal law for injuries caused by activities regulated under the Act.

The 1981 decisions, however, did not address whether the enactment of the Clean Water Act also preempted state common-law actions for monetary or injunctive relief. The Act appears to preserve such actions in the provision denying any congressional attempt to "restrict any right which any person ... may have under any statute or common law." The Milwaukee Court found, however, that this provision was not dispositive on the question of the preemption of federal common law, ${ }^{7}$ and the provision draws no explicit distinction between federal and state common-law actions. Recently, the Court of Appeals for the Seventh Circuit held that the Glean Water Act bars a state from

† Associate Professor of Law, University of Kansas. A.B. 1973, Union College; M.A. 1974, Harvard University; J.D. 1977, Cornell University. The author gratefully acknowledges the support of the University of Kansas General Research Fund in connection with the preparation of this Article.

The author thanks his colleagues Philip C. Kissam and Sidney A. Shapiro for their insightful and thought-provoking comments and suggestions on earlier drafts. The author also thanks John P. Healy, University of Kansas School of Law, Glass of 1986, for his research assistance.

1 Federal Water Pollution Control Act (Clean Water Act), Pub. L. No. 92-500, 86 Stat. 816 (1972) (codified as amended at 33 U.S.C. $\$ \S 1251-1376$ (1982)).

${ }^{2}$ See Middlesex County Sewerage Auth. v. National Sea Clammers Ass'n, 453 U.S. 1, 11, 21-22 (1981); City of Milwaukee v. Illinois, 451 U.S. 304, 317, 332 (1981).

3 See Middlesex County Sewerage Auth. v. National Sea Clammers Ass'n, 453 U.S. 1, 13-18 (1981).

4453 U.S. 1 (1981).

- 451 U.S. 304 (1981).

- 33 U.S.C. \& 1365(e).

7 See 451 U.S. at 328-29. 
applying its own common-law injunctive remedies to a source of pollutants located in another state, despite Congress's apparent attempt to preserve existing remedies. ${ }^{8}$ Two other courts subsequently reached the opposite conclusion, rejecting the Seventh Circuit's analysis. ${ }^{9}$

This Article analyzes whether state common-law damage or injunctive remedies have been preempted by the enactment of federal statutes not only in the area of water pollution, but also in the areas of air pollution and hazardous waste disposal. Part I of the Article describes four significant federal statutes controlling the discharge of pollutants, lists the possible forums for redressing individual harms caused by activities regulated under these federal statutes, and explores four different values that Congress and the courts have considered in deciding whether to authorize the use of private remedies. Part II examines the reasons for the limitations that have been imposed on the use of federal private remedies for redressing harm caused by pollution. Part II contends that although the Supreme Court properly held that Congress did not authorize implied private rights of action under the Clean Water Act, the Court's conclusion that the Act preempted federal common-law remedies was erroneous. In its 1981 decisions, the Court engaged in a questionable analysis of congressional intent by misunderstanding or ignoring the extent to which the preservation of federal common-law remedies promotes the values identified in Part I.

Part III addresses whether the federal pollution control statutes prohibit a state from applying its own common law to a source of pollution located in that state and to a source located in another state. The Article concludes that private actions under state common law have survived the enactment of the federal statutes controlling air and water pollution and hazardous waste disposal, except where Congress has explicitly preempted state common law. The Article contends that the Supreme Court's 1981 decisions concerning private remedies under federal law should not be extended to preempt state law private remedies, since a state's application of its own common-law remedies to a pollution source located within its own borders promotes the values identified in Part I. Preemption is also inappropriate and inconsistent with congressional intent when a state applies its common law to a pollution source located in another state. Although the application of state com-

${ }^{8}$ See Illinois v. City of Milwaukee, 731 F.2d 403, 410-11 (7th Cir. 1984), cert. denied, 105 S. Ct. 980 (1985).

B See Ouellette v. International Paper Co., 602 F. Supp. 264, 269 (D. Vt. 1985); State v. Ghampion Int'l Corp., 22 Env't Rep. Cas. (BNA) 1338 (Tenn. Ct. App. 1985). The Champion case involved an attempt to abate interstate pollution, while the plaintiffs in Ouellette sought both injunctive relief and damages. 
mon law in this context may be inconsistent with the two procedural values discussed in Part $I$, accommodation and legitimacy, it promotes the two substantive values, individual liberty and efficiency. Values of a substantive nature, especially if they are of constitutional derivation, should prevail over procedurally oriented values in determining the availability of private remedies. In an interstate pollution dispute, the substantive values dictate the preservation of state common-law remedies.

\section{The Choice of Remedial Alternatives}

\section{A. The Nature of Remedial Alternatives}

\section{Three Illustrative Problems}

The federal legislative effort to control the discharge of pollutants reflects a continuing attempt to balance an industrial society's need to consume natural resources and dispose of waste materials with its desire to protect personal health, safety, and property. ${ }^{10}$ The federal pollution control statutes reflect legislative determinations concerning the manner in which and the extent to which industry should be forced to reduce, or at least internalize, costs and harms that would otherwise be imposed on others. ${ }^{11}$ Where the nature or degree of harm caused by industrial pollution is uncertain, the statutes govern the allocation of risk between polluters and those exposed to their discharges. ${ }^{12}$

10 See, e.g., 33 U.S.C. $§ 1311(\mathrm{~b})(2)(\mathrm{A})$ (mandating achievement of limitations on the discharge of pollutants into navigable waters by applying "the best available technology economically achievable" for a category or class of "point sources," while making "reasonable further progress toward the national goal of eliminating the discharge of all pollutants"); 42 U.S.C. $\$ 7470$ (3) (1982) (One goal of the "prevention of significant deterioration" provisions of the Clean Air Act is "to insure that economic growth will occur in a manner consistent with the preservation of existing clean air resources."); $c f .42$ U.S.C. § 4331(b)(3) (1982) (The National Environmental Policy Act charges the federal government with a continuing responsibility to use all practicable means of attaining "the widest range of beneficial uses of the environment without degradation, risk to health or safety, or other undesirable or unintended consequences.").

11 For a seminal article analyzing the nature of external costs and the use of bargains in the free market to internalize those costs, see Coase, The Problem of Social Cost, 3 J.L. \& ECON. 1 (1960).

12 See, e.g., 33 U.S.C. $\S 1317$ (a)(4) (Effluent standards controlling the discharge of toxic pollutants "shall be at that level which the Administrator [of the federal Environmental Protection Agency (EPA)] determines provides an ample margin of safety."); 42 U.S.C. $\S 7412$ (b)(1)(B) (1982) (instructing the Administrator of the EPA to establish national emission standards for controlling hazardous air pollutants that will provide "an ample margin of safety to protect the public health"). For a discussion of the substantive and procedural issues raised by the need to regulate in the face of scientific uncertainty, see generally McGarity, Substantive and Procedural Discretion in Ad- 
The following three examples illustrate the kinds of decisions that must be made concerning how to allocate the risks of harm caused by industries performing economically and socially useful functions:

Example 1. Company $A$ operates an aluminum plant that emits nearly 3,000 pounds per day of fluoride gases, fumes, and particulate matter through a smokestack. $B$ has lived about a mile from the plant for the past few years and has complained of diarrhea, indigestion, back pain, coughing, shortness of breath, and difficulty sleeping. ${ }^{13}$

Example 2. Company $A$ mines a low-grade iron ore called taconite and processes the ore into pellets. Each day the company discharges about 67,000 tons of waste, known as tailings, into a large, nearby lake. The tailings contain a mineral that in morphology and chemistry is similar to asbestos, a known carcinogen. The lake is $B$ 's source of drinking water. ${ }^{14}$

Example 3. Company $A$ owns property used as an industrial landfill. Over the past several years, a variety of chemical and metallic wastes, including arsenic, vinyl chloride, benzene, lead, and cadmium, have been dumped in the landfill. These wastes are all highly toxic materials, and many are known to cause cancer, birth defects, and cell mutations. The landfill is now leaking, and the resulting leakage has contaminated a nearby underground aquifer. $B$ is one of many persons who drilled wells into the aquifer as their source of water for drinking and bathing. ${ }^{15}$

Each of these three examples can be modified by assuming that company $A$ discharges its wastes into the air, land, or water of state $A$, while $B$ experiences the effects of the company's discharges in state $B$.

Faced with these situations, Congress has endeavored to reconcile the conflicting uses of the air, water, and land resources involved. The legislature actually must make at least two kinds of choices. First, it must decide what criteria to apply in resolving conflicts. Do some uses merit more protection against the risk of externally imposed harm than others? Should some uses be granted greater freedom to impose risks

ministrative Resolution of Science Policy Questions: Regulating Carcinogens in EPA and OSHA, 67 GEO. L.J. 729 (1979) (arguing that the EPA and OSHA should resolve technical questions surrounding proposed regulation of carcinogenic chemicals "on the basis of result-oriented policies contained in their governing statutes" and that both agencies should continue efforts to streamline the decisionmaking processes employed to resolve cancer-related scientific issues).

13 These facts are taken from Reynolds Metals Co. v. Yturbide, 258 F.2d 321

(9th Cir.), cert. denied, 358 U.S. 840 (1958).

14 This example is based on a variation of the facts presented in Reserve Mining Co. v. United States, 498 F.2d 1073 (8th Cir. 1974).

is These facts are derived from United States v. Price, 523 F. Supp. 1055 (D.N.J. 1981), affd, 688 F.2d 204 (3d Cir. 1982). 
and harms on others? If so, why and to what extent? Second, Congress must specify the forum for deciding which uses merit legal protection and the procedures to be employed in resolving particular conflicts in resource use. Should all such decisions be made by a centralized federal administrative agency, or should disputes be resolved on an ad hoc basis by federal or state courts? Congress addressed these issues when it enacted four statutory programs for controlling air and water pollution and the disposal of hazardous wastes.

\section{Federal Statutory Pollution Control Mechanisms}

Congress has enacted a series of statutes designed to control pollutant discharges that may present risks to the public health and safety or to private property. In order to address problems such as those suggested in the first example above, the Glean Air $\mathrm{Act}^{16}$ authorizes the federal Environmental Protection Agency (EPA) to promulgate ambient air quality standards that limit concentrations of various air pollutants to levels required to protect the public health and welfare. ${ }^{17}$ The Act delegates to the states the responsibility for adopting and implementing plans to achieve the national standards by, for example, enforcing emission limitations on the operation of stationary sources of air pollutants. ${ }^{18}$ The EPA has the power to enforce the provisions of the Act by issuing administrative orders that specify a timetable for compliance and by initiating civil actions for injunctive relief and civil penalties. ${ }^{19}$ The statute also imposes criminal penalties, including fines and imprisonment, for certain willful violations of the Act. ${ }^{20}$ Finally, Congress has authorized private citizens to commence civil actions to enjoin persons violating emission limitations issued under the statute. ${ }^{21}$

The Clean Water Act is the principal federal statute designed to prevent harms like those caused by the taconite tailings in the second example. The core of the Act is contained in section 301(a), ${ }^{22}$ which prohibits the discharge of any pollutant from "point sources" into navi-

1842 U.S.C. $\S \S 7401-7626$ (1982).

17 See id. $\$ 7409$. The process for setting the national standards is described in Lead Indus. Ass'n v. EPA, 647 F.2d 1130, 1136-37 (D.C. Gir.), cert. denied, 449 U.S. 1042 (1980).

${ }_{18}$ See 42 U.S.C. $\$ 7410$ (a). Formulation of state implementation plans is discussed in Union Elec. Go. v. EPA, 427 U.S. 246, 249, 250 \& n.1 (1976). The Act also authorizes the EPA to promulgate national standards of performance, which establish emission limitations for new stationary sources, see 42 U.S.C. $\$ 7411$, and emission standards for moving sources, such as motor vehicles, see id. $\$ \S 7521-7551$.

${ }_{19}$ See 42 U.S.C. $\S 7413(\mathrm{a})$-(b).

${ }^{20}$ See id. $\S 7413$ (c).

${ }^{21}$ See id. § 7604(a).

2233 U.S.C. $\S 1311$ (a). 
gable waters except in compliance with regulations and under permits issued by the EPA or the states. ${ }^{23}$ The statute gives the EPA the duty to formulate effluent limitations that restrict the amounts or concentrations of pollutants discharged. ${ }^{24}$ The EPA typically issues these limitations in the form of regulations applicable to a category or class of point sources. $^{25}$ The limitations are transformed into obligations of particular point source dischargers through permits issued by the EPA or an appropriate state agency. ${ }^{26}$ Discharges from point sources must be within the applicable effluent limitations by the dates specified in the Act. $^{27}$ The enforcement mechanisms provided in the Clean Water Act are similar to those contained in the Glean Air Act. ${ }^{28}$

Congressional efforts to prevent problems like those raised by the third example above have resulted in two statutes, the Resource Conservation and Recovery Act (RCRA), ${ }^{29}$ and the Comprehensive Environmental Response, Compensation, and Liability Act (GERCLA). ${ }^{30}$ RGRA authorizes the EPA to formulate criteria for identifying hazardous wastes and to list those hazardous wastes that will be regulated. ${ }^{31}$ The agency must also adopt regulations that protect human health and the environment by controlling the activities of persons who generate, transport, treat, store, or dispose of listed hazardous wastes. ${ }^{32}$ Opera-

${ }^{28}$ See id. $\$ \S 1311(a), 1342$. A "point source" is "any discernible, confined and discrete conveyance," such as a pipe, channel, tunnel, or container, "from which pollutants are or may be discharged." Id. $\S 1362(14)$. The term "navigable waters" is defined as "the waters of the United States, including the territorial seas," $i d . \S 1362(7)$, and has been interpreted to include "all the waters within the geographic confines of the United States," United States v. Byrd, 609 F.2d 1204, 1209 (7th Gir. 1979) (citing United States v. Ashland Oil \& Transp. Co., 504 F.2d 1317, 1324 (6th Cir. 1974)).

24 See 33 U.S.C. $\$ \S 1311(\mathrm{e}), 1314,1362(11)$. These effluent limitations apply to existing point source dischargers.

${ }^{25}$ See, e.g., E.I. du Pont de Nemours \& Co. v. Train, 430 U.S. 112, 126-36 (1977). Like the Glean Air Act, the Clean Water Act mandates the establishment of a separate set of effluent limitations for newly constructed sources. See 33 U.S.C. $\S 1316(\mathrm{~b})(1)(\mathrm{B})$.

${ }_{26}$ See EPA v. California ex rel. State Water Resources Control Bd., 426 U.S. 200, 205 (1976) (citing 33 U.S.C. $\S \S 1319,1365$ (Supp. IV 1970) (current versions at 33 U.S.C. $\S \S 1319,1365(1982)))$.

27 See 33 U.S.C. $\$ 1311(\mathrm{~b})$.

${ }^{28}$ See id. $\$ \S 1319,1365$.

2942 U.S.C.A. \$§ 6902-6987 (West 1983 \& Supp. 1985). The Solid Waste Disposal Act ("RCRA") was most recently amended by Pub. L. No. 98-616, 98 Stat. 3224 (1984).

so 42 U.S.C. $\S \S 9601-9657$ (1982).

s1 See 42 U.S.C.A. § 6921 (West 1983 \& Supp. 1985).

32 These regulations govern activities such as recordkeeping; labeling; use of appropriate containers; use of a manifest system for tracking the movement of hazardous wastes from "cradle to grave" (from generation to disposal); treatment, disposal, and storage of wastes; location, design, and construction of waste treatment, disposal, and storage facilities; and methods of operation of these facilities. See 42 U.S.C.A. $§ \S 6922-$ 6924 (West 1983 \& Supp. 1985). 
tors of hazardous waste treatment, storage, and disposal facilities must obtain a permit issued either by the EPA or by the state in which the facility is located under a permit program approved by the EPA. ${ }^{33}$ The EPA can enforce the regulations promulgated under the statute by issuing administrative orders, initiating civil suits for injunctive relief and civil penalties payable to the government, and seeking criminal sanctions. $^{34}$

GERGLA, also known as the Superfund statute, differs from the other three statutes; it is not designed to control pollution from ongoing industrial operations. Rather, the statute is meant to facilitate the cleanup of inactive hazardous waste disposal sites that are releasing, or threatening to release, hazardous substances into the environment. The Act establishes a Hazardous Substance Response Trust Fund in the United States Treasury, ${ }^{35}$ the receipts of which are derived from taxes on crude oil and imported refined petroleum products ${ }^{36}$ and from general appropriations. ${ }^{37}$ The President is authorized to use money from the Fund to remove or remedy releases and threatened releases, ${ }^{38}$ and to seek reimbursement of costs incurred in the cleanup from persons who causèd such costs to be incurred. ${ }^{39}$ Private parties who incur costs in responding to a release, or threatened release, can recover those costs, under certain conditions, either from those responsible for causing the problem or from the Superfund. ${ }^{40}$

\section{Remedial Alternatives}

In formulating any pollution control program, Congress must make a series of decisions concerning the appropriate mix of public and private enforcement. First, the legislature must decide whether to preclude all private enforcement initiatives and rely exclusively upon the government's authority to enforce the statute. Second, if Congress concludes that some private remedies are appropriate, it must also decide whether such remedies should be available only where the regulated entity is violating the statute, only where the regulated entity is com-

33 Id. $\S \S 6925-6926$.

st Id. $\S 6928$.

ss See 42 U.S.C. $\S 9631$.

${ }^{36}$ See $i d$. $\S 9631(\mathrm{~b})(1)(\mathrm{A})$ (authorizing the use of funds received under 26 U.S.C. $\S \S 4611,4661(1982))$.

${ }^{37}$ See 42 U.S.C. $\$ 9631$ (b)(2). The Superfund was initially authorized at a level of $\$ 1.6$ billion.

s8 Id. $\S 9604$.

${ }^{39}$ Id. $\$ 9607$. These persons may also be liable for damages for injury to government-owned or controlled natural resources. See id. $\$ \S 9607(a)(1-4)(C), 9601(16)$.

10 See id. $\$ \S 9607(\mathrm{a})(1-4)(\mathrm{B}), 9611-9612$. 
plying with the statute but is nevertheless causing harm to the individual, or in both situations. ${ }^{11}$ Third, the legislature must define the available remedies and the procedures for pursuing those remedies. For example, Congress could authorize a person injured by pollution to seek relief solely through agency administrative processes. ${ }^{42}$ Alternatively, Congress could expressly authorize private judicial remedies. ${ }^{43}$ Under still another scenario, Congress could relegate individuals to common-law actions for monetary or injunctive relief. ${ }^{44}$ Finally, Congress could prevent the injured individual from taking any independent action against the polluter.

When Congress enacted the four pollution control statutes discussed above, ${ }^{45}$ it included in each a variety of techniques for statutory enforcement. ${ }^{46}$ It failed, however, to make clear in all cases the appropriate role of the injured individual in the enforcement process. Assume, for example, that in one of the three examples above, ${ }^{47} B$ can prove that company $A$ 's activities, which are regulated under one of the federal statutes, have caused or are causing harm to $B$ 's person or prop-

41 See Michelman, Pollution as a Tort: A Non-Accidental Perspective on Calabresi's Costs (Book Review), 80 YALE L.J. 647, 676-77 (1971) (arguing that private nuisance actions might be a useful complement to public environmental controls when activities that comply with regulatory controls cause harm to neighbors, but that subjecting activities that violate environmental regulations to private nuisance actions would engender a "wasteful overlap").

42 Of the four statutes, only CERCLA establishes an administrative compensation scheme. That scheme is of limited scope, however. It authorizes individuals to seek reimbursement from the Superfund for the cost of cleaning up hazardous waste sites. See 42 U.S.C. $\$ \S 9611-9612$. Individuals may not recover under CERCLA, either from the Fund or in litigation against private persons, for personal injury or damage to property. Under the other three statutes, private individuals can seek to prevent the imposition of future harm by participating in permit issuance proceedings, see, e.g., 33 U.S.C. $\S 1342(b)(3)$, by participating in the process of formulating a state implementation plan, see 42 U.S.C. $\$ 7410(a)(1)$, or by reporting alleged violations to the government.

1s The Clean Air and Water Acts and RGRA authorize private individuals to sue in federal district court for injunctive relief. See infra notes 88-100 and accompanying text. These statutes, however, do not permit the courts to award compensatory relief. See infra notes $90-91$ and accompanying text. A private person can seek recovery of cleanup costs from responsible parties under CERCLA. See 42 U.S.C. $§$ 9607(a)(14)(B).

44 The Supreme Court's decision in City of Milwaukee v. Illinois, 451 U.S. 304 (1981), discussed in Part II of this Article, involved the availability of federal commonlaw remedies. See infra text accompanying notes 199-277. Part III of this Article analyzes the availability of relief under state common law. See infra text accompanying notes $278-523$.

40 Congress, of course, has adopted a wide range of statutes to control pollution. This Article is confined to an analysis of preemption issues arising under the Clean Air and Water Acts, RCRA, and CERCLA. The conclusions reached in this Article, however, may also apply to other federal pollution control statutes.

16 See supra text accompanying notes 17-21, 28, 32-34 \& 37-40.

17 See supra text accompanying notes $13-15$. 
erty. According to the Supreme Court, Congress has preempted $B$ 's right to use federal common law to enjoin company $A$ 's activities or to recover compensation for the damage caused by company $A$ 's activities under the federal statutes. ${ }^{48}$ The four statutes provide no express right to recover damages, and the courts have refused to find that the statutes implicitly confer such a right. ${ }^{49}$ Thus, the only avenues for seeking monetary redress for $B$ 's injuries are those provided by state law. If the courts interpret the four statutes to preempt state as well as federal common-law remedies, the injured individual will be left without any forum for seeking compensation.

\section{B. The Values Served by Remedial Alternatives}

In enacting statutory schemes for the control of pollution, Congress, explicitly or implicitly, makes a series of value judgments. Other values are reflected in the constitutional provisions allocating power among the three branches of government and vesting certain rights in private individuals. If Congress fails to make clear its choices concerning the range of available statutory remedial mechanisms, the courts may be able to infer congressional intent by examining the extent to which the availability of a particular public or private remedy is consistent with these underlying statutory and constitutional value preferences.

This Article analyzes a series of cases in which the courts have ruled on the availability of private remedial mechanisms for pollution control. An attempt to derive a coherent body of legal doctrine to explain these cases could proceed on at least two levels. At the first level, the analysis would be based solely upon the express language of the opinions themselves. As Professor George Fletcher has argued, however, it is often hard to maintain faith that at this level "all the cases in a particular field of law coalesce[ ] in a consistent and coherent set of rules." $"$ As the analysis below indicates, the Supreme Court's conclusion that the Glean Water Act preempted the federal common law of nuisance and a circuit court's subsequent holding that state commonlaw nuisance actions have also been preempted in interstate pollution

18 See City of Milwaukee v. Illinois, 451 U.S. 304, 317 (1981).

49 See infra notes $120-39$ and accompanying text.

so Fletcher, Two Modes of Legal Thought, 90 YALE L.J. 970, 995 (1981); see also Sneed, The Art of Statutory Interpretation, 62 TEx. L. REv. 665, 665-66 (1983) (arguing that it is possible to reconcile apparently conflicting cases interpreting statutes if one accepts that "transcendent concerns substantially influence and sometimes dominate the manner in which statutes are interpreted"). 
disputes are difficult to justify at this textual level. ${ }^{51}$

Professor Bruce Ackerman recently pointed to "an increasing sense" that a legal analysis confined to the "particularities" of judicial or statutory texts does "not exhaust the relevant legal conversation." The text of a judicial opinion, like that of a statutory or constitutional provision, is open to interpretation..$^{63}$ No one interpretation of a case is definitive. What is involved in legal analysis, contends Professor Frederick Schauer, is not "the uniquely correct interpretation, but only an interpretation justified by the text." ${ }^{.54}$ Professor Ackerman is among those encouraging "a new kind of legal dialogue"55 and "a more conceptual form of analysis" by legal scholars. ${ }^{56}$ Similarly, Professor Fletcher suggests that legal analysis should move from the first, textual level to a second level, which involves the use of "a method for decoding the multiple messages of the case law. The method starts on the assumption that conflicting ways of thinking about the law, conflicting conceptions of Right, might coexist. This deeper conflict of principles and methods accounts for the surface inconsistency in the case law."'57

This Article analyzes the cases concerning private remedial mechanisms at both the textual and conceptual levels. It accepts Professor Richard Stewart's contention that certain bodies of law "bespeak a common social value" or set of values. ${ }^{58}$ It adopts Professor Stewart's suggestion that "[i]f we take seriously the possibility of a legal system giving expression to such basic values, then an inquiry into these values and their institutional realization is justified."

This Article asserts that it is possible to isolate at least four values that are reflected either in the provisions of the federal pollution control

S1 See infra text accompanying notes $227-32,366-67$ \& 405-06.

B2 B. ACKerman, Reconstructing AMERICAN LAW 42 (1984).

ss Cf. Schauer, An Essay on Constitutional Language, 29 UCLA L. REv. 797, 831-32 (1982) ("The Constitution has been written in a language, and a user of language must be taken to know and intend that the language is open to interpretation. . .. [T] [Te law cannot be certain, in large part because language itself is not certain.").

s4 Id. at 829.

ss B. ACKERMAN, supra note 52, at 72 (arguing that theorists must move beyond realism by laying the foundation for "a new kind of legal dialogue that seeks to explicate the complex character of the struggle for social justice in a liberal activist state").

so Id. at 5.

67 Fletcher, supra note 50, at 996-97.

38 Stewart, The Reformation of American Administrative Law, 88 HARV. L. Rev. 1669, 1671 (1975); see also B. ACKERMAN, supra note 52, at 20 (supporting legal analysis that moves beyond traditional legal realism by "relat[ing] individual conflicts to the systematic structural tensions of social life"); Sneed, supra note 50, at 685 ("The very task of judging is to bring to bear on particular problems one's experience and reflective considerations of competing values.").

so Stewart, supra note 58, at 1671. 
legislation or in the Constitution. These values are legitimacy, individual liberty, accommodation, and efficiency.$^{60}$ In some of the cases discussed in the Article, the courts' reliance on the four values is explicit. ${ }^{61}$ In other cases, the reliance is implicit and provides a justifiable explanation of the text of the court's opinion. ${ }^{62}$ Finally, in a number of cases the courts' failure to analyze the four values properly produced an incorrect result. ${ }^{63}$

This Article contends that the courts should explicitly analyze the four values in determining the availability of private remedial mechanisms for pollution control. ${ }^{64}$ The following section provides a brief in-

${ }^{60}$ These four values are not necessarily the only ones affected by the choice of private remedial mechanisms. They are, however, values that frequently surface in judicial and academic analyses of the availability of private remedial options to persons injured by pollution. See, e.g., Sneed, supra note 50, at 666 " "Transcendent values" relied on by courts in interpreting statutes include "(1) the separation of powers between the branches of government; (2) the federal character of our government; (3) the individual rights guaranteed by federal and state constitutions; and (4) the efficiency of government at all levels.").

The cases explored in this Article do not discuss economic efficiency, although the courts have attributed to Congress a desire to achieve efficiency in statutory enforcement. See, e.g., infra note 143 and accompanying text. Economic efficiency is nevertheless discussed in this Article because it might provide a justification for future legislative or judicial decisions, and because of its prominence in recent debates over the formulation of environmental policy. See, e.g., F. ANDERSON, D. MANDELRER \& A. Tarlock, Environmental Protection: Law and Policy 24-38 (1984) (collecting cases and other authorities) (discussing economists' views that increasing overall social utility in the use of natural resources requires consideration of the costs, including external costs, of different control mechanisms).

-1 See infra notes 146, 234 and accompanying text (relating to legitimacy); infra notes 140-42 and accompanying text (relating to individual liberty); infra text accompanying notes 108-09, 190-92 \& 457-60 (relating to accommodation); $c f$. Sneed, supra note 50, at $678 \mathrm{n} .62$ ("Concerns for judicial economy and respect for state courts, two transcendent values that animate all statutory interpretation, are explicit in decisions interpreting [42 U.S.C. § 1983]," a statute whose language is "deceptively simple" and whose legislative history is "ambiguous on many issues.").

62 See infra text accompanying notes 238 \& 240-41 (relating to legitimacy); infra text accompanying notes 186-89, 243 \& 247-48 (relating to individual liberty); infra text accompanying notes 143 \& 147 (relating to efficiency); see also Sneed, supra note 50 , at 688 (stating that in many cases involving statutory interpretation "most of the travail and uncertainty that might have attended the making of the decision is unrevealed" on the face of the opinion).

63 See infra text accompanying notes 110-12 (relating to legitimacy); infra text accompanying notes 114-16, 242, 246, 249-52 \& 436-56 (relating to individual liberty); infra text accompanying notes 253-54 (relating to accommodation).

o. See infra text accompanying notes 387-99, 423-68 \& 501-23; see also Sneed, supra note 50, at 672 (asserting that in interpreting ambiguous statutory provisions courts "generally should animate their work with their understanding of the Framers' constitutional vision"); id. at 665 (" $[T]$ ranscendent concerns substantially influence and sometimes dominate the manner in which statutes are interpreted. These concerns derive mainly from the Constitution and to a lesser degree from judicial attention to the goal of governmental efficiency."); id. at 669 ("The forces of federalism on statutory interpretation [are] . . . strong in preemption cases."); $i d$. at 684 (contending that it is 
troductory description of these values. Parts II and III of the Article explore their role in cases concerning private remedial mechanisms for pollution control.

\section{Legitimacy}

For purposes of this Article, a decision to regulate private conduct $^{65}$ is "legitimate" if those affected by the decision accept the decisionmaking process even if they do not agree with the merits of the decision. A regulatory decision characterized by legitimacy has a relatively high degree of credibility. Persons required to conform their conduct or expectations to a particular statutory, administrative, or judicial decision are more likely to perceive the decision as legitimate if the decisionmaking process has one or more of the following characteristics. First, legitimacy is enhanced if the decisionmaker is politically accountable. For example, a regulatory decision reached by an elected public official, or even a bureaucrat subject to various legislative oversight mechanisms, may provoke less hostility from the regulated entity than would a similar decision reached by a federal judge who is largely exempt from such mechanisms, and whose views are not necessarily representative of community values. ${ }^{68}$ Second, public participation in the decisionmaking process will increase the legitimacy of a particular decision. ${ }^{67}$ Third, when a decisionmaker is perceived to be well informed,

legitimate for courts to rely on "transcendent concerns" in interpreting unclear statutes because these concerns "are based upon constitutional considerations and the nature of judicial decisionmaking").

68 Private conduct can be regulated not only by legislative or administrative action, but also by a court decree in a common-law tort action such as nuisance.

${ }_{68}^{6}$ See Stewart \& Sunstein, Public Programs and Private Rights, 95 Harv. L. Rev. 1195, 1209, 1218, 1225-26 (1982); Sunstein, Section 1983 and the Private Enforcement of Federal Law, 49 U. CHI. L. REv. 394, 418 (1982); see also Pierce, Regulation, Deregulation, Federalism, and Administrative Law: Agency Power to Preempt State Regulation, 46 U. PrrT. L. REv. 607, 664 (1985) (stating that the political and constitutional legitimacy of federal agencies is "well established," even though they are not as politically accountable as Congress).

Some, however, have expressed concerns regarding the legitimacy of administrative rulings promulgated by regulatory agencies. See, e.g., Process Gas Consumers Group v. Consumers Energy Council, 453 U.S. 1216 (1983) (White, J., dissenting) (invalidating the legislative veto merely guarantees that "the independent agencies, once created, for all practical purposes are a fourth branch of the government not subject to the direct control of either Congress or the Executive Branch"); see also PRESIDENT's CoMM. ON Admin. Management, Report of the President's Committee on AdministraTIVE Management 40 (1937) (attacking independent agencies as a "headless fourth branch of government").

${ }_{67}$ See Pierce, supra note 66, at 664; Stewart, Pyramids of Sacrifice? Problems of Federalism in Mandating State Implementation of National Environmental Policy, 86 Yale L.J. 1196, 1231 (1977) [hereinafter cited as Stewart, Pyramids of Sacrifice]. For an argument that the "interest representation" model of administrative law ulti- 
her decisions will be more credible. ${ }^{68}$ Fourth, the perception that a regulatory decision is fair, in that similarly situated persons have been and will be subject to the same requirements, will enhance the legitimacy of the decision. Finally, a system in which regulatory decisions, and the consequences of noncompliance with those decisions, are certain and predictable will be more acceptable to regulated persons and to the community at large than a system lacking these attributes.

\section{Individual Liberty}

This Article makes no attempt to provide an all-encompassing definition of individual liberty. Rather, the analysis reflects the proposition that individual liberty will be enhanced by a system that provides freedom from arbitrary governmental interference and maximizes self-determination, ${ }^{69}$ while at the same time protecting the basic personal integrity of the individual from harms imposed by others.

The framers of the Constitution established our tripartite system of government based on the conviction that the separation of federal governmental authority into three separate branches was necessary to prevent any one arm of the government from unduly intruding upon personal freedom. ${ }^{70}$ Similarly, the federal system of government pro-

mately fails as a general structure of legitimation, see generally Stewart, supra note 58, at 1760-90, 1802-13 (urging that the current interest representation system involves major difficulties in implementation, financing, and the ability to formulate general rules of decision).

${ }^{68}$ Cf. Hines, Nor Any Drop to Drink: Public Regulation of Water Quality, 52 IowA L. REv. 186, 199 (1966) (asserting that judges may lack technical and scientific expertise to make informed decisions in pollution control cases).

${ }^{60}$ Cf. Stewart, Pyramids of Sacrifice, supra note 67, at 1230-32 (contending that "important values of local self-determination in the selection of environmental policies and the deployment of local government resources" must be balanced against justifications for federally mandated environmental controls).

${ }^{70}$ See Immigration \& Naturalization Serv. v. Chadha, 462 U.S. 919, 949-51 (1983). The Chadha Court quoted from James Wilson's statements at the Constitutional Convention:

"Despotism comes on mankind in different shapes. Sometimes in an Executive, sometimes in a military, one. Is there danger of a Legislative despotism? Theory \& practice both proclaim it. If the Legislative authority be not restrained, there can be neither liberty nor stability; and it can only be restrained by dividing it within itself, into distinct and independent branches. In a single house there is no check, but the inadequate one, of the virtue and good sense of those who compose it."

Id. at 949 (quoting $1 \mathrm{M}$. FarRand, The Records of the Federal Convention OF 1787, at 254 (1911)); see also The FeDERALIST No. 51, at 356 (A. Hamilton or J. Madison) (B. Wright ed. 1961) (arguing that the separateness and distinctness of the three branches are essential to the preservation of liberty: "Ambition must be made to counteract ambition. . . . The constant aim is to divide and arrange the several offices in such a manner that each may be a check on the other . . . ."). 
motes individual liberty by allowing for noncentralized decisionmaking. As Professor Stewart has noted, a federal system

encourages self-determination by fragmenting governmental power into local units of a scale conducive to active participation in or vicarious identification with the process of public choice. This stimulus to individual and collective education and self-development is enriched by the wide range of social, cultural and physical environments which noncentralized decisionmaking encourages. ${ }^{71}$

The protection of the integrity of state political processes and the principle of separation of powers, therefore, promote individual liberty.

Although the courts have not recognized a federal constitutional right to a decent environment, ${ }^{72}$ governmental protection against private intrusions upon an individual's health, safety, and property arguably enhances individual liberty and is thus consistent with the due process clauses of the fifth and fourteenth amendments. ${ }^{73} \mathrm{~A}$ regulatory decision that assists the individual in halting, or at least receiving compensation for, such intrusions, therefore, may also promote individual liberty. ${ }^{74}$

\section{Accommodation}

A third value that Congress may seek to promote in the enactment of pollution control programs-one which the framers of the Constitu-

71 Stewart, Pyramids of Sacrifice, supra note 67, at 1210-11 (footnotes omitted); see also Pierce, supra note 66, at 645-46 (citing Gray, Regulation and Federalism, 1 YALE REG. J. 93 (1983)) (suggesting that one advantage of state and local regulation over federal regulation is that the state and local regulators are more likely to be able to respond promptly to local needs). For an argument that a diminished role for the Supreme Court in issues involving interstate commerce and the federal preemption of state law will encourage political responsibility at the national and state levels and permit responsiveness to a fuller range of interests in the allocation of natural resources, see Tarlock, National Power, State Resource Sovereignty and Federalism in the 1980's: Scaling America's Magic Mountain, 32 U. KaN. L. REv. 111 (1983).

${ }_{72}$ See, e.g., Tanner v. Armco Steel Corp., 340 F. Supp. 532, 535 (S.D. Tex. 1972); Environmental Defense Fund v. Corps of Eng'rs, 325 F. Supp. 728, 739 (E.D. Ark. 1971). See generally T. Schoenbaum, Environmental Policy Law 236-37 (1985) (citing cases in which plaintiffs have asked the court to recognize a constitutional right to a decent environment).

73 See U.S. CoNST. amend. V ("[N]or shall any person . . . be deprived of life, liberty, or property, without due process of law; nor shall private property be taken for public use, without just compensation."); see also infra notes 329-48 and accompanying text (contending that congressional abolition of all common-law actions for compensatory relief would raise serious due process concerns).

${ }^{74}$ Cf. 42 U.S.C. $\S 4331$ (c) (1982) ("The Congress recognizes that each person should enjoy a healthful environment ...."); W. RODGERS, HANDBOOK ON ENVIRONMENTAL LAW $\S 2.1$, at 2 (Supp. 1984) (discussing writers who argue that nuisance law protects against intrusion upon "some version of unique human rights"). 
tion sought to achieve by creating a federal system of government-is the accommodation of conflicting interests. The desire of more than one entity to use the same natural resource may give rise to at least three different kinds of conflicts: conflicts between the interests of two or more states, conflicts between state and federal interests, and conflicts between the interests of regulated industrial entities and those of persons adversely affected by pollutant discharges. First, two different states may disagree on the appropriate use of a particular resource. For example, state $A$ may designate a body of water as the appropriate receptacle for the effluents of an industrial discharger located in that state. State $B$, located downstream on the same body of water, may object that the company's discharges reduce the value of the water to state $B$ residents for drinking or recreational purposes. ${ }^{75}$ Second, a state's decision to permit a certain level of pollution by its industries may conflict with a federal environmental standard or damage a resource important to national environmental interests, such as a national park, or to economic interests, such as a navigable waterway used in interstate commerce. ${ }^{78}$ Finally, many of the provisions of the federal pollution control statutes reflect an effort to balance the interests of industry in avoiding costly pollution control requirements and the desire to protect the health of persons exposed to industrial emissions. ${ }^{77}$ The desirability of a particular private remedy might depend on its capacity for smoothly accommodating the potentially conflicting interests of the states, the national government, consumers, and industry. The accommodation of the conflicting interests of those affected by the federal pollution control laws enhances the likelihood that those entities will cooperate in seeking to achieve the substantive goals reflected in those laws.

\section{Efficiency}

A legislature designing a regulatory system of pollution control is also motivated by efficiency concerns, both in the use of natural resources and in the use of governmental resources to enforce the regulatory obligations. An economically efficient allocation of resources is one that maximizes the total value of production as measured by consumers'

${ }^{78}$ See Stewart, Pyramids of Sacrifice, supra note 67, at 1215 ("[S]pillover impacts of decisions in one jurisdiction on well-being in other jurisdictions generate conflicts and welfare losses not easily remedied under a decentralized regime.").

78 See id. at 1212 (explaining that "any individual state . . . may rationally decline unilaterally to adopt high environmental standards . . . for fear that the resulting environmental gains will be more than offset by the movement of capital to other areas with lower standards"). In such a situation, all states may be better off if federal standards are imposed.

7 See supra note 10 and accompanying text. 
willingness to pay for various commodities produced by a given resource allocation. ${ }^{78}$ Efficiency may be threatened if industry is free to discharge pollutants without liability for resulting harms. For example, if company $A$ in the second illustrative example above ${ }^{79}$ is free to discharge its tailings into the lake without incurring liability for the harm caused by the discharges, the company is able to

shift part of the cost of producing [its] good[s] to $[B$ and the other users of the lake], who in effect [partially] subsidize [company $A$ 's] cost of production by absorbing the [harm] without charge. Thus, the ultimate price charged [and paid] for [company $A$ 's] good[s] may be understated because it does not [accurately] reflect all of the [costs] of production. ${ }^{\mathbf{8 0}}$

This distorted price signal may result in greater demand for and production of the company's goods than would be the case if the costs of harm to the environment were imposed on the company and reflected in the price of its goods. Absent an accurate representation of the true opportunity cost of producing company $A$ 's goods, the company's prices will not insure that resources will gravitate to their most valued use. ${ }^{81}$ If they do not, the market will fail to operate efficiently. This kind of misallocation of resources, or market failure, may be avoided by permitting $B$ to bring a private action against the company for compensatory damages. An award of damages will tend to promote a more efficient level of production by taxing company $A$ for the costs it imposes on others. ${ }^{82}$ In establishing a pollution control program, the legislature also may want to achieve efficiency in enforcement by maximizing the degree of compliance achieved as a result of a given outlay of enforce-

78 See R. Stewart \& J. Krier, Environmental Law and Policy 112 (Supp. 1982). An economically efficient allocation of resources can also be defined as one that results in a given level of output at the least cost. It has been suggested that in seeking to achieve an efficient allocation of natural resources, one should attempt to minimize the sum of four different types of costs associated with the use of those resources: (1) damage costs occurring as a result of pollution; (2) abatement costs occurring as a result of pollution; (3) avoidance costs incurred in preventing or minimizing the adverse effects of pollution once it has occurred; and (4) transaction costs involved in allocating resources, including the costs of selecting and applying liability rules. See id. at $145 ; c f$. Michelman, supra note 41 , at 650-51 (discussing Calabresi's definition of primary, secondary, and tertiary costs).

79 See supra text accompanying note 14.

${ }^{80}$ F. ANDerson, D. MANDelker \& A. TARLOCK, supra note 60 , at 31.

81 See I. VAN LIER, ACID RAIN AND INTERnational LAw 56-58 (1981).

${ }^{82}$ Cf. Stewart \& Sunstein, supra note 66, at 1297 (Private actions awarding compensatory damages "tend automatically to promote a more efficient level of compliance [with regulatory norms] by taxing defendants for the costs they impose upon others.") (footnote omitted). 
ment expenditures. ${ }^{83}$

\section{Value Achievement as a Means of Selecting Remedial Alternatives}

Parts II and III of this Article discuss a series of remedial alternatives under both federal and state law for redressing harms caused by activities regulated under the four major federal pollution control statutes. Some courts have concluded that Congress failed to indicate clearly whether these remedial alternatives are available to private persons. In the absence of explicit legislative guidance, the courts have had to search for implicit congressional intent in determining the availability of private remedies. In some cases, the courts appear to have divined this intent by considering whether the values identified above would be promoted by preserving or precluding resort to a particular remedy. ${ }^{\mathbf{8 4}}$ Based on this analysis, the courts have held that Congress intended to bar implied statutory private rights of action, federal common-law actions, and state common-law actions for redressing harms caused by interstate pollution.

This Article contends that in some of these cases the courts' analysis of congressional intent was mistaken or incomplete. The following chart indicates that of the five remedial alternatives discussed in this Article, only one-implied statutory private rights of action-fails to

83 See Sneed, supra note 50, at 665 \& n.3 (contending that courts interpret statutes in a manner likely to promote "governmental efficiency," which concerns the achievement of governmental objectives "without undue costs or administrative burdens"); id. at 670-71 n.28; id. at 676 ("A recurring concern in statutory interpretation cases that is not directly rooted in specific provisions of the Constitution is the protection of efficiency in government."); see also supra note 78 (discussing transaction costs).

${ }^{84} C$. Sneed, supra note 50, at 667-68 (stating that a "vital aspect of the 'art' of [statutory] interpretation" has been the influence of "a transcendent concern for the separation of powers between the three branches of the federal government," a concern that is "rooted in the Constitution"); id. at 672 ("Interpretation of statutes is influenced plainly and appropriately by the letter and spirit of the Bill of Rights . . . ."). 
promote any of the four values:

\section{DO PRIVATE REMEDIAL ALTERNATIVES PROMOTE RELEVANT VALUES?}

\begin{tabular}{|c|c|c|c|c|c|}
\hline & \multicolumn{4}{|c|}{ VALUES } \\
\hline & & Legitimacy & $\begin{array}{l}\text { Individual } \\
\text { Liberty }\end{array}$ & $\begin{array}{c}\text { Accommo- } \\
\text { dation }\end{array}$ & Efficiency \\
\hline $\begin{array}{l}R \\
E \\
M \\
E \\
D\end{array}$ & \begin{tabular}{|l} 
Automatic \\
Statutory \\
Injunctive \\
Relief \\
\end{tabular} & YES & YES & NO & - \\
\hline $\begin{array}{l}\text { I } \\
\text { A } \\
\text { L }\end{array}$ & $\begin{array}{l}\text { Implied } \\
\text { Statutory } \\
\text { Rights of } \\
\text { Action } \\
\end{array}$ & NO & NO & - & NO \\
\hline $\begin{array}{c}A \\
L\end{array}$ & $\begin{array}{l}\text { Federal } \\
\text { Common } \\
\text { Law } \\
\end{array}$ & YES & YES & YES & YES \\
\hline $\begin{array}{l}\mathrm{R} \\
\mathrm{N} \\
\mathrm{A}\end{array}$ & $\begin{array}{l}\text { State } \\
\text { Common } \\
\text { Law } \\
\text { (Intrastate) } \\
\end{array}$ & YES (?) & YES & - & YES \\
\hline E & $\begin{array}{l}\text { State } \\
\text { Common } \\
\text { Law } \\
\text { (Interstate) } \\
\end{array}$ & NO (?) & YES & NO (?) & YES \\
\hline
\end{tabular}

Contrary to the Supreme Court's analysis in its 1981 decisions, ${ }^{85}$ the availability of federal common-law actions would promote all four of these values. Moreover, the holdings in the Court's 1981 decisions, regardless of their merits, should not be extended to preempt state common-law actions for intrastate pollution, because these actions are strongly supported by three of the four values and are not inconsistent with the remaining value.

State common-law actions for interstate pollution are also supported by a consideration of the four values. Although these actions

85 See Middlesex County Sewerage Auth. v. National Sea Glammers Ass'n, 453 U.S. 1, 11, 21-22 (1981); City of Milwaukee v. Illinois, 451 U.S. 1, 13-18 (1981). 
may be inconsistent with the values of legitimacy and accommodation, their preservation promotes the remaining two values, individual liberty and efficiency. The latter two values are substantive in nature and should be given priority by the courts. They reflect society's determinations of the extent to which industry should be forced to internalize the costs resulting from pollution and of the appropriate allocation of the risk of pollution-caused harm. ${ }^{86}$ The values of legitimacy and accommodation, on the other hand, are primarily procedural in nature. They assist in determining who should make the decisions concerning appropriate levels of risk allocation and cost internalization and which procedures should be followed for making those decisions. These values for the most part are employed to choose the most effective means of achieving the substantive goals. The process-oriented values should, therefore, yield to the substantive values where the two sets of values conflict. The choice between procedural and substantive values should be especially clear where the latter are of constitutional derivation. In the case of an interstate pollution dispute, several components of the individual liberty value may reflect a constitutional mandate that a state and its citizens be afforded the means of protecting themselves against and seeking redress for harms originating from outside that state. $^{87}$

\section{Federal Private Remedies}

\section{A. Express Statutory Remedies}

\section{Recovery of Compensatory Damages}

Three of the four federal pollution control statutes addressed in this Article contain provisions authorizing private citizens ${ }^{88}$ to bring suit in federal district court against persons alleged to be in violation of certain substantive statutory requirements, such as limitations on emis-

${ }^{88}$ See supra notes $10-11$ and accompanying text.

87 See infra notes 147, 452-56 and accompanying text (contending that, in situations where the values conflict, priority should be afforded to those derived from the Constitution, such as individual liberty).

88 The citizen suit provisions in the Clean Air Act and RCRA authorize "any person" to bring suit. See 42 U.S.C.A. § 6972(a) (West 1983 \& Supp. 1985); 42 U.S.C. \$ 7604(a). The Clean Water Act authorizes suits by "any citizen," 33 U.S.C. $\S 1365$ (a), which is defined as "a person or persons having an interest which is or may be adversely affected." Id. $\S 1365(\mathrm{~g})$. The Supreme Court has construed this provision to mean "all persons possessing standing under [the] Court's decision in Sierra Club v. Morton, 405 U.S. 727 (1972)." Middlesex County Sewerage Auth. v. National Sea Clammers Ass'n, 453 U.S. 1, 16 (1981) (citing S. REP. No. 1236, 92d Cong., 2d Sess. $146(1972))$. 
sions of air pollutants or on discharges of pollutants into navigable waters. $^{89}$ The citizen suit provisions of these three acts do not, however, explicitly authorize the recovery of compensatory or other damages by private plaintiffs, and the courts have refused to construe the statutes to permit such an award. ${ }^{80} \mathrm{~A}$ private party can seek damages under

89 The citizen suit provisions of these and other federal pollution control statutes are quite similar in their structure and language. Many were patterned after the citizen suit provisions included in the Clean Air Act in 1970. See Miller, Private Enforcement of Federal Pollution Control Laws (pt. 1), 13 EnvTL. L. REP. 10,309, 10,311 (1983) [hereinafter cited as Miller, Private Enforcement (pt. 1)] ("There has been a tendency to literally 'lift' [the citizen suit provision] from the Clean Air Act and transpose it with only [minor] changes into other environmental statutes."). The Clean Air and Water Acts limit the substantive violations that can be the appropriate subject of a citizen suit. See 33 U.S.C. $§ 1365(f) ; 42$ U.S.C. $\$ 7604(f)$. RCRA's citizen suit provision simply authorizes suit against "any person ... who is alleged to be in violation of any permit, standard, regulation, condition, requirement, or order which has become effective pursuant to this [Act]." 42 U.S.C.A. $\$ 6972(a)(1)(A)$ (West Supp. 1985).

A detailed analysis of the various federal citizen suit provisions is beyond the scope of this Article. For a thorough discussion of these provisions, see generally Fadil, Citizen Suits Against Polluters: Picking Up the Pace, 9 HARv. ENvTL. L. REv. 23 (1985) (discussing factors responsible for the degree of citizen enforcement and the rise of citizen suits under the Clean Water Act); Miller, Private Enforcement of Federal Pollution Control Laws (pts. 1-3), 13 ENVTL. L. REP. 10,309 (1983), 14 ENVTL. L. REP. 10,063, 10,407 (1984); Schwartz \& Hackett, Citizen Suits Against Private Industry Under the Clean Water Act, 17 NAT. Resources LAW. 327 (1985) (discussing claims, defenses, and remedies under the Glean Water Act). See also F. Anderson, D. MANDELKER \& A. TARLOCK, supra note 60 , at 445-47 (discussing standing requirements); J. Bonine \& T. McGarity, The Law of Environmental Protection 987-92 (1984). The citizen suit provisions also authorize private persons to sue the Administrator of the EPA for an alleged failure to perform nondiscretionary acts. See 33 U.S.C. § 1365(a)(2); 42 U.S.C.A. § 6972(a)(2) (West 1983 \& Supp. 1985); 42 U.S.C. $§ 7604(a)(2)$. This Article addresses the rights of private persons against polluters who have allegedly injured them, rather than their rights against the government for failing to implement or for improperly implementing the pollution control statutes. For an analysis of the use of citizen suit provisions to force agency action, see $\mathrm{J}$. BONINE \& T. MCGARITY, supra, at 869-99.

${ }^{90}$ See, e.g., Middlesex County Sewerage Auth. v. National Sea Glammers Ass'n, 453 U.S. 1, 12, 17 n.27, 18 (1981) (concluding that the legislative history of the Clean Water Act reveals a congressional intent to limit private remedies to those expressly provided); Gity of Evansville v. Kentucky Liquid Recycling, Inc., 604 F.2d 1008, 1014 15 (7th Cir. 1979) (The Clean Water Act does not authorize private actions for damages.), cert. denied, 444 U.S. 1025 (1980); Pawtuxet Cove Marina, Inc. v. Ciba-Geigy Corp., 21 Env't Rep. Cas. (BNA) 1390, 1391 (D.R.I. 1984); Fairview Township v. EPA, 593 F. Supp. 1311, 1315 (M.D. Pa. 1984) ("Monetary damages are not available under the Clean Water Act.") (citations omitted); see also S. REP. No. 1196, 91st Cong., 2d Sess. 36-39, 64-65 (1970) (The Glean Air Act's citizen suit provision does not provide for damage actions; if, however, damages can be shown, remedies under other laws are still available.); J. BonINe \& T. MCGARITY, supra note 89 , at $989-90$ (collecting cases); Miller, Private Enforcement (pt. 1), supra note 89, at 10,321; Comment, The Dilemma of the Downstream State: The Untimely Demise of Federal Common Law Nuisance, 11 B.C. Envtl. AfF. L. Rev. 295, 394 (1984). But cf. 30 U.S.C. $\S 1270(f)(1982)$ (providing a cause of action for damages to person or property arising from violations of the Surface Mining Control and Reclamation Act of 1977). The Clean Water Act does authorize the assessment of civil penalties in a citizen suit. See 
CERCLA, but recovery is limited to reimbursement of certain costs incurred as a result of a release or threatened release of hazardous substances from a facility. ${ }^{91}$ Recoveries for personal injuries or damage to private property are not available.

\section{Injunctive Relief}

The citizen suit provisions of the Clean Air and Water Acts and RCRA authorize the courts to enjoin allegedly unlawful polluting activities. ${ }^{22}$ A plaintiff who proves an ongoing statutory violation, however, is not automatically entitled to injunctive relief. In Weinberger $v$. Romero-Barcelo, ${ }^{93}$ the Supreme Court held that because an injunction is an equitable remedy a plaintiff under the citizen suit provision of the Clean Water $\mathrm{Act}^{\mathbf{9 4}}$ is not entitled to injunctive relief as a matter of course upon proof of a statutory violation. ${ }^{95}$

According to the Court in Romero-Barcelo, an injunction should be issued only where it " is essential in order effectually to protect property rights against injuries otherwise irremediable." "96 Tradition-

33 U.S.C. $\S 1365(a)$. Such penalties are payable to the federal government, not to the private plaintiff. See Miller, Private Enforcement (pt. 2), supra note 89, at 10,079.

91 See 42 U.S.C. $\S 9607(\mathrm{a})(1-4)(\mathrm{B})$.

92 For example, the Clean Water Act vests the federal district courts with the authority "to enforce an effluent standard or limitation." 33 U.S.C. § 1365(a). For a description of the types of injunctive relief that are appropriate under the citizen suit provisions, see Miller, Private Enforcement (pt. 2), supra note 89, at 10,075-79. See generally Farber, Equitable Discretion, Legal Duties, and Environmental Injunctions, 45 U. PITT. L. REV. 513 (1984) (classifying different types of injunctions, such as enforcement injunctions and compliance injunctions); Plater, Statutory Violations and Equitable Discretion, 70 CALIF. L. Rev. 524 (1982) (discussing the effects of statutes on equitable discretion).

93 456 U.S. 305 (1982).

94 33 U.S.C. $\S 1365$.

os See 456 U.S. at 311-20; see also id. at 321-22 (Powell, J., concurring) (finding "no indication that Congress intended to limit the court's equitable discretion"). In Romero-Barcelo the Governor of Puerto Rico and residents of the island sued the United States Navy to enjoin the Navy from continuing its weapons training activities off the coast of Puerto Rico. These activities caused ordnance to fall into the sea when Navy pilots inadvertently missed land-based targets. Id. at 307. The Clean Water Act prohibits the discharge of pollutants into navigable waters without a permit, see 33 U.S.C. $§ 1311(\mathrm{a})$, and defines the term "pollutant" to include munitions. See id. $\S 1362(6)$. Because the Navy was discharging ordnance without a permit from the EPA, the district court found that the Navy was violating the Act. See 456 U.S. at 30708 (citation and footnote omitted). The court ordered the Navy to seek a permit from the EPA, but it refused to enjoin the training activities pending the EPA's consideration of the permit application. See id. at 309-10. The Court of Appeals reversed and instructed the district court to order the Navy to cease the violation until it received a permit. See id. at 310 (citation omitted). The Supreme Court reversed.

98 456 U.S. at 312 (quoting Cavanaugh v. Looney, 248 U.S. 453, 456 (1919)). The Court stated that plaintiffs have "repeatedly" been required to demonstrate irreparable injury and the inadequacy of legal remedies before receiving injunctive relief in 
ally, the federal courts have compared the harms that would be suffered by the defendant and plaintiff if injunctive relief were granted or refused. ${ }^{97}$ The courts also consider the effect on the public interest of issuing an injunction. ${ }^{88}$ The Court in Romero-Barcelo concluded that, unless Congress clearly manifests its intention to control the exercise of the district court's discretion, a court is not obligated to issue an injunction for every statutory violation. ${ }^{99}$ The Court then reviewed the language, structure, and legislative history of the Clean Water Act and determined that the fact that "the scheme as a whole contemplates the exercise of discretion and balancing of equities militates against the conclusion that Congress intended to deny courts their traditional equitable discretion in enforcing the statute."100

federal court. See id. at 312 (citing Rondeau v. Mosinee Paper Corp., 422 U.S. 49, 61 (1975); Sampson v. Murray, 415 U.S. 61, 88 (1974); Beacon Theaters, Inc. v. Westover, 359 U.S. 500, 506-07 (1959); Hecht v. Bowles, 321 U.S. 321, 329 (1944)).

${ }_{97}$ See Romero-Barcelo, 456 U.S. at 312 (citing Yakus v. United States, 321 U.S. 414,440 (1944)). Among the factors considered by the federal courts in pollution cases are the technical and financial feasibility of compliance, the existence (or lack thereof) of a threat to public health, and the ability of the court to manage the remedy sought. See Miller, Private Enforcement (pt. 2), supra note 89, at 10,077 (collecting cases).

${ }_{98} \mathrm{See}$ Romero-Barcelo, 456 U.S. at 312.

99 See id. at 313 (citing Porter v. Warner Holding Co., 328 U.S. 395, 398 (1946)). The district court in Romero-Barcelo found that the Navy's discharges had not harmed the quality of the waters off the coast of Puerto Rico. See Romero-Barcelo, 456 U.S. at 307. The Supreme Court also stated that "the [Navy's] discharge of ordnance had not polluted the waters." Id. at 315.

Arguably, this fact should not have been considered in determining whether the Navy's violation should have been enjoined. The principal pollution control mechanism in the Clean Water Act is a series of technology-based effluent limitations, which are to be applied uniformly to a class or category of dischargers based on the degree of effluent reduction that those dischargers are technically or economically capable of achieving. See, e.g., 33 U.S.C. $\$ \S 1311$ (b), 1314(b) (calling for effluent limitations for certain point sources "which shall require the best practicable control technology currently available as defined by the Administrator pursuant to section 1314(b)"'). In establishing these effluent limitations, the EPA is not authorized to consider the assimilative capacity of the receiving waters. Indeed, in establishing the effluent limitation mechanism in the 1972 amendments to the Clean Water Act, Congress clearly rejected as unworkable previous federal attempts at water pollution control based on the impact of discharges on receiving water. See Crown Simpson Pulp Co. v. Costle, 642 F.2d 323, 327-28 (9th Cir.), cert. denied, 454 U.S. 1053 (1981); Weyerhaeuser Co. v. Costle, 590 F.2d 1011, 1041-44 (D.C. Gir. 1978); see also F. Anderson, D. Mandelker \& A. TARLock, supra note 60, at 342 ("In 1972 Congress concluded that the water quality approach was not working.").

100 Romero-Barcelo, 456 U.S. at 316. The Court noted that the Act's scheme of phased compliance "suggests that this is a statute in which Congress envisioned, rather than curtailed, the exercise of discretion." Id. But cf. Farber, supra note 92, at 524-27 (A more insightful reading of Romero-Barcelo reveals that the district court's "discretion is limited to choosing between [relief that insures] immediate compliance and [that which insures] prompt compliance."); Miller, Private Enforcement (pt. 2), supra note 89 , at 10,078 ("The question is not whether violations of the statute should be enjoined, but how they should be enjoined. Injunctive relief should be available almost automatically to remedy statutory violations, but the precise nature of the remedy should reflect 
Justice Stevens, in a dissenting opinion, contended that Congress had confined "the discretion of the federal judiciary much more narrowly than the [majority's] opinion suggest[ed]."101 Absent an "exceptional situation," which did not include this case, Congress imposed a "general rule of immediate cessation" of all discharges violating the statute. ${ }^{102}$ According to Justice Stevens, the majority's reading of the Clean Water Act was inconsistent with congressional intent and failed to give appropriate recognition to the public interest in halting ongoing statutory violations. ${ }^{103}$ Justice Stevens noted that "there [was] nothing in the [Glean Water Act] or [its] legislative history to suggest that Congress invited the federal courts to second-guess" Congress's decision to require permits for the discharge of pollutants into navigable waters. ${ }^{104}$

The implications of the Court's decision in Romero-Barcelo for future citizen suits seeking injunctive relief are not clear. First, it has been argued that, under the peculiar circumstances of this case, the discharges of pollutants by a federal facility without a permit did not violate the Clean Water Act. ${ }^{108}$ Second, even assuming a statutory violation, the decision may reflect only the courts' discretionary authority to choose among various options for achieving rapid compliance with the statute; it may not authorize the courts to permit violations to continue indefinitely. ${ }^{108}$ Third, the national security considerations involved in the Navy's testing program may have made the courts particularly reluctant to issue an injunction. ${ }^{107}$ The case could thus be narrowly lim-

the equities of the case."); Plater, supra note 92, at 593 ("The Court's holding appears to have been limited to the assertion of a discretion to permit noncompliance while defendants seek to end their violations, not a discretion to permit statutory noncompliance.") (footnote omitted).

101 Romero-Barcelo, 456 U.S. at 322 (Stevens, J., dissenting).

102 Id.

${ }^{103}$ See id. at 324-30. The majority argued that, "[i]n exercising their sound [equitable] discretion, courts of equity should pay particular regard for the public consequences in employing the extraordinary remedy of injunction." "Id. at 312 (quoting Railroad Comm'n v. Pullman, 312 U.S. 496, 500 (1941)).

104 See id. at 333 (Stevens, J., dissenting).

${ }^{105}$ See Farber, supra note 92, at 522-23 (contending that although the federal government is required to obtain a permit under the Clean Water Act, discharges by federal facilities lacking a permit are not unlawful); Plater, supra note 92, at $594 \mathrm{n} .327$ ("[T] $]$ he lack of a permit did not necessarily constitute statutory noncompliance."). But see 33 U.S.C. $§ 1323(\mathrm{a})(2)(\mathrm{A})$ (Each entity associated with the federal government that is engaged in discharging pollutants must comply with any requirement respecting permits "to the same extent as any nongovernmental entity.").

${ }^{108}$ See Romero-Barcelo, 456 U.S. at 315 ("[The district court] temporarily, not permanently, allowed the Navy to continue its activities without a permit.").

${ }^{107}$ See Barcelo v. Brown, 478 F. Supp. 646, 707-08 (D.P.R. 1979), rev'd sub nom. Romero-Barcelo v. Brown, 643 F.2d 835 (1st Cir. 1981), rev'd sub nom. Weinberger v. Romero-Barcelo, 456 U.S. 305 (1982); of. Weinberger v. Catholic Action, 454 U.S. 139 (1981) (holding that the government need not prepare an environmental im- 
ited to its facts.

The rationale behind the Court's decision, and the values and objectives the majority and dissenting justices sought to promote in Romero-Barcelo, are clearer. The majority opinion's emphasis on the broad equitable powers of trial court judges reflects a belief that it is appropriate, absent a clear congressional prohibition, ${ }^{108}$ for the courts to seek a practical accommodation of the interests of the two parties to the dispute, without imposing undue hardship on either party. ${ }^{109}$

Justice Stevens, on the other hand, implicitly recognized that the majority's decision could detract from the legitimacy of the statutory scheme of water pollution control. The Court's opinion vested control of the decision to abate statutory violations in the federal courts, rather than in the better-informed agency charged with implementing the Glean Water Act, the EPA. ${ }^{110}$ The decision also detracted from the legitimacy of the federal pollution control program by creating the possibilities of inconsistent enforcement, which would give rise to a perception of unfairness, ${ }^{111}$ and of uncertainty as to the consequences of statu-

pact statement under section 102(2)(C) of the National Environmental Policy Act, 42 U.S.C. $\S 4332(2)(C)$ (1982), with respect to a nuclear weapons facility because of the possibility of releasing classified information).

108 See 456 U.S. at 313. According to the majority:

"[T] he comprehensiveness of this equitable jurisdiction is not to be denied or limited in the absence of a clear and valid legislative command. Unless a statute in so many words, or by a necessary and inescapable inference, restricts the court's jurisdiction in equity, the full scope of that jurisdiction is to be recognized and applied."

Id. at 313 (quoting Porter v. Warner Holding Co., 328 U.S. 395, 398 (1946)).

${ }_{109}$ See, e.g., id. at 312 ("Where plaintiff and defendant present competing claims of injury, the traditional function of equity has been to arrive at a 'nice adjustment and reconciliation' between the competing claims .....") (quoting Hecht Co. v. Bowles, 321 U.S. 321, 329 (1944)); id. at 316 (The Clean Water Act "contemplates the exercise of discretion and balancing of equities."); $i d$. at 320 ("The exercise of equitable discretion, which must include the ability to deny as well as grant injunctive relief, can fully protect the range of public interests at issue."); see also Furrow, Governing Science: Public Risks and Private Remedies, 131 U. PA. L. REv. 1403, 1436-37 (1983):

The equitable powers available to a judge superintending complex public actions provide the possibility of flexible remedies . . . These powers ... draw upon a tradition in tort law which recognizes the value of conditional injunctions and flexible supervisory controls over hazardous activities, upon an emerging consensus on the range of powers available to the trial judge, and upon a recognition that a process of negotiation is occurring.

110 See Romero-Barcelo, 456 U.S. at 324, 325 \& nn.4-5, 333-34 (Stevens, J., dissenting).

111 See id. at $330 \mathrm{n} .11$ (Stevens, J., dissenting) ("Important national goals would be frustrated by a regime of discretion that 'produce[d] different results for breaches of duty in situations that cannot be differentiated in policy." ") (quoting Morgane v. State Marine Lines, 398 U.S. 375, 405 (1970), quoted in Albemarle Paper Co. v. Moody, 422 U.S. 405,417 (1975)) (footnotes omitted). 
tory violations. ${ }^{112}$ Finally, whereas the EPA is subject to executive and legislative overview, the federal courts are not politically accountable as decisionmakers and do not necessarily represent the prevailing community views. ${ }^{113}$ Furthermore, Justice Stevens charged, the majority had granted "an open-ended license to federal judges to carve gaping holes in a reticulated statutory scheme designed by Congress to protect precious natural resources."114 The Court's opinion demonstrated "[a] disregard of the respective roles of the three branches of government,"115 and an undercutting of respect for "the proper allocation of lawmaking responsibilities in our Government."116 Justice Stevens objected to the decision, therefore, because it flew in the face of the separation of powers doctrine, ${ }^{117}$ one of the foremost guarantees of individual liberty under our system of government.

If the Romero-Barcelo opinion is given a broad reading, authorizing federal district courts to refuse to enjoin ongoing statutory violations, ${ }^{118}$ then Justice Stevens' dissent is compelling. The dissenting Jus-

112 See supra text accompanying note 68.

11 See Romero-Barcelo, 456 U.S. at 333-35 (Stevens, J., dissenting).

114 Id. at 323. Justice Stevens concluded that "[t]he discretion exercised by the District Court in this case was wholly at odds with the intent of Congress in enacting [the Clean Water Act]." Id. at 324.

115 Id. at 333.

116 Id. at 335 (footnote omitted).

${ }^{117}$ See Plater, supra note 92 , at 588-92 (Judicial refusal to enforce valid statutes against a particular defendant "invades the core function of the legislature.").

118 The courts' equitable discretion to deny injunctive relief is narrower in certain suits brought by the government than it is under the citizen suit provisions. For example, the Administrator of the EPA is authorized by the Clean Air and Water Acts, RCRA, and CERCLA to seek a court order immediately restraining activities presenting an imminent hazard to health or the environment. See 42 U.S.C. $\$ 7603$ (a); 33 U.S.C. $\S 1364($ a); 42 U.S.C.A. $\$ 6973$ (a) (West 1983 \& Supp. 1985); 42 U.S.C. $\S 9606(a)$. The courts have demonstrated a much greater willingness to issue abatement orders at the EPA's request under these imminent hazard provisions, which reflect a "rule of immediate cessation," Romero-Barcelo, 456 U.S. at 317, than the Supreme Court thought appropriate under the citizen suit provisions. The imminent hazard provision of RCRA requires only that the EPA convince the court that certain activities "may present an imminent and substantial endangerment to health or the environment." 42 U.S.C.A. § 6973(a) (West 1983 \& Supp. 1985) (emphasis added). Several courts have held that the EPA need not prove either the lack of an adequate remedy at law or the threat of irreparable injury as a prerequisite for injunctive relief under the imminent hazard provisions. These provisions exhibit "an express statutory command giving the EPA an injunctive remedy. Congress chose to enhance the courts' traditional equitable powers in order to protect the public and the environment." United States v. Waste Indus., Inc., 734 F.2d 159, 168 (4th Cir. 1984) (citing United States v. Price, 688 F.2d 204, 211 (3d Cir. 1982)). As the Third Circuit has noted:

By enacting the endangerment provisions of [the Resource Conservation and Recovery Act and the Safe Drinking Water Act] Congress . . . [has] enhanced the courts' traditional equitable powers by authorizing the issuance of injunctions when there is but a risk of harm, a more lenient standard than the traditional requirement of threatened irreparable harm. 
tice's views become even more persuasive in light of the Court's decision one year earlier in City of Milwaukee $v$. Illinois. ${ }^{119}$ In holding that federal common-law nuisance actions had been preempted by the enactment of the Clean Water Act, the majority relied on the same arguments concerning the need to promote legitimacy and protect the separation of governmental powers advanced by Justice Stevens in Romero-Barcelo; the Milwaukee court, however, used these concerns to narrow the range of private remedies under federal law. There appears to be no reason not to implement those same values in a case, like $R o-$ mero-Barcelo, where they support the enlargement of private statutory remedies.

\section{B. Implied Statutory Remedies}

Although the citizen suit provisions do not authorize the recovery of damages, private plaintiffs have sought monetary relief ${ }^{\mathbf{1 2 0}}$ on the theory that the courts should find an implied private cause of action to enforce the pollution control statute at issue and to remedy harm caused by a violation of that statute. ${ }^{121}$ The Supreme Court held in Middlesex County Sewerage Authority v. National Sea Clammers Association ${ }^{122}$ that no such implied right of action exists under either the

United States v. Price, 688 F.2d 204, 211 (3d Cir. 1982) (citation omitted).

119451 U.S. 304 (1981). For a detailed discussion of this case, see infra text accompanying notes 199-277.

${ }_{120}$ Litigants have also sought injunctive relief on an implied private right of action theory where they have failed to comply with certain procedural requirements of the citizen suit provisions. See, e.g., 33 U.S.C. $\$ 1365(\mathrm{~b})(1)$ (The plaintiff must provide 60 days prior "notice of the alleged violation to the [EPA], . . . the State in which the alleged violation occurs, . . a and to any alleged violator."); Middlesex County Sewerage Auth. v. National Sea Clammers Ass'n, 453 U.S. 1, 6 (1981) (The plaintiffs brought suit alleging jurisdiction independent of the citizen suit provision after failing to comply with the notice requirement.); Reeger v. Mill Serv., Inc., 593 F. Supp. 360, 363 (W.D. Pa. 1984) (The plaintiffs sought to bring suit under the Givil Rights Acts as an alternative to the citizen suit provisions of the Clean Air Act and RCRA.).

Plaintiffs alleging the existence of an implied private right of action for damages or injunctive relief have not relied, for the most part, on the citizen suit provision as a basis for the court's jurisdiction. Instead, they have relied upon the general federal question statute, 28 U.S.C. $\S 1331$ (1982). See, e.g., National Sea Clammers, 453 U.S. at 7.

121 In recent years, the Supreme Court has repeatedly addressed the "seemingly simple question," "[w]hen should a person injured by a violation of federal law be allowed to recover his damages in a federal court?" Middlesex County Sewerage Auth. v. National Sea Clammers Ass'n, 453 U.S. 1, 22 (1981) (Stevens, J., concurring in part and dissenting in part). Recent cases in which the Court has faced this question include California v. Sierra Club, 451 U.S. 287 (1981); Universities Research Ass'n v. Coutu, 450 U.S. 754 (1981); Transamerica Mortgage Advisors, Inc. v. Lewis, 444 U.S. 11 (1979); Touche Ross \& Co. v. Redington, 442 U.S. 560 (1979); and Cannon v. University of Chicago, 441 U.S. 677 (1979).

122453 U.S. 1 (1981). 
Glean Water Act ${ }^{\mathbf{1 2 3}}$ or the Marine Protection, Research, and Sanctuaries Act of 1972. ${ }^{124}$

Although the Supreme Court had previously formulated a fourpart test for determining whether a court should infer a private right of action from a federal statute, ${ }^{\mathbf{1 2 5}}$ the Court found it unnecessary to apply all four parts of the test in National Sea Clammers, claiming that "[t]he key to the inquiry is the intent of the Legislature." ${ }^{126}$ The Clean Water Act and the Marine Protection, Research, and Sanctuaries Act contain "unusually elaborate enforcement provisions," EPA's authority to compel future compliance through the issuance of an administrative compliance order or through a civil action in federal district court, as well as the government's authority to seek civil or criminal fines and imprisonment for criminal violations. ${ }^{128}$ In addition, the two acts authorize private suits for injunctive relief, provided the alleged violation is covered by the applicable citizen suit provision and the plaintiff complies with all of the procedural prerequisites for citizen suits. ${ }^{129}$ Based on the varied and comprehensive nature of these remedial options, the Court concluded that Congress did not intend to authorize additional remedies for private enforcement of those statutes. ${ }^{130}$

The Court rejected the argument advanced by the Court of Appeals in favor of implying a private right of action. The Court of Appeals argued that the citizen suit provisions were intended to create a limited cause of action for "private attorneys general"-non-injured members of the public suing to promote the general welfare rather than

12s Accord Pawtuxet Cove Marina, Inc. v. Ciba-Geigy Corp., 21 Env't Rep. Cas. (BNA) 1393, 1394 (D.R.I. 1984); Love v. New York State Dep't of Envtl. Conservation, 529 F. Supp. 832, 838 (S.D.N.Y. 1981).

124 See 453 U.S. at 11, 13-18, 21 (discussing the Glean Water Act and the Marine Protection, Research, and Sanctuaries Act of 1972, 33 U.S.C. § 1401-1445 (1982)); see also California v. Sierra Club, 451 U.S. 287 (1981) (refusing to find an implied private right of action to enforce section 10 of the Rivers and Harbors Appropriation Act of 1899,33 U.S.C. $§ 402$ (1982)).

${ }^{25}$ Cort v. Ash, 422 U.S. 66 (1975). The four inquiries were first, whether the plaintiff is one of the class for whose special benefit the statute was enacted ("does the statute create a federal right in favor of the plaintiff?"); second, whether there is "any indication of legislative intent, explicit or implicit, either to create such a remedy or to deny one"; third, whether an implied private remedy is consistent with the purposes of the statutory scheme; and fourth, whether the cause of action is in an area "traditionally relegated to state law, ... . so that it would be inappropriate to infer a cause of action based solely on federal law." Id. at 78 .

126453 U.S. at 13; see also id. at 17-18.

127 Id. at 13.

128 See, e.g., 33 U.S.C. § 1319.

129 See id. $\$ \S 1365,1415$.

130 See National Sea Clammers, 453 U.S. at 14. The plaintiffs in National Sea Clammers sought both injunctive relief and damages. See id. at 5. 
to redress their own injuries. ${ }^{131}$ An injured private party, the Court of Appeals concluded, had an alternate basis for suit, namely, general federal question jurisdiction, ${ }^{\mathbf{1 3 2}}$ coupled with the citizen suit provision of the Clean Water Act, which saves or preserves rights "under any statute or common law to seek enforcement of any effluent standard or limitation."133 The Supreme Court responded that the Court of Appeals' distinction between non-injured and injured plaintiffs was invalid, since non-injured plaintiffs lack standing to sue, and, therefore, the statutory citizen suit provisions apply only to injured plaintiffs. Accordingly, there was no basis for inferring an additional right of action for this same group of plaintiffs. ${ }^{134}$ In response to the Court of Appeals' reliance on the "savings clause" of the. Glean Water Act's citizen suit provision, the Court reasoned that although the savings clause preserves additional rights under "any statute," Congress did not mean to include the Clean Water Act itself within that phrase. Thus, the savings clause preserves only substantive rights arising under statutes other than the Clean Water Act. ${ }^{138}$

131 National Sea Clammers Ass'n v. City of New York, 616 F.2d 1222, 1226-27 (3d Cir. 1980), vacated sub nom. Middlesex County Sewerage Auth. v. National Sea Clammers Ass'n, 453 U.S. 1, 15 (1981).

${ }_{132}$ See 28 U.S.C. $\S 1331$ (1982).

193 The savings clause in the Clean Water Act's citizen suit provision provides in full that "[n]othing in this section shall restrict any right which any person (or class of persons) may have under any statute or common law to seek enforcement of any effluent standard or limitation or to seek any other relief (including relief against the Administrator or a State agency)." 33 U.S.C. $\$ 1365($ e). The citizen suit provision of the Marine Protection, Research, and Sanctuaries Act is similar. See 33 U.S.C. $\S 1415(\mathrm{~g})(5)$.

134 See National Sea Clammers, 453 U.S. at 16.

135 See id. at 15-16. The Court supported its argument by citing the Senate Report on the 1972 amendments to the Clean Water Act, which stated that the savings clause " "would specifically preserve any rights or remedies under any other law." II. at 16 n.26 (quoting S. REP. No. 414, 92d Cong., 1st Sess. 81 (1971), reprinted in 1972 U.S. Code Cong. \& AD. News 3668, 3746) (emphasis added).

The Court proceeded to hold, however, that "any other law" did not include 42 U.S.C. $\S 1983$ (1982), which authorizes private persons to sue to redress the deprivation of any rights, privileges, or immunities secured by the Constitution or federal law by the actions of state officials in their official capacities. See National Sea Clammers, 453 U.S. at 19-21. The Court concluded that Congress did not intend to preserve a private right of action where the substantive violation alleged was a violation of the Clean Water Act, even if the remedy for that violation arose under another statute, such as 42 U.S.C. \& 1983. See National Sea Clammers, 453 U.S. at 20 n.31. The savings clauses applies, in other words, only where both the substantive right and the legal remedy arise under statutes other than the Clean Water Act.

The Court's analysis is not fully persuasive. The provisions of the 1971 Senate Report relied on by the Court indicate that Congress intended to "preserve any rights or remedies under any other law." S. REP. No. 414, 92d Cong., 1st Sess. 81 (1971), reprinted in 1972 U.S. Code Cong. \& AD. News 3668, 3746 (emphasis added). Thus, Congress arguably meant to preserve remedies created under statutes other than the Clean Water Act (including 42 U.S.C. $§ 1983$ ), even if the substantive violation 
The implications of the Court's decision in National Sea Clammers are much clearer than those stemming from the Romero-Barcelo decision. Because the Clean Air Act and RGRA contain the same array of governmental and private enforcement options as the Clean Water Act, it is almost certain that the Court would refuse to find an implied private right of action to enforce those two statutes. ${ }^{136}$ Although the remedial alternatives under CERCLA are not as extensive as those provided by the other three statutes, the existence of an express statutory provision authorizing private judicial and administrative remedies for the reimbursement of costs incurred in responding to releases of hazardous substances ${ }^{\mathbf{1 3 7}}$ probably indicates Congress's intent to limit private actions to those specified in the statute. ${ }^{238}$ The recognition of additional private rights of action might permit private plaintiffs to avoid the express conditions and limitations imposed on private cost recoveries included in GERGLA. ${ }^{139}$

alleged is a Clean Water Act violation. Moreover, the savings clause preserves not only the right under "any statute" to seek enforcement of any effluent standard or limitation, but also the right "to seek any other relief." 33 U.S.C. $\S 1365(\mathrm{e})$. This phrase appears to encompass a suit against a state official for violation of federal law under 42 U.S.C. $\S 1983$, even if the Court's narrow construction of the term "any statute"-that is, as preserving only the right to redress violations of statutes other than the Clean Water Act-is correct. The Court's holding on the section 1983 issue gives no effect whatever to the final clause of the savings provision. Courts should avoid interpretations that render portions of the statutory language meaningless. See, e.g., Pinole Point Properties, Inc. v. Bethlehem Steel Corp., 596 F. Supp. 283, 289-90 (N.D. Cal. 1984) (rejecting the defendant's statutory interpretation of CERCLA, because "statutes should be read to avoid surplusage"). Nevertheless, the lower courts have applied the reasoning of National Sea Clammers to private actions alleging violations of other federal pollution control statutes. See, e.g., Garcia v. Cecos Int'l, Inc., 761 F.2d 76, 82-83 (1st Cir. 1985). For suggestions that private plaintiffs may still be able to employ civil rights causes of action to redress violations of some federal pollution control statutes, see J. Bonine \& T. MCGarity, supra note 89, at 986. Cf. Sunstein, supra note 66, at 427-28 (arguing that the presumption against preemption of section 1983 should not apply when Congress has expressly created independent private causes of action).

${ }_{136}$ See Reeger v. Mill Serv., Inc., 593 F. Supp. 360, 361-63 (W.D. Pa. 1984); Miller, Private Enforcement (pt. 2), supra note 89, at 10,322; Trauberman, Common Law Nuisance in Hazardous Waste Litigation: Has it Survived Milwaukee II?, 13 ENVTL. L. REP. 10,043, 10,045 (1983). The result would almost certainly be the same under the Clean Air Act, since the Court relied on the legislative history of that Act's citizen suit provision-on which the Clean Water Act provision was modeled-to support its holding in National Sea Clammers. See 453 U.S. at 17 n.27.

137 See 42 U.S.C. §§ 9607(a)(1-4)(B), 9611-9612.

138 There would appear to be no basis for recognizing an implied private statutory remedy under CERCLA for personal injury or property damage, although commonlaw remedies for such injuries may still be available. See infra notes 495-523 and accompanying text.

139 For example, private cost recovery against a responsible party in federal court is appropriate only for "costs of response incurred . . consistent with the national contingency plan." 42 U.S.C. $\$ \$ 9607(a)(B), 9611(a)(2)$. The national contingency plan, issued by the EPA, provides guidance on the appropriate methods of hazardous 
The Court's decision in National Sea Clammers is also more consistent with the values of legitimacy, individual liberty, and efficiency than the decision in Romero-Barcelo. For example, the opinion in $\mathrm{Na}$ tional Sea Clammers reflects a greater concern for adherence to the separation of powers doctrine. The Court expressed its reluctance, absent strong evidence of a contrary congressional intent, to read into the statute remedies not expressly provided by the legislature. ${ }^{140}$ If Congress makes it clear "that implied private actions are not contemplated, the courts are not authorized to ignore this legislative judgment."141 The Court's decision can be viewed, then, as an attempt to enhance individual liberty by insuring that no one branch of the federal government oversteps the bounds of its constitutional authority. ${ }^{\mathbf{1 4 2}}$

The majority opinion also appears to reflect the conviction that Congress adopted the package of remedial options that it felt would produce the most efficient implementation of the statute's objectives. The Court may have feared that recognizing supplemental remedies not sanctioned by Congress would result in excessive (and unproductive) or duplicative (and wasteful) enforcement efforts. ${ }^{143}$

Although the Court in National Sea Clammers did not justify its holding by an express reference to the value of legitimacy, its decision,

waste site cleanup. See id. $\S 9605$.

140 See National Sea Clammers, 453 U.S. at 14-15.

141 Id. at 18. The dissenting Justices, however, seem to have the better argument concerning the disposition of the issue concerning 42 U.S.C. $\S 1983$ (1982), see supra note 135, at least in terms of adherence to the explicit terms of the statute. See 453 U.S. at $27-31$; $f$. supra note 135 (arguing that the Court misinterpreted the savings clause of the citizen suit provision of the Clean Water Act).

${ }_{142} C f$. Stewart \& Sunstein, supra note 66, at 1207 ("[P]rivate rights of action may usurp the agency's responsibility for regulatory implementation, decrease legislative control over the nature and amount of enforcement activity, and force courts to determine in the first instance the meaning of a regulatory statute."); id. at 1221 ("By enlisting new enforcement resources, courts that create private remedies substantially affect the content of regulatory policy-a task properly reserved for the political branches."); $i d$. at 1317 (describing the "formalist thesis" that courts improperly invade congressional authority to determine the substance and implementation of administrative programs when they create remedies not provided in the statute itself).

143 See National Sea Clammers, 453 U.S. at 14-15, 21; F. ANDERSoN, D. MANDELKer \& A. TARLOCK, supra note 60, at 446, 659. See generally Landes \& Posner, The Private Enforcement of Law, 4 J. LeGal STud. 1 (1975) (Private enforcement of law results in overenforcement where substantial investment in apprehension and conviction of offenders is necessary.). Centralized governmental enforcement is not necessarily more efficient, however, than a system permitting supplemental citizen enforcement. See W. RodGers, supra note 74, at 76 (1977) (listing the following as justifications for citizen enforcement: private enforcement is less costly than public enforcement; private enforcers are in a better position to weigh the costs and benefits of a particular initiative; total resources devoted to enforcement are augmented; and competition from the private sector sharpens the response of public officials); Stewart \& Sunstein, supra note 66, at 1215 ("Private rights of action . . . do not divert limited agency resources from other violations that may be more important."). 
nevertheless, promotes the legitimacy of the Clean Water Act's enforcement program in several ways. Agency enforcement initiatives, unlike private citizen enforcement, are subject to congressional oversight mechanisms such as the appropriations process. Accordingly, the legislature can take steps to ensure that the agency does not enforce the statute in a manner contrary to congressional intent. ${ }^{144}$ Some perceive administrative agencies as possessing greater factfinding and policymaking competence than the courts in technically and scientifically complex areas such as pollution control. ${ }^{145}$ Finally, a prohibition on implied rights of action may result in a more coordinated and consistent enforcement program than would otherwise be the case. ${ }^{146}$ In light of its tendency to promote legitimacy, individual liberty, and efficiency, the Court's implied right of action holding in National Sea Clammers is consistent with the values implicitly reflected in the Constitution and in congressional attempts to control pollution. ${ }^{147}$

14 See R. STEWART \& J. KRIER, supra note 78, at 106; Stewart \& Sunstein, supra note 66, at 418; Sunstein, supra note 66, at 1209, 1227-28, 1290-91, 1291 n.404. Congress could amend the citizen suit provisions to counter unintended private enforcement efforts, but this kind of legislative action may be more difficult to accomplish than some of the more informal techniques for legislative oversight of administrative action, such as committee hearings.

${ }^{148}$ The majority of the Court in City of Milwaukee v. Illinois, 451 U.S. 304 (1981), noted that the complex nature of water pollution control makes it a particularly appropriate area for the exercise of administrative expertise. See id. at 325 . For an examination of the appropriateness of agency action in areas involving complex scientific or technical matters, see R. Pierce, S. Shapiro \& P. Verkuil, Administrative LAW AND PROCEDURE \& 6.4.12, at 272; Stewart \& Sunstein, supra note 66, at 120809, 1218, 1293; Sunstein, supra note 66, at 416-17. But cf. Furrow, supra note 109, at 1422-23 (Public participation in policymaking concerning scientifically complex issues can increase the information available to decisionmakers.). To the extent that a bar on citizen enforcement reduces public participation in the advancement of statutory objectives, such a bar may reduce the legitimacy of the statutory program. Cf. Stewart \& Sunstein, supra note 66, at 1294 (arguing that a private right of enforcement may be justifiable as a means of asserting public values).

146 See Stewart \& Sunstein, supra note 66, at 1292-93 (noting that private rights of action may "impair an agency's ability to harmonize potentially conflicting statutory provisions and to negotiate with regulated firms and other affected interests in order to establish a workable and consistent regulatory system") (footnotes omitted); see also Walls v. Waste Resource Corp., 761 F.2d 311, 317 (6th Cir. 1985) (explaining that the notice requirements for citizen suits under RCRA serve to give the EPA the opportunity "to develop uniform interpretations of complex environmental standards" by limiting the number of private lawsuits).

147 If, however, the Court's holding promotes one value while impairing another, it is necessary to determine which of the values the legislature deemed more important. See, e.g., Stewart \& Sunstein, supra note 66, at 1216 (referring to a "maximum enforcement approach," under which "the values of political control, specialization, and centralization are considered less important than maximizing private participation in the enforcement process"); id. at 1226-27 (implied rights of action can be defended as a means of overcoming agency failure to implement a regulatory program because of the "capture" of the agency by regulated entities). Even if a particular interpretation of an 


\section{Federal Common-Law Remedies}

\section{The Application of Federal Common Law in Environmental Litigation Before Milwaukee I}

Early in the twentieth century, the Supreme Court relied on federal common law in environmental litigation for two purposes: to protect one state's natural resources from invasion by another state, and to avoid or resolve disputes between the states. ${ }^{148}$ One early example of a case in which these two purposes coalesced is Missouri $v$. Illinois. ${ }^{149}$ Missouri, in its petition to the Supreme Court, ${ }^{150}$ alleged that the Sanitary District of Chicago threatened to discharge sewage into a ditch running to the Des Plaines and Mississippi Rivers, resulting in the pollution of water used by Missouri residents. ${ }^{151}$ Missouri requested that the Court enjoin the Sanitary District's discharges as a nuisance. ${ }^{\mathbf{1 0 2}}$

ambiguous statute promotes values normally favored by the legislature, a court should be reluctant to choose that interpretation if it results in a conflict with the values of the Constitution. See supra text accompanying note 87. Despite its arguable legitimacy, for example, the prohibition on implied rights of action for compensatory relief can be attacked as inconsistent with one of the components of individual liberty, because it fails to protect personal health and property rights from the imposition of harm by third persons. This defect, however, should not be dispositive if the statute preserves common-law remedies for personal injury and property damage. A statutory scheme that eliminates these remedies while providing no statutory substitute, on the other hand, is highly vulnerable to an attack as inconsistent with the value of individual liberty and violative of the due process clause. See infra notes 329-48 and accompanying text.

148 In 1938 the Supreme Court decided Erie R.R. v. Tompkins, 304 U.S. 64 (1938), holding that "[t]here is no federal general common law" in diversity cases. Id. at 78. The Court subsequently acknowledged that, despite its decision in Erie, "there are enclaves of federal judge-made law which bind the states." Banco Nacional de Cuba v. Sabbatino, 376 U.S. 398, 426 (1964). One commentator has listed the following areas in which the Supreme Court has recognized the propriety of invoking this "specialized" body of common law: issues involving disputes between states over interstate resources or protection of a state's sovereign rights; issues related to the operations of federal statutory law or to the furtherance of federal policy; issues arising under maritime law; and issues of international law. See Comment, supra note 90, at 314-15 \& nn.89-98. The development of federal common law is therefore appropriate where it is necessary to protect "uniquely federal interests," see Texas Indus., Inc. v. Radcliff Materials, Inc., 451 U.S. 630,640 (1981) (Federal courts have the power to formulate federal common law in two limited categories: those in which a federal rule of decision is necessary to protect federal interests, and those in which Congress has given the courts the power to develop substantive law.), or where the need for a uniform rule of decision is apparent. See Illinois v. City of Milwaukee, 406 U.S. 91, 105 n.6 (1972); Sabbatino, 376 U.S. at 398,427 n.25.

148180 U.S. 208 (1901) (demurrer overruled), 200 U.S. 496 (1906) (decision on the merits dismissing Missouri's suit without prejudice).

${ }_{100}$ Missouri invoked the original jurisdiction of the Supreme Court: "In all Cases ... in which a State shall be [a] Party, the supreme Court shall have original jurisdiction." U.S. CoNST. art. III, $\S 2$, cl. 2.

${ }^{151}$ Missouri v. Illinois, 180 U.S. at 212-13.

$152 I d$. at 215 . A public nuisance is an unreasonable interference with a right 
The Court refused to sustain Illinois' demurrer, holding that the federal government had a duty to provide Missouri with a remedy to protect the health and comfort of its citizens. ${ }^{153}$ This duty was fulfilled through the constitutional provision authorizing the Supreme Court to take jurisdiction over the dispute. ${ }^{154}$ The Missouri decision thus supports the proposition that the federal government cannot leave a state without any means of protecting its residents against harm by outsiders.

Several years later, in Georgia v. Tennessee Copper Co., ${ }^{165}$ the Court affirmed the notion that the federal government is required to provide a means of resolving disputes in which one state or its citizens allegedly harm the natural resources of another. The Court found that each state, in its quasi-sovereign capacity, has an interest in the protection of natural resources within its domain, ${ }^{158}$ and that "such demands must be recognized" when the grounds alleged by a state are proven. ${ }^{157}$

These cases reflect the Court's willingness to invoke a judicially created federal rule of decision when basic interests of federalism are at stake. ${ }^{158}$ When the resources of one state are threatened by pollutant emissions from a source located in another state, a federal resolution must be made available to protect the interests of one state from encroaching on those of another. Such an encroachment threatens the in-

common to the general public, such as an interference with the public health, safety, peace, comfort, or convenience. RESTATEMENT (SECOND) OF TORTS $§ 821 \mathrm{~B}$ (1979).

${ }_{103}$ See Missouri v. Illinois, 180 U.S. at 241.

154 See id.

186206 U.S. 230 (1907).

186 See id. at 237.

${ }^{167}$ See id. The Court continued:

When the States by their union made the forcible abatement of outside nuisances impossible to each, they did not thereby agree to submit to whatever might be done. They did not renounce the possibility of making reasonable demands on the ground of their still remaining quasi-sovereign interests; and the alternative to force is a suit in this court.

Id. (citing Missouri v. Illinois, 180 U.S. 208, 241 (1901)).

${ }_{158}$ Between the Supreme Court's decision in Illinois v. City of Milwaukee, 406 U.S. 91 (1972) (Milwaukee $I$, and its decision in City of Milwaukee v. Illinois, 451 U.S. 304 (1981) (Milwaukee II), the lower courts relied on these federalism concerns to support the application of federal common law to interstate pollution disputes. See, e.g., City of Evansville v. Kentucky Liquid Recycling, Inc., 604 F.2d 1008, 1017-18 (7th Cir. 1979) (permitting a municipal corporation to sue in federal court for damages arising from interstate waterway pollution), cert. denied, 444 U.S. 1025 (1980); Stream Pollution Control Bd. v. United States Steel Corp., 512 F.2d 1036, 1039-41 (7th Cir. 1975) (granting federal jurisdiction on a complaint based on federal common law by a state Stream Pollution Control Board seeking to abate river pollution); $c f$. Committee for the Jones Falls Sewage Sys. v. Train, 539 F.2d 1006, 1008-09 (4th Cir. 1976) (Absent allegations of harm extending beyond the boundaries of the state in which the source is located, complaint invoking the federal common law fails to state a claim on which relief can be granted.). The Supreme Court decisions in the 1972 and 1981 Milwaukee cases are discussed infra notes 175-285 and accompanying text. 
tegrity of the invaded state's sovereignty, and thereby threatens individual liberty by diminishing the capacity of the invaded state's citizens for self-determination. ${ }^{169} \mathrm{~A}$ federal resolution is also required to prevent conflict between the states and to promote the peaceful accommodation of disputes. ${ }^{180}$

Throughout the first half of the century, the Court, in exercising its original jurisdiction, periodically resorted to federal common law to resolve disputes between states over the conflicting use of natural resources. ${ }^{\mathbf{1 6 1}}$ In 1971, however, the Court seemed to signal a departure from this practice, at least where one state sued the citizens of another state rather than the second state itself. In Ohio v. Wyandotte Chemical Corp., ${ }^{182}$ Ohio sought to invoke the Court's original jurisdiction to abate an alleged public nuisance caused by two corporations located in Michigan. ${ }^{163}$ The defendants dumped mercury into streams that led into Lake Erie, allegedly damaging the fish, wildlife, and vegetation of Lake Erie and harming Ohio citizens. ${ }^{164}$ Although the Court conceded that it had jurisdiction over the controversy, ${ }^{165}$ it declined to exercise it on the grounds that the case did not involve any "important problems of federal law"168 and that the Court, structured to perform as an appellate tribunal, was ill-equipped to play the role of factfinder during a trial. ${ }^{167}$

169 See supra note 71 and accompanying text.

${ }^{160}$ See Fort, The Necessary Demise of Federal Common Law Nuisance, 12 Loy. U. CHI. L.J. 131, 138-39 (1981); Comment, supra note 90, at 319. Some writers have asserted that the application of federal common law to resolve such interstate disputes is constitutionally compelled. See, e.g., Monaghan, The Supreme Court, 1974 Term -Foreward: Constitutional Common Law, 89 HARv. L. REv. 1, 13-14 (1975). The propriety of applying state common law to an interstate pollution dispute is considered infra notes 400-82 and accompanying text.

181 See, e.g., Nebraska v. Wyoming, 325 U.S. 589 (1945); New Jersey v. City of New York, 283 U.S. 473 (1931); North Dakota v. Minnesota, 263 U.S. 365 (1923); New York v. New Jersey, 256 U.S. 296 (1921); Kansas v. Colorado, 206 U.S. 46 (1907).

162401 U.S. 493 (1971).

183 A third corporate defendant did business in Ontario, Canada. Id. at 494.

104 Id. at 495.

185 See id. at 495-96 (citing New Jersey v. City of New York, 283 U.S. 473 (1931), enforced, 284 U.S. 585 (1931), modified, 290 U.S. 237 (1933), construed, 296 U.S. 259 (1935); New York v. New Jersey, 256 U.S. 296 (1921); Georgia v. Tennessee Copper Co., 206 U.S. 230 (1907); and Missouri v. Illinois, 180 U.S. 208 (1901), 200 U.S. 496 (1906) (decision on the merits), as cases in which the Supreme Court exercised jurisdiction over interstate nuisance disputes).

166 Wyandotte, 401 U.S. at 504.

167 See id. at 498. The Court denied that it had any "special competence in dealing with the numerous conflicts between States and nonresident individuals that raise no serious issues of federal law." Id. The Court characterized its past attempts at settling disputes regarding interstate air and water pollution as "anything but smooth." Id. at 501. These attempts illustrated "the sense of futility that has accompanied this 
The Court noted that its refusal to hear the case left the plaintiff without a federal judicial forum. Ohio could not sue in federal district court based on federal question jurisdiction ${ }^{168}$ because, "[s]o far as it appears from the ... record, an action such as this, if otherwise cognizable in federal district court, would have to be adjudicated under state law."169

Shortly before the Court issued its decision in Wyandotte, the Court of Appeals for the Tenth Circuit, in Texas v. Pankey, ${ }^{170}$ had come to the opposite conclusion concerning a state's ability to sue in federal district court. Texas sued eight New Mexico ranchers in federal district court, seeking to enjoin them from using a pesticide to kill range caterpillars. ${ }^{171}$ Texas alleged that the pesticides were washed into the Canadian River system, impairing the water supplies of eleven Texas municipalities. ${ }^{172}$ The circuit court reversed the district court's dismissal, holding that the controversy arose under the laws of the United States and was therefore cognizable under the federal question statute. ${ }^{173}$ The court found that Texas had a right under federal common law to prevent the improper impairment of its environment from sources outside the state. ${ }^{174}$ This result reflected the view enunciated throughout the first half of the century that without the ability to protect its resources from external harms, the very sovereignty of the state is threatened. Invoking the aid of the federal courts was one way for the state to achieve such protection.

\section{Milwaukee $I$ and Its Progeny}

Less than a year after the decision in Wyandotte, the Court ac-

Court's attempts to ... [deal] with the complex technical and political matters that inhere in all disputes of the kind at hand." Id. at 502.

${ }_{168}$ See 28 U.S.C. § 1331 (1982).

169 Wyandotte, 401 U.S. at 498 n.3 (citing Erie R.R. v. Tompkins, 304 U.S. 64 (1938)). The plaintiff could not proceed under diversity jurisdiction either, since 28 U.S.C. $\S 1332$ (1982) does not cover cases in which a state is a party. See 401 U.S. at 498 n.3.

170441 F.2d 236 (10th Cir. 1971).

171 Id. at 237.

172 Id. at 238.

173 See id. at 242 .

174 See id. at 240 (citing Georgia v. Tennessee Copper Co., 206 U.S. 230 (1907)). The court noted that the Supreme Court in Tennessee Copper had not discussed explicitly the source of a state's quasi-sovereign ecological rights, which was "only natural" since "the need for and existence of federal common law had not yet been recognized." Texas v. Pankey, 441 F.2d at 240 . Nevertheless, "the[se] right[s] apparently [were] regarded as having existence in the common law and as being entitled to remedy within common law principles." Id. The Supreme Court had also recognized in Tennessee Copper that the state's right of protection against pollution from outside sources was a "right of protection by a federal court." Id. 
cepted much of the Tenth Circuit's reasoning and overruled the Wyandotte decision in Illinois $v$. City of Milwaukee (Milwaukee I). ${ }^{175}$ Illinois sought to invoke the Court's original jurisdiction to enjoin an alleged public nuisance caused by the defendants' discharge of sewage into bordering Lake Michigan. ${ }^{176}$ Although the Court declined to exercise its original jurisdiction over the case, it found that Illinois could sue in federal district court. ${ }^{177}$ Relying on Texas v. Pankey, the Court concluded that the federal question statute ${ }^{178}$ covered claims founded upon federal common law as well as those of a statutory origin. ${ }^{179}$ Due to the enactment of the Federal Water Pollution Control Act, ${ }^{180}$ "federal, not state law controls the pollution of interstate or navigable waters."181 The remedies provided in federal statutes, however, are not necessarily the only federal remedies available. Where federal rights are concerned, federal courts sometimes fill gaps in federal statutory schemes. ${ }^{182}$ The Court stated that, "[w] $\mathrm{w}$ hen we deal with air and water in their ambient or interstate aspects, there is a federal common law."183 According to the Court, applying federal common law to abate a public nuisance in interstate or navigable waters was not inconsistent with the Federal

176406 U.S. 91 (1972). The background of the Milwaukee I litigation is described in detail in Comment, supra note 90, at 301-11. The Court purported simply to distinguish Wyandotte, stating that the result in that case "was based on the preoccupation of that litigation with public nuisance under Ohio law, not the federal common law which we now hold is ample basis for federal jurisdiction under 28 U.S.C. § 1331(a)." Milwaukee I, 406 at 102 n.3. Nine years later, however, the Court admitted that the 1972 Milwaukee decision had overruled the Court's statement in Wyandotte that Ohio's suit, if otherwise cognizable in federal district court, would have to be adjudicated under state law. See City of Milwaukee v. Illinois, 451 U.S. 304, 327 n.19 (1981).

${ }^{176}$ The defendants included four Wisconsin cities, the Sewerage Commission of the City of Milwaukee, and the Metropolitan Sewerage Commission of the County of Milwaukee. See 406 U.S. at 93.

177 See id. at 108.

17828 U.S.C. \& 1331 (1982).

178 See Milwaukee I, 406 U.S. at 98-101.

180 The Court's decision was issued prior to the enactment of the Federal Pollution Control Act Amendments of 1972, Pub. L. No. 92-500, 86 Stat. 816. The decision in Milwaukee I was therefore based upon a consideration of the Water Pollution Control Act of 1948, Pub. L. No. 80-845, 62 Stat. 1155 (current version at 33 U.S.C. $\S 1251-1376$ (1982)).

181406 U.S. at 102 (footnote omitted).

182 See id. at 103.

18s Id. (footnote omitted); see also id. at $107 \mathrm{n} .9$ (stating that federal common law is needed to provide a uniform standard in cases involving the improper impairment of a state's environmental rights by sources outside its domain); Stream Pollution Control Bd. v. United States Steel Corp., 512 F.2d 1036, 1039 (7th Cir. 1975) (interpreting Milwaukee $I$ as "authoriz[ing] the federal courts to fashion a federal common law of nuisance to resolve controversies involving the impairment of the environmental interests of one state by sources outside its domain"). 
Water Pollution Control Act. ${ }^{184}$ The Court added, however, that

new federal laws and new federal regulations may in time pre-empt the field of federal common law of nuisance. But until that comes to pass, federal courts will be empowered to appraise the equities of the suits alleging creation of a public nuisance by water pollution. ${ }^{\mathbf{1 8 5}}$

The Court based its decision in Milwaukee $I$ on several of the components of the values of individual liberty and accommodation. Protecting state sovereignty promotes individual liberty by facilitating selfdetermination and citizen participation in government. ${ }^{186}$ Quoting from Georgia v. Tennessee Copper Co., the Court in Milwaukee I recognized each state's " 'quasi-sovereign interests" " in protecting its natural resources from impairment by nuisances caused by sources outside the state. ${ }^{187}$ "[A] State with high water-quality standards may well ask that its strict standards be honored and that it not be compelled to lower itself to the more degrading standards of a neighbor."188 By asking the federal courts to apply federal common-law rules to abate external sources of harm, states are able to protect their interests. ${ }^{189}$

Resort to a body of federal common law in these circumstances also advances the related value of the accommodation of conflicting state interests. The Court recognized that as concern about the protection of natural resources grows, " more conflicting disputes, increasing assertions and proliferating contentions" " between states " 'would seem to be inevitable." "180 By permitting the initiation of suits under the federal common law, the Court encourages the resolution of such disputes by "peaceful means." 191 Accordingly, the Court declared that the

184 Milwaukee I, 406 U.S. at 104.

185 Id. at 107. The Court of Appeals in Texas v. Pankey made a similar statement concerning the possibility that the enactment of a comprehensive federal statute could affect the scope of the availability of federal common law. See 441 F.2d at 241.

${ }_{188}$ See supra note 71 and accompanying text.

${ }_{187}$ See 406 U.S. at 104 (quoting Georgia v. Tennessee Copper Co., 206 U.S. at 237). The Court referred twice to "the ecological rights of a State in the improper impairment of [its resources] from sources outside the State's own territory.' "Id. at 100 (quoting Texas v. Pankey, 441 F.2d at 240); see also Milwaukee I, 406 U.S. at 108 n.9 (quoting Texas v. Pankey, 441 F.2d at 241, for the proposition that a uniform standard is needed to deal with " the environmental rights of a State against improper impairment by sources outside its domain" "). The Court also quoted an earlier decision recognizing a state's " 'interest as quasi-sovereign in the comfort, health and prosperity of its [residents]. " Milwaukee I, 406 U.S. at 106 n.8 (quoting North Dakota v. Minnesota, 263 U.S. 365, 374 (1923)).

${ }^{188}$ Milwaukee I, 406 U.S. at 107.

189 See id. at 107-08.

190 Id. at 107 n.9 (quoting Texas v. Pankey, 441 F.2d at 241).

191 Id. at 107. 
development of federal common law is appropriate "where the controversy touches basic interests of federalism." 192

Finally, the use of federal common law in Milwaukee I provided a means for reconciling potential conflicts between federal and state interests. ${ }^{193}$ Contrary to its earlier position in Wyandotte, the Court in Milwaukee $I$ recognized a federal interest in controlling the pollution of interstate or navigable waters. ${ }^{194}$ More generally, the Court noted Congress's increasing concern, over a period of seventy years, ${ }^{195}$ with protecting the quality of the environment. ${ }^{186}$ Because of the "overriding federal interest in the need for a uniform rule of decision,"197 the Court held that the controversy between Illinois and Milwaukee should be resolved by applying federal common law. ${ }^{198}$

192 Id. at 105 n.6 (citing Banco Nacional de Cuba v. Sabbatino, 376 U.S. 398, 421-27 (1964)); accord D'Oench, Duhme \& Co. v. Federal Deposit Ins. Corp., 315 U.S. 447 (1942); C. Wright, The LAW OF Federal Courts 249 (2d ed. 1970). The Court's reference to the protection of "basic interests of federalism" echoes similar sentiments expressed in the earlier interstate pollution and resource allocation cases initiated by one state against another under the Court's original jurisdiction. See supra notes 148-61 and accompanying text; see also Note, Federal Common Law and Water Pollution: Statutory Preemption or Preservation?, 49 FordHAM L. REv. 500, 524-27 (1981) (discussing the protection of quasi-sovereign state interests in interstate disputes by federal common law).

193 See supra note 76 and accompanying text.

194 See 406 U.S. at 102. Nine years after the Court's decision in Milwaukee I, Justice Blackmun explained that the Milwaukee I Court had "recounted the history of federal interstate water quality legislation and suggested that the abiding federal interest in the purity of interstate waters justified application of federal common law." City of Milwaukee v. Illinois, 451 U.S. 304, 337 (1981) (Blackmun, J., dissenting).

${ }^{195}$ In 1899, Congress enacted the Rivers and Harbors Act, 30 Stat. 1121 (1899) (codified in scattered sections of 33 U.S.C.) to control obstructions in, and discharges of refuse matter into, navigable waters. In 1969, Congress passed the National Environmental Policy Act, Pub. L. No. 91-190, 83 Stat. 852 (1969) (codified at 42 U.S.C. $\S \S 4321-4347$ (1982)), which, among other things, requires agencies of the federal government to prepare environmental impact statements in connection with major federal actions significantly affecting the quality of the human environment. See 42 U.S.C. $\S 4332(2)(\mathrm{C})(1982)$.

${ }_{198}$ See Milwaukee I, 406 U.S. at 101-02. The Tenth Circuit in Texas v. Pankey also found that the use of federal common law must be recognized "as a basis for dealing in uniform standard with the environmental rights of a State against improper impairment by sources outside its domain." 441 F.2d at 241.

197 Milwaukee I, 406 U.S. at 105 n.6.

198 Following the Court's decision in Milwaukee I, the lower federal courts frequently resorted to the federal common law of nuisance to resolve environmental disputes, although they had difficulty defining the precise scope of that law. They disagreed, for example, on the need for the plaintiff to demonstrate interstate effects of pollution. Compare Ancarrow v. City of Richmond, 600 F.2d 443, 445 (4th Cir.) (Federal common law should not extend beyond interstate controversies in which a plaintiff seeks relief against an extraterritorial polluter.), cert. denied, 444 U.S. 992 (1979) and Committee for the Jones Falls Sewage Sys. v. Train, 539 F.2d 1006, 1008-09 (4th Cir. 1976) (Absent a clash of two states' interests, state law is adequate to resolve a controversy between two or more of that state's own citizens.) with Illinois v. Outboard Marine Corp., 619 F.2d 623, 628 (7th Cir. 1980) (Federal common law applies to "all 


\section{Milwaukee II}

Although the courts struggled after Milwaukee $I$ to define the scope of the federal common law of nuisance, many of the questions raised by Milwaukee $I$ became academic, at least in the area of water pollution control, in 1981, when the Supreme Court issued its decision in City of Milwaukee v. Illinois (Milwaukee II). ${ }^{199}$ After the Court's decision in Milwaukee I, Illinois refiled its complaint in federal district court, again seeking abatement under federal common law of the alleged public nuisance created by Milwaukee's sewage discharges into

federal waters, even tributaries of intrastate navigable waters. . . . Federal concern is not just in navigability but in the purity and quality of the waters."), vacated and remanded, 453 U.S. 917 (1981).

The post-Milwaukee $I$ decisions also disagreed on the question of who could bring an action under the federal common law of nuisance. Some courts and commentators, relying on the rationale that federal common law was needed to protect the conflicting interests of two or more states in the use of the same resource, took the view that only a state or one of its municipalities can invoke this body of law. See, e.g., Committee for Jones Falls, 539 F.2d at 1009; United States v. Lindsay, 357 F. Supp. 784, 794 (E.D.N.Y. 1973). This view, however, failed to take into account those situations in which federal common law is needed-regardless of whether a state invaded by pollution chooses to assert its "quasi-sovereign" interests-to protect the federal interest in the need for a uniform rule of decision. If the federal interest is sufficiently compelling, the use of federal common law is arguably appropriate, regardless of the identity of the party bringing suit. See Committee for Jones Falls, 539 F.2d at 1013-14; Note, Umbrella Equities: Use of the Federal Common Law of Nuisance to Catch the Fall of Acid Rain, 21 URB. L. ANN. 143, 163 (1981). But see Jackson v. Johns-Manville Sales Corp., 750 F.2d 1314 (5th Cir. 1985) (refusing to apply a federal common law of asbestos product liability where the dispute did not involve the rights and duties of states as discrete political entities).

In contexts other than environmental disputes, the Supreme Court has authorized the use of federal common law in suits brought by private parties, provided the case demands the protection of a unique federal interest. See, e.g., Textile Workers v. Lincoln Mills, 353 U.S. 448, 456-57 (1957) (Federal courts can fashion a body of federal common law for the enforcement of collective bargaining agreements.). Based on a similar analysis, several courts have permitted even private plaintiffs to bring a federal common-law nuisance action involving interstate waters because of the overriding federal interest in uniformity. See, e.g., National Sea Glammers Ass'n v. City of New York, 616 F.2d 1222, 1233 (3d Cir. 1980), rev'd on other grounds sub nom. Middlesex County Sewerage Auth. v. National Sea Clammers Ass'n, 453 U.S. 1 (1981); Byram River v. Village of Port Chester, 394 F. Supp. 618 (S.D.N.Y. 1975). The Supreme Court considers this issue to be unsettled. See National Sea Clammers, 453 U.S. at 11 n.17, 21. The final controversy over the scope of federal common law in environmental and resource allocation disputes is whether the prevailing plaintiff is limited to equitable relief or can also seek damages. The Supreme Court considers this to be an open question as well. See id.

${ }^{199} 451$ U.S. 304 (1981). The scope of the federal common law of nuisance would become significant again if Congress explicitly authorized its use in certain water pollution contexts. Several bills that would have that effect have been introduced, but none have been enacted yet. See, e.g., H.R. 6577, 97th Cong., 2d Sess. (1982). The implications of the Supreme Court's decision in Milwaukee II for other environmental statutes are discussed infra at notes 255-77 and accompanying text. 
Lake Michigan. ${ }^{200}$ The district court concluded that Illinois had proved the existence of a nuisance under the federal common law, and ordered the defendants to eliminate overflows from sewers ${ }^{201}$ that resulted in sewage discharges directly into Lake Michigan or into tributaries leading into the lake. ${ }^{202}$ The court also imposed effluent limitations on treated sewage discharges from two waste water treatment plants operated by the defendants. ${ }^{203}$ The Court of Appeals for the Seventh Circuit agreed that Illinois had proven the existence of a federal commonlaw nuisance, but it modified some of the effluent standards set by the district court. ${ }^{204}$ The appellate court held that the federal common law of nuisance had not been preempted by the enactment of the 1972 amendments to the Clean Water Act ${ }^{205}$ five months after Illinois filed its action in federal district court, ${ }^{206}$ and that compliance with a discharge permit issued under the Act ${ }^{207}$ was not a defense to a federal common-law action. ${ }^{208}$

The Supreme Court reversed, holding that no federal common-law remedy was available to Illinois in this case. ${ }^{209}$ The Court began its analysis by asserting that normally it is Congress, not the federal courts, that adopts the applicable law and policy in an area in which the federal government has the power to act. ${ }^{210}$ The federal courts are free to adopt a federal rule of decision only in those " $f e w$ and restricted" " instances in which Congress has failed to act. ${ }^{211}$ Once Congress addresses a question previously governed by federal common law, "the need for such an unusual exercise of lawmaking by federal courts disappears."212 Thus, in determining whether an identifiable body of federal common law applies to a particular question, the issue is not whether Congress has affirmatively proscribed the use of that law, but simply "whether the legislative scheme 'spoke directly to [the] ques-

${ }^{200}$ Milwaukee II, 451 U.S. at 310.

201 Id. at 311.

$202 I d$. at 308-09.

${ }^{203}$ Id. at 311-12.

204 See Illinois v. City of Milwaukee, 599 F.2d 151, 176-77 (7th Cir. 1979), rev'd, 451 U.S. 304 (1981).

${ }^{205}$ Pub. L. No. 92-500, 86 Stat. 816 (1972).

206 See Milwaukee II, 451 U.S. at 310.

207 The National Pollutant Discharge Elimination System ("NPDES") permit program is authorized by section 402 of the Clean Water Act, 33 U.S.C. $§ 1342$. Permits are issued either by the EPA or by a state agency to which the EPA has delegated permit authority. See id. $\S 1342$ (b).

${ }^{208}$ See Illinois v. City of Milwaukee, 599 F.2d 151, 163 (7th Cir. 1979), rev'd, 451 U.S. 304 (1981).

${ }^{208}$ See Milwaukee II, 451 U.S. at 332.

210 See id. at 312-13.

211 See id. at 313 (quoting Wheeldin v. Wheeler, 373 U.S. 647, 651 (1963)).

212 Id. at 314. 
tion." "213 Applying this test, the Court concluded that when Congress enacted the 1972 amendments to the Clean Water Act, ${ }^{214}$ it "occupied the field through the establishment of a comprehensive regulatory program supervised by an expert administrative agency."215

The Court found that "the problem of effluent limitations has been thoroughly addressed through the administrative scheme established by Congress." ${ }^{218}$ As a result, federal courts were precluded from using the federal common law to impose on dischargers effluent limitations more stringent than those established by the EPA under the statute. ${ }^{217}$ The statutory scheme lacked any "interstices" to be filled by federal common law. ${ }^{218}$ Moreover, the Court felt that the use of federal common law would be "peculiarly inappropriate in areas as complex as water pollution control."218 The Court stated that any judicial approach applying federal common law inevitably would be "sporadic" " and " 'ad hoc," " a result inconsistent with Congress's intent in enacting the 1972 amendments. ${ }^{220}$

The Court's opinion, by Justice Rehnquist, rejected Illinois' contention that the statute itself preserved the state's right to invoke the federal common law of nuisance to abate Milwaukee's discharges. In particular, Illinois relied on the "savings clause" of the citizen suit provisions of the Act, which states that "[n]othing in this section shall restrict any right which any person may have under any statute or com-

213 Id. at 315 (quoting Mobil Oil Corp. v. Higginbotham, 436 U.S. 618, 625 (1978)); see also id. at 324 ("The question is whether the field has been occupied, not whether it has been occupied in a particular manner.") (footnote omitted).

214 The amendments were enacted several months after the Court's decision in Milwaukee I. See supra text accompanying notes 205-06.

216 Milwaukee II, 451 U.S. at 317.

$218 \mathrm{Id}$. at 320.

217 See id.

218 Id. at 323.

219 Id. at 325. According to the majority, resolution of the technical problems involved in this area would be "particularly unsuited to the approach inevitable under a regime of federal common law." Id. The Court suggested that it would be inconsistent with the statute's delegation of authority to an expert administrative agency, the EPA, "if federal courts were in effect to 'write their own ticket" "by imposing requirements on a point source discharger under the federal common law that were more stringent than those included in the permit issued to the discharger pursuant to the Clean Water Act. Id. at 326. But see Weinberger v. Romero-Barcelo, 456 U.S. 305 (1982), in which, precisely one year after its decision in Milwaukee II, the Court concluded that the statutory scheme embodied in the Clean Water Act "contemplates the exercise of discretion and balancing of equities" by federal district courts in private citizen suits to enforce the statute. Romero-Barcelo, 456 U.S. at 316.

220 See Milwaukee II, 451 U.S. at 325 (quoting S. REP. No. 414, 92d Cong., 1st Sess. 95 (1971)). But see Weinberger v. Romero-Barcelo, 456 U.S. 305, 320 (1982) (The Clean Water Act "permits the District Court to order that relief it considers necessary to secure prompt compliance with the Act. That relief can include, but is not limited to, an order of immediate cessation."). 
mon law."221 The Court responded first that it was "unlikely" that Congress intended the reference to common law in the "savings clause" to include "the limited federal common law as opposed to the more routine state common law."222 Second, even assuming that Congress intended to refer to federal as well as state common law, the Court construed the savings clause to mean only that nothing "in this section"-that is, the citizen suit provisions of the statute ${ }^{223}$ - preempted the federal common law of nuisance. The majority opinion concluded, however, that the rest of the statute was intended to have such a preemptive effect. ${ }^{224}$

Similarly, the Court rejected the claim that section 510 of the statute expressly preserved Illinois' federal common-law action. Section 510 authorizes states to adopt or enforce standards for the control of pollutants, provided that those standards are no less stringent than the standards prescribed under the Glean Water Act. ${ }^{225}$ Citing no support for its analysis in the legislative history or elsewhere, the Court found that although this provision permitted the states to apply their own, more stringent state standards to in-state dischargers, Congress did not intend to allow states to employ federal common law to apply these

22133 U.S.C. § 1365(e). The "savings clause" applies to the "right . . . to seek enforcement of any effluent standard or limitation or to seek any other relief (including relief against the Administrator or a State agency)." Id.

${ }^{222}$ Milwaukee II, 451 U.S. at 329. Although the Court attempted to support this conclusory assertion by references to the legislative history, Justice Rehnquist, writing for the majority, acknowledged that nothing in the portions of the legislative history to which he referred "suggests any intent concerning the continued validity of federal common law." Id. at 332 (emphasis added). Justice Blackmun's dissent contends, on the other hand, that the legislative history indicates "that Congress was specifically aware of the presence of federal common law, and intended that it would survive passage of the 1972 Amendments." Id. at 343 (Blackmun, J., dissenting).

22333 U.S.C. \& 1365.

224 Milwaukee II, 451 U.S. at 328-29.

225 Section 510 of the Act provides in part as follows:

Except as expressly provided in this . . . [Act], nothing in this . . . [Act] shall (1) preclude or deny the right of any State or political subdivision thereof . . . to adopt or enforce (A) any standard or limitation respecting discharges of pollutants, or (B) any requirement respecting control or abatement of pollution; except that if an effluent limitation or other limitation, effluent standard, prohibition, pretreatment standard, or standard of performance is in effect under this . . . [Act], such State or political subdivision . . . may not adopt or enforce any effluent limitation, or other limitation, effluent standard, prohibition, pretreatment standard, or standard of performance which is less stringent than the effluent limitation, or other limitation, effluent standard, prohibition, pretreatment standard, or standard of performance under this . . . [Act]; or (2) be construed as impairing or in any manner affecting any right or jurisdiction of the States with respect to the waters (including boundary waters) of such States.

33 U.S.C. $\S 1370$. 
more stringent standards to out-of-state dischargers. ${ }^{226}$

In a strongly worded dissent, ${ }^{227}$ Justice Blackmun characterized the majority's reading of the statute as "extremely strained" and "at odds with the manifest intent of Congress to permit more stringent remedies under both federal and state law."228 In response to the majority's assertion that it was unlikely that Congress intended the savings clauses of the citizen suit provision to encompass federal common law, Justice Blackmun pointed out that the clause "makes no distinction between the common law of individual States and the federal common law."229 The dissenting opinion labeled the Court's conclusion-that although the savings clause did not preempt federal common law, the rest of the Clean Water Act did-an unjustified "license to supplant all legal remedies outside the Act itself."230

The interpretation of the statute reflected in the dissenting opinion is more convincing than that in Justice Rehnquist's opinion. If Congress intended the enactment of the 1972 amendments as a whole to preempt federal common law, it is difficult to understand why it did not make an affirmative statement to that effect. It is hard to imagine a more cryptic way of expressing an intent to preempt federal common law than to expect the intent to be derived by negative implication from a statement that nothing in the very section creating a new statutory private remedy has preemptive effect. The savings clause of the citizen suit provision, moreover, draws no distinction between federal and state common law. ${ }^{231}$ Justice Rehnquist failed to unearth anything in the legislative history to demonstrate that Congress intended to limit supplemental common-law remedies to those derived from state law. The majority's suggestion that section 510 , although not expressly so limited, only authorizes the states to enforce more stringent standards against in-state dischargers under state law is also based on unsupported speculation. ${ }^{232}$

Moving beyond narrow issues of statutory interpretation, one must also question the Court's decision in Milwaukee II in terms of the extent to which it promotes the implicit statutory and constitutional val-

226 See Milwaukee II, 451 U.S. at 328.

227 Justice Blackmun was joined in his dissenting opinion by Justices Marshall and Stevens. See id. at 332-54.

${ }_{228}$ Id. at 342 (Blackmun, J., dissenting).

229 Id. at 343.

230 Id. at 342.

231 See supra text accompanying notes 221 \& 229.

232 See Farber, supra note 92, at 520 ("[N]othing in the statute indicates an intention to preempt the federal common law. The Court's holding therefore seems to have been based on the desire to avoid an independent policymaking role for the courts in an area where Congress had acted."). 
ues of legitimacy, individual liberty, accommodation, and efficiency. The majority's opinion appears to reflect the conviction that the preemption of federal common law is supported by the first three of these values. ${ }^{233}$ It is not difficult to argue, however, that the Court's decision is, in fact, inconsistent with each of these three values.

The Court's opinion reflects the belief that its holding will promote the legitimacy of the federal effort to control water pollution by fostering greater political accountability, more informed decisionmaking, and increased certainty concerning the obligations of dischargers subject to the Clean Water Act. According to Justice Rehnquist, rules of conduct, such as limitations on water pollutant discharges, should generally be formulated by "the people through their elected representatives in Congress," rather than "by the federal judiciary, purposefully insulated from democratic pressures."234 Congress, on the other hand, frequently leaves gaps in the legislation it enacts. "[P]articipation by the federal courts," Justice Blackmun asserted in dissent, "is often desirable, and indeed necessary, if federal policies developed by Congress are to be fully effectuated."2ss Furthermore, if the Court's interpretation of those provisions of the Clean Water Act that apparently preserve all common-law remedies is indeed a distortion of congressional intent, ${ }^{236}$ then the holding in Milwaukee II represents the judiciary's refusal to implement duly enacted legislation, thereby frustrating political accountability. As Justice Blackmun pointed out, the Supreme Court "is no more free to disregard expressions of legislative desire to preserve federal common law than it is to overlook congressional intent to curtail it."2sz

The majority's contention that its decision will promote informed decisionmaking, fairness, and certainty are only slightly more convinc-

29s Although Justice Rehnquist did not make the argument expressly, the preemption of federal common-law actions may improve the efficiency of the Clean Water Act's implementation. Under this view, it would be a waste of resources to permit a person who fails to convince the EPA that a discharger's effluence must be limited to a certain level to make those same arguments a second time in federal court. See W. RODGERS, supra note 74, at 42; see also R. STEWART \& J. KRIER, supra note 78, at 199 ("[J] udicial efforts to dictate an efficient outcome in each case threaten[ ] very high transactions costs . . . ."). But see Milwaukee II, 451 U.S. at 345 (Blackmun, J., dissenting) ("Congress never intended that failure to participate in the $\S 402$ administrative process would serve as a jurisdictional bar."). On the other hand, the preservation of federal common-law remedies may promote economic efficiency by forcing polluters to internalize their costs. See infra notes 395-96 and accompanying text.

234 Milwaukee II, 451 U.S. at 313.

${ }^{235} I d$. at 334 n.2 (Blackmun, J., dissenting).

236 See supra notes 231-32 and accompanying text.

${ }^{237} 451$ U.S. at 339 n.8 (Blackmun, J., dissenting) (citing Isbrandtsen Co. v. Johnson, 343 U.S. 779, 783 (1952), for the proposition that unless congressional intent is clear, statutes should not be construed in derogation of the common law). 
ing. Justice Rehnquist's opinion deems the use of federal common law "peculiarly inappropriate in areas as complex as water pollution control," in part because of the "arcane subject matter" and technical problems involved. ${ }^{238}$ But the Court expressed no such doubts about judicial competence exactly one year later when, in the Romero-Barcelo decision, it attributed to Congress an intent to vest broad discretion in the federal district courts to fashion relief that they consider necessary to secure prompt compliance with the Clean Water Act. ${ }^{239}$ The majority accurately characterized a system of pollution control based on federal common-law actions as "sporadic" " and "ad hoc." "240 It also correctly noted that certainty suffers if a discharger who complies with a Glean Water Act permit issued by the EPA or a state can be forced subsequently to comply with more stringent, judicially imposed effluent limitations. ${ }^{241}$ If Congress decides that the value of certainty should yield to the courts' ability to advance the important federal interest in water pollution control on a case-by-case basis, however, the courts are not free to subvert that decision. ${ }^{242}$

Justice Rehnquist's opinion asserts that, once Congress has addressed a problem, the Court's " 'commitment to the separation of powers is too fundamental' to continue to rely on federal common law 'by judicially decreeing what accords with common sense and the public weal." "243 According to Justice Rehnquist, the district court in Milwaukee II was not free to resort to federal common law as the basis for applying more stringent effluent limitations on the city merely because the court disagreed with the regulatory approach taken by the agency charged by Congress with the responsibility to issue permits. ${ }^{244}$ The statute, however, expressly authorizes the federal courts to continue resolving interstate pollution disputes by reference to common-law

238 Id. at 325.

239 See Romero-Barcelo, 456 U.S. at 316, 320. Justice Rehnquist, the author of the majority opinion in Milwaukee II, joined Justice White's majority opinion in Romero-Barcelo. Furthermore, state courts have dealt with similar scientific and technical issues for years in common-law nuisance actions. It is difficult to see why federal judges are less capable of understanding such issues than their state court counterparts. See Milwaukee II, 451 U.S. at 349 \& n.25 (Blackmun, J., dissenting).

${ }^{240}$ Milwaukee II, 451 U.S. at 325 (quoting S. REP. No. 414, 92d Cong., 1st Sess. 95 (1971)).

211 See id. at 326.

242 See id. at 339 n. 8 (Blackmun, J., dissenting).

243 Id. at 315 (quoting Tennessee Valley Auth. v. Hill, 437 U.S. 153, 195 (1978)). The Court also noted that its ruling was compelled by "the usual and important concerns of an appropriate division of functions between the Congress and the federal judiciary." Id. at 313.

244 See id. at 323. 
principles. ${ }^{245}$ The Court's refusal to do so constitutes an infringement on legislative authority that is inconsistent with separation of powers principles. ${ }^{246}$

The Court also indicated that its decision would protect the integrity of state sovereignty. Justice Rehnquist contended that since the states are represented in Congress, the states are more capable of protecting their interests when Congress is the source of federal law than when federal courts develop common law to respond to a dispute. ${ }^{247}$ In addition, Rehnquist asserted that the Clean Water Act provides "ample opportunity for a State affected by decisions of a neighboring State's permit-granting agency to seek redress" through participation in the permit-issuing process. ${ }^{248}$

It is not clear, however, that the Clean Water Act provides adequate means for a state to protect its resources from impairment by another state or its citizens. ${ }^{249}$ Suppose, for example, that Milwaukee is complying with all federally issued effluent limitations as well as any additional limitations issued by Wisconsin. The Clean Water Act may provide no basis for Illinois to seek an abatement of Milwaukee's discharges through the application of Illinois' more stringent effluent limitations, even if those discharges are causing harm to Illinois residents or

245 See supra notes $225-30$ and accompanying text.

246 See 451 U.S. at 338-41 (Blackmun, J., dissenting).

247 See id. at 317 n.9.

248 Id. at 325-26; see also 33 U.S.C. $\$ 1342$ (b)(3) (requiring state permit programs to ensure that a state whose waters may be affected by the issuance of a permit receives notice of each permit application and an opportunity to participate in a public hearing).

249 The Court's conclusion that the 1972 legislation deals "comprehensively" with the problem of water pollution control, see 451 U.S. at 317 , is subject to debate. Compare Fort, supra note 160, at 146-56 (describing "the comprehensive scheme Congress created to regulate" air and water pollution and hazardous waste disposal) with Comment, supra note 90, at 334 (describing "the inability of the EPA to implement the [Clean Water Act] so as to be truly comprehensive"); id. at 363-64 (focusing on a state's inability to enforce its own, more stringent pollution control standards against assault from extraterritorial sources) and Note, Non-Statutory Pollution Remedies in the Wake of City of Milwaukee v. Illinois, 35 RUTGers L. REv. 595, 603-08 (1983) (contending that the 1972 legislation does not effectively address "the central issue" in Milwaukee II, since the statute "provides no definite enforcement mechanism to assure that [an emitting] state's discharges do not cause a violation" of the receiving state's standards where the latter are more stringent than the minimum federal standards promulgated under the federal act). See also Note, supra note 192, at 530-31 (The Clean Water Act, after the 1977 amendments, like the Federal Water Pollution Control Act after the 1972 amendments, "fails to provide a means of protecting a state's quasi-sovereign interests in interstate water from pollution permitted in a neighboring state."). But see 33 U.S.C. § 1341(a)(2) (Federal agencies, including the EPA, issuing permits for discharges into navigable waters must "condition such ... permit[s] in such manner as may be necessary to insure compliance with applicable water quality requirements. If the imposition of conditions cannot insure such compliance such agency shall not issue such . . . permit[s]."). 
resources. ${ }^{250}$ The preemption of federal common-law remedies may leave Illinois unable to protect its "right to be free from unreasonable interference with its natural environment and resources when the interference stems from another State or its citizens."251 This significant infringement on Illinois' sovereignty is inconsistent with the pursuit of individual liberty, a substantive value more important than procedural values such as legitimacy and accommodation. ${ }^{\mathbf{2 8 2}}$

Finally, as the Court pointed out in Milwaukee $I$, a state's resort to federal common-law remedies against an out-of-state polluter may very well promote the accommodation of conflicting state interests by providing a federal rule and forum to resolve the dispute. ${ }^{253}$ Federal common law can also resolve potential conflicts between federal and state interests by protecting the federal interests in a minimum level of environmental quality and the preservation of important national resources. $^{254}$

\section{The Implications of Milwaukee II}

Whether federal common law in the areas of air pollution and hazardous waste disposal survives after Milwaukee II is uncertain. ${ }^{255}$

${ }^{250}$ See Milwaukee II, 451 U.S. at 353 n.32 (Blackmun, J., dissenting) ("[I]f a polluting State is not violating its own approved standards, a neighboring State with higher standards then has no recourse under [the Clean Water Act]. It is in precisely this context that the Court recognized the significance of federal common law.") (citing Milwaukee 1, 406 U.S. at 107-08); see also infra text accompanying notes 445-48 (noting that the Act may fail to protect an injured state having more stringent standards from a source outside the state that meets the minimum federal requirements). But see 33 U.S.C. § 1341(a)(2) (providing that "[w]henever such a discharge may affect . . . the quality of the waters of any other State," and "the other State determines that such discharge will affect the quality of its waters so as to violate any water quality requirements in such State," the EPA shall hold a hearing and condition the issuance of a permit on "compliance with applicable water quality requirements").

${ }^{251}$ Milwaukee II, 451 U.S. at 335 (Blackmun, J., dissenting) (citing Georgia v. Tennessee Copper Co., 206 U.S. 230, 237-39 (1907); Missouri v. Illinois, 200 U.S. 496, 520, 526 (1906)).

${ }^{252}$ See supra notes $71,149-54$ and accompanying text. This infringement on Illinois' sovereignty would be avoided if Illinois could apply its own, more stringent standards against Milwaukee in a state common-law action. See infra text accompanying notes 436-56.

${ }^{203}$ See supra text accompanying notes 190-92.

254 See supra text accompanying notes 193-98.

${ }^{255}$ Any doubts about the scope of the Court's decision in Milwaukee II in the area of water pollution were dispelled several months after Milwaukee II was decided. The Court held in National Sea Clammers that "the federal common law of nuisance in the area of water pollution is entirely pre-empted by the more comprehensive scope of the [Federal Water Pollution Control Act], which was completely revised soon after the decision in [Milwaukee I]." 453 U.S. at 22 (citing Milwaukee II). Federal common law in the area of ocean pollution was also preempted, by the enactment of the Marine Protection, Research, and Sanctuaries Act, 33 U.S.C. \$§ 1401-1445 (1982). See Na- 
The analysis in Milwaukee II indicates that courts will start with the assumption that federal law emanates from Congress, not the federal courts. ${ }^{256}$ If Congress, in adopting a statutory scheme, has "spoken directly to" a question, the courts will not be willing to apply federal common law absent a clear congressional intent to preserve federal common-law remedies. ${ }^{267}$ The Clean Water Act prohibits every point source discharge into navigable waters unless covered by a permit issued by the EPA or a state with an approved permit program. ${ }^{258}$ The Court in Milwaukee II relied on this broad prohibition to characterize the Act as "an all-encompassing program of water pollution regulation,"258 which left no room for supplemental federal common-law rules. $^{280}$

Several subsequent lower court decisions have employed a similar rationale to conclude that federal pollution control legislation has "occupied the fields" of maritime tort law $^{261}$ and air pollution control. ${ }^{262}$

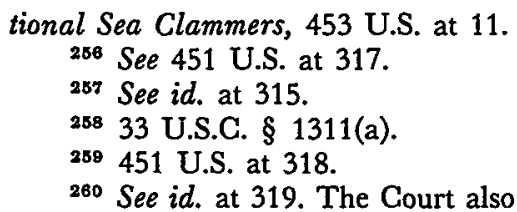

has been thoroughly addressed through the that "the problem of effuent limitations hs been thoroughly addressed through the administrative scheme established by Congress." Id. at 320. But see Stafford, The Supreme Court, Federal Common Law, and Congressional Efforts to Protect Health and the Environment, 14 ENvTL. L. REP. $10,103,10,104$ (1984) ("The supposition that the Clean Water Act is, in fact, a comprehensive scheme of regulation is troubling.").

${ }^{261}$ See, e.g., Conner v. Aerovox, Inc., 730 F.2d 835, 842 (1st Cir. 1984); In re Oswego Barge Corp., 664 F.2d 327, 335-39 (2d Cir. 1981). One court has extended the holdings in Milwaukee II and National Sea Clammers to federal common-law remedies for nuisances resulting from discharges of pollutants into navigable waters that occurred before the adoption of the 1972 amendments to the Clean Water Act. See Illinois v. Outboard Marine Corp., 680 F.2d 473, 478 (7th Cir. 1982).

${ }^{282}$ See, e.g., Reeger v. Mill Serv., Inc., 593 F. Supp. 360,363 (W.D. Pa. 1984) ("We find the regulatory scheme under the federal Clean Air Act to be similar to that of the acts considered in [National] Sea Clammers, and therefore apply the same principles of preemption."); United States v. Kin-Buc, Inc., 532 F. Supp. 699, 701-02 (D.N.J. 1982) (holding that, even though the Clean Air Act, unlike the Clean Water Act, does not regulate all stationary emission sources of pollutants, the Clean Air Act preempts the federal common law of nuisance because "Congress has addressed the problem of air pollution" through the establishment of a comprehensive regulatory program); see also New England Legal Found. v. Costle, 666 F.2d 30, 32 (2d Cir. 1981) (The EPA's approval of a variance from New York's state implementation plan, permitting a company to burn high sulfur fuel, precludes a court from finding that such burning constitutes a federal common-law nuisance.). But cf. id. at 32 (refusing to address "the broad question of whether the Clean Air Act totally preempts federal common law nuisance actions based on the emission of chemical pollutants into the air"). The Costle court, like the court in Kin-Buc, noted that the Clean Air Act does not require the EPA or the states to control emissions from every stationary source, but only from those sources threatening the national ambient air quality standards. See $i d$. at 32 n.2. 
Several courts have also held that, based on the comprehensive nature of the statutory programs established by RCRA and CERCLA, Congress has occupied the field of hazardous waste disposal, thereby preempting federal common law. ${ }^{263}$

Justice Blackmun, in his dissent in Milwaukee $I I$, feared that an "automatic displacement" approach would result from the majority's conclusion that federal common law is preempted as soon as Congress "addresses a question previously governed" by that law. ${ }^{264}$ These fears have been justified in at least one case, in which a federal district court held that the enactment of the Clean Water Act preempted federal common-law rules for non-point sources of pollution. ${ }^{265}$ The Glean Water Act's National Pollutant Discharge Elimination System (NPDES) permit program, on which the Court relied in Milwaukee $I I,{ }^{268}$ applies only to discharges of pollutants from point sources into navigable waters. ${ }^{267}$ The Act's coverage of non-point sources of pollution, such as agricultural field or construction site runoff, is far less extensive. ${ }^{268}$ Because Congress has failed to authorize, and because the EPA has not implemented, a truly comprehensive program of non-point source control, a finding that federal common-law remedies have been preempted is harder to justify with non-point sources than it is in the point source context.

If the courts are willing to look more closely at the scope of particular statutory programs, they may conclude that discrete areas of federal common law have survived despite the enactment of related pollution control statutes. For example, there is evidence that acid rain deposition is at least in part a long-range phenomenon in which emissions of sulfur dioxide or oxides of nitrogen in one state result in acidic deposition in another state. ${ }^{269}$ The Clean Air Act's principal mecha-

${ }^{263}$ See, e.g., Philadelphia v. Stepan Chem. Co., 544 F. Supp. 1135, 1147-48 (E.D. Pa. 1982); United States v. Price, 523 F. Supp. 1055, 1069 (D.N.J. 1981), affd, 688 F.2d 205 (3d Cir. 1982); see also Hinds, Liability Under Federal Law for Hazardous Waste Injuries, 6 HARv. ENvTL. L. REv. 1, 10-12 (1982) (contending that the comprehensive character of RCRA and CERCLA dictates the conclusion that the federal common law of nuisance for hazardous wastes has been preempted).

${ }^{264}$ See Milwaukee II, 451 U.S. at 334 (Blackmun, J., dissenting).

${ }^{285}$ See United States v. Olin, 11 EnvTl. L. REP. 21,026, 21,026 (N.D. Ala. 1981). Non-point sources of pollution do not emit pollutants from a discrete pipe, channel, or conduit. Cf. 33 U.S.C. § 1362(14) (defining point source). Non-point sources include agricultural fields, mining activities, and construction sites. See id. $\S 1314(\mathrm{f})$.

${ }^{208}$ See supra text accompanying note 248.

${ }_{287}$ See 33 U.S.C. $\S \S 1311(a), 1342(a)(1)$.

${ }^{268}$ See F. ANDERSON, D. MANDELKer \& A. TARLOCK, supra note 60, at 356-64; J. BonINE \& T. MCGARITY, supra note 89, at 436-38; T. SchoenBaUM, supra note 72 , at $740-42$.

269 See Note, supra note 198 , at 145-50. 
nism for controlling interstate pollution is contained in section 126 of the Act, which authorizes a state to petition the EPA for a finding that the emissions of a major stationary source in another state are interfering with the receiving state's efforts to attain or maintain the national ambient air quality standards. ${ }^{270}$ The EPA has concluded, however, that the section 126 petition procedures apply only to pollutants for which the EPA has established national ambient air quality standards. ${ }^{271}$ These standards have been promulgated for sulfur dioxide and oxides of nitrogen, but not for acid deposition, which is caused when these two pollutants combine with materials in the atmosphere to form sulfuric or nitric acid. Since the Clean Air Act's special provisions for controlling interstate pollution do not apply to acid deposition, Congress arguably has not "spoken directly"272 to the problem of acid rain transport and deposition. Thus, even if federal common law has been preempted in the general area of air pollution, ${ }^{273}$ federal common-law remedies still should be available to abate acid deposition. ${ }^{274}$

Similarly, the federal courts should be able to formulate federal common-law rules, despite the creation of a statutory pollution control program, if Congress authorizes the courts to fill gaps in or supplement the statutory program. Some courts, for example, have concluded that Congress intended the federal courts to develop federal common-law principles in construing and applying certain provisions of CERGLA. ${ }^{275}$ These courts have resorted to a new body of judicially developed principles ${ }^{276}$ to determine who is responsible for reimbursing the government for costs incurred in responding to releases of hazardous substances from abandoned or inactive waste disposal facilities. ${ }^{277}$

${ }^{270}$ See 42 U.S.C. $\$ \S 7410(a)(2)(E), 7426$ (1982). The national ambient air quality standards, promulgated by the EPA for pollutants such as sulfur dioxide, oxides of nitrogen, and particulate matter, must be achieved by the states within time periods set forth in the Act. See id. $\$ \S 7409,7410(\mathrm{a})(2)(\mathrm{A})$.

${ }^{271}$ See 49 Fed. Reg. 48,152 (1984) (final determination concerning interstate pollution abatement).

${ }^{272}$ Milwaukee II, 451 U.S. at 315.

${ }^{273}$ See supra note 262.

274 See Bleiweiss, Environmental Regulation and the Federal Common Law of Nuisance: A Proposed Standard of Preemption, 7 HARv. EnvTL. L. Rev. 41, 67-68 (1983); Comment, supra note 90, at 402-05; Note, supra note 198, at 165-78.

${ }_{278}$ See, e.g., United States v. Chem-Dyne Corp., 572 F. Supp. 802, 808 (S.D. Ohio 1983) ("[T]he inevitable incompleteness presented by all legislation means that interstitial federal lawmaking is a basic responsibility of the federal courts.").

278 This body of law, which fills gaps left by Congress when it enacted CERCLA, has been referred to as "statutory common law." See J. BonINE \& T. McGarity, supra note 89, at 1008, 1025, 1038.

${ }^{277}$ See, e.g., United States v. Conservation Chem. Co., 589 F. Supp. 59, 62-63 (W.D. Mo. 1984); United States v. Northeastern Pharmaceutical \& Chem. Co., 579 F. Supp. 823, 839-46 (W.D. Mo. 1984); United States v. A \& F Materials Co., 578 F. 
Thus, although the use of federal common law in suits involving harm caused by pollution has been narrowly confined by the decision in Milwaukee II, there remain areas in which the courts should not hesitate to resort to federal common law.

\section{State Gommon-Law Remedies}

The federal statutes controlling the discharge of air and water pollutants and the disposal of hazardous wastes contain citizen suit provisions authorizing private persons to bring suits to enjoin statutory violations. These citizen suit provisions, however, do not create any, right of compensation for individuals harmed by pollutant discharges regulated under the statutes. The courts, guided by the Supreme Court's analysis in Middlesex County Sewerage Authority v. National Sea Clammers, ${ }^{278}$ have been unwilling to imply such a private right of action. ${ }^{278}$

Supp. 1249, 1252-55 (S.D. Ill. 1984); United States v. Stringfellow, 20 Env't Rep. Cas. (BNA) 1905, 1911-12 (C.D. Cal. 1984); United States v. South Carolina Recycling \& Disposal, Inc., 20 Env't Rep. Cas. (BNA) 1753, 1756-60 (D.S.C. 1984); United States v. Wade, 577 F. Supp. 1326, 1337-39 (E.D. Pa. 1983); United States v. Chem-Dyne Corp., 572 F. Supp. 802, 806-08 (S.D. Ohio 1983).

Some courts have also concluded that the provisions of RCRA and CERCLA authorizing the federal district courts to abate situations causing an imminent and substantial endangerment to public health or welfare, 42 U.S.C.A. $\S 6973$ (West 1983 \& Supp. 1985); 42 U.S.C. $\$ 9606$, are a codification of federal common law. In United States v. Waste Indus., Inc., 734 F.2d 159 (4th Cir. 1984), for example, the court discussed the imminent hazard provision of RCRA in the following terms:

Congress's intent, then, was to establish a standard of liability by incorporating and expanding upon the common law. ... [T] [he former common law of nuisance, as applied to situations in which a risk of harm from solid or hazardous wastes exists, shall include new terms and concepts which shall be developed in a liberal, not a restrictive, manner.

Id. at 167; see also Jones v. Inmont Corp., 584 F. Supp. 1425, 1433-35 (S.D. Ohio 1984); S. REP. No. 172, 96th Cong., 2d Sess. 5 (1980), reprinted in 1980 U.S. CoDE ConG. \& AD. NEws 5019, 5023. The Senate Report on RCRA states:

Section 7003 [current version at 42 U.S.C.A. $§ 6973$ (West 1983 \& Supp. 1985)], therefore, incorporates the legal theories used for centuries to assess liability for creating a public nuisance (including intentional tort, negligenc[e] and strict liability) and to determine appropriate remedies in common law history attached to terms such as "imminent" and "substantial," as well as more recent legislative history. However, section 7003 should not be construed solely with respect to the common law. Some terms and concepts, such as persons 'contributing to' disposal resulting in a substantial endangerment, are meant to be more liberal than their common law counterparts.

Id. Not all courts agree that the imminent hazard provisions of RCRA and GERCLA have a substantive content that reflects a codification of common-law principles. See, e.g., United States v. Solvents Recovery Serv., 496 F. Supp. 1127, 1133-34 (D. Conn. 1980); United States v. Midwest Solvent Recovery, Inc., 484 F. Supp. 138, 143-44 (N.D. Ind. 1980).

278454 U.S. 1 (1981).

279 See supra note 90 and accompanying text. 
Even assuming that the federal common law of nuisance encompasses a private plaintiff's effort to seek monetary relief, ${ }^{280}$ the Court's decision in Illinois v. City of Milwaukee (Milwaukee II) ${ }^{281}$ has foreclosed that avenue in the water pollution context, and probably in many air pollution and hazardous waste disposal controversies as well, ${ }^{282}$ on the ground that the enactment of comprehensive legislative schemes for pollution control has preempted federal common-law actions. ${ }^{283}$ Apparently, individuals seeking compensation for harm to their health or property caused by pollution are limited to whatever remedies have been provided by state law.

This section addresses whether state common-law compensatory or injunctive remedies have been preempted by the enactment of the Clean Air and Water Acts, RCRA, and CERCLA. ${ }^{284}$ The analysis indicates that although Congress has the authority under the commerce clause ${ }^{285}$ to preempt state common-law remedies for harm caused by pollution, it has not intended to do so in most instances.

This part of the Article is divided into six sections. The first two sections analyze Congress's authority to preempt state common-law remedies and the general principles applied by the courts in preemption cases. The third section considers whether the Clean Air and Water Acts have preempted the application of state common-law remedies when the person injured and the polluter causing the injury are located in the same state. The fourth section considers the preemption question in the context of a polluter located in one state who causes harm to a person located in another state. The fifth section contains a separate analysis of the preemptive effect of RCRA and GERCLA. The final section proposes that Congress either reauthorize the use of federal common law to resolve interstate pollution controversies or create a federal statutory private right of action for damages resulting from interstate pollution. The legislature could then expressly preclude the application of state common-law remedies to interstate disputes, and thus avoid the potential difficulties created by the application of different

280 The divergent views of the federal courts on the scope of the federal common law of nuisance are discussed supra note 198.

281451 U.S. 304 (1981).

${ }^{282}$ But see supra notes $269-77$ and accompanying text.

${ }^{283}$ See supra notes $255-65$ and accompanying text.

284 The analysis of congressional authority and intent to preempt state statutory remedies does not differ significantly from this section's analysis of state common-law remedies. For example, the savings clause of the Clean Water Act's citizen suit provision denies any intent to restrict any person's right to seek relief "under any statute or common law." 33 U.S.C. § 1365(e).

${ }^{28 s}$ U.S. CoNST. art. I, $\S 8, \mathrm{cl} .3$. 
standards of liability to polluters.

\section{A. Congressional Preemption Authority}

\section{Commerce Clause Authority}

In determining whether Congress has preempted a certain body of state law, it is necessary to engage in a two-step analysis. The first question is whether Congress has the constitutional power to preempt state law. Assuming that Congress is authorized to act, the second inquiry is whether it intended to displace state law when it enacted a particular statute. ${ }^{286}$ If Congress is authorized to preempt state law and intended to do so, the states are precluded from exercising legislative or judicial power in the preempted field. ${ }^{\mathbf{2 8 z}}$

The scope of Congress's authority to displace state common-law remedies for pollution-induced harm is related to its authority to regulate various sources of pollutants. ${ }^{288}$ Although the Supreme Court has never held that the Clean Air Act, the Glean Water Act, RCRA, or GERCLA are within Congress's constitutional authority, ${ }^{289}$ there is little doubt that these statutes are within the ambit of Congress's commerce clause powers. ${ }^{290}$

${ }^{288}$ See Pacific Gas \& Elec. Co. v. State Energy Resources Conservation \& Dev. Comm'n, 461 U.S. 190, 203 (1983) ("It is well established that within constitutional limits Congress may pre-empt state authority by so stating in express terms."); see also L. TRIBE, AMERICAN ConstituTional LAw § 6-23, at 376 (1978) ("So long as Congress acts within an area delegated to it, the preemption of conflicting state or local action ... flow[s] directly from the substantive source of the congressional action coupled with the supremacy clause .....").

${ }^{287}$ The displacement of state law is based on the supremacy clause of the Constitution, which provides in part that the "Constitution, and the Laws of the United States which shall be made in Pursuance thereof . . . shall be the supreme Law of the Land; and the Judges in every State shall be bound thereby, any Thing in the Constitution or Laws of any State to the Contrary notwithstanding." U.S. CoNST. art. VI; see also Note, Environmental Control: Higher State Standards and the Question of Preemption, 55 CORNELl L. REv. 846, 851 (1970) (The effect of the supremacy clause "is to give Congress the power to impede the state's exercise of concurrent power by means of legislation, otherwise constitutional, that displaces state laws."). See generally Pierce, supra note 66 (discussing agency power to preempt state regulation).

${ }^{288}$ An award of compensatory damages can be viewed as a form of regulation of the defendant polluter. "[R]egulation can be as effectively exerted through an award of damages as through some form of preventive relief." San Diego Bldg. Trades Council v. Garmon, 359 U.S. 236, 247 (1959).

${ }^{280}$ See McCastle v. Rollins Envtl. Serv., 514 F. Supp. 936, 941 (M.D. La. 1981) (declining to consider "whether the Constitution grants to the Congress the authority to supercede state law in actions between private parties relating to discharges of substances into the ambient air in each and every part of the country"); Stewart, Pyramids of Sacrifice, supra note 67, at 1225 .

${ }^{280}$ The commerce clause gives Congress the power "[t]o regulate Commerce with foreign Nations, and among the several States, and with the Indian tribes." U.S. 
In 1981 the Supreme Court addressed a similar issue in Hodel v. Virginia Surface Mining $\mathcal{E}^{\circ}$ Reclamation Association. ${ }^{291}$ In Hodel an association of local coal producers brought suit challenging the constitutionality of the Surface Mining Control and Reclamation Act of 1977,282 "a comprehensive statute designed to 'establish a nationwide program to protect society and the environment from the adverse effects of surface coal mining operations.' "293 The Act authorizes the Secretary of the Interior to issue performance standards requiring coal producers to restore land to its prior condition after mining, segregate and preserve topsoil, minimize disturbances to the hydrologic balance, and revegetate mined areas. ${ }^{204}$ The coal producers' association asserted that the Act exceeded Congress's authority under the commerce clause ${ }^{295}$ because its principal goal was regulating the use of private lands within the borders of the states, as opposed to regulating the effects of surface coal mining on interstate commerce. ${ }^{298}$

The Court upheld the statute against this challenge. The Court's review was "influenced above all by the fact that the Commerce Clause is a grant of plenary authority to Congress." ${ }^{\text {287 }}$ The Court concluded that the fact that an activity is labeled "local" or "intrastate" does not necessarily preclude Congress from regulating it under its commerce clause authority. ${ }^{288}$ Congress set forth numerous findings, in both the statute and its legislative history, detailing the effects of surface coal mining on interstate commerce. Because the Court could not say that these findings lacked a rational basis, it rejected the coal producers' commerce clause argument. ${ }^{299}$

Congress has enunciated similar findings concerning the effects of air and water pollution and hazardous waste disposal on interstate

\section{Const. art. I, $\S 8, \mathrm{cl} .3$.}

281452 U.S. 264 (1981); see also Hodel v. Indiana, 452 U.S. 314 (1981) (upholding the constitutionality of the "prime farmland" provisions of the 1977 Surface Mining Control and Reclamation Act, 30 U.S.C. $\$ \S 1201-1328$ (1982)).

20230 U.S.C. $\S \S 1201-1328$ (1982).

${ }^{203}$ Virginia Surface Mining, 452 U.S. at 268 (quoting 30 U.S.C. § 1202(a)).

294 See id. at 269 (citing 30 U.S.C. § 1265(b)).

295 U.S. CoNST. art. I, \& 8, cl. 3. The association also argued that the Act violated the tenth amendment and the due process, equal protection, and just compensation guarantees of the fifth amendment. See Virginia Surface Mining, 452 U.S. at 273. The Court's treatment of the tenth amendment issues is considered infra note 318 and accompanying text.

${ }^{298}$ See Virginia Surface Mining, 452 U.S. at 275.

297 Id. at 276; see also Hodel v. Indiana, 452 U.S. 314, 324 (1981) (" "The power of Congress to regulate interstate commerce is plenary and extends to all such commerce be it great or small." ") (quoting NLRB v. Fainblatt, 306 U.S. 601, 606 (1939)).

${ }^{208}$ See Virginia Surface Mining, 452 U.S. at 281.

290 See id. at 277-83. 
commerce. ${ }^{300}$ In a series of lower court decisions, the courts have concluded that the congressional findings provide ample basis for upholding the federal pollution control statutes as appropriate exercises of the commerce clause power. ${ }^{301}$ In strongly worded dictum, the Supreme Court in Hodel "agree[d] with [those] courts that have uniformly found the power conferred by the Commerce Glause broad enough to permit congressional regulation of activities causing air or water pollution, or other environmental hazards that may have effects in more than one State." ${ }^{302}$ Since Congress can preempt state law in any area within the scope of its power under the commerce clause, ${ }^{303}$ it can preempt state common law in the areas of air, water, and hazardous waste pollution control.

\section{Tenth Amendment Limitations}

Assuming that the federal pollution control statutes are authorized by the commerce clause, it is also necessary to consider whether the tenth amendment ${ }^{304}$ prohibits congressional preemption of state com-

300 See, e.g., 42 U.S.C.A. $§ 6901$ (a)(4), (c)(3) (West 1983 \& Supp. 1985) (RCRA); 42 U.S.C. § 7401(a)(1), (a)(4) (Clean Air Act); H.R. REP. No. 1146, 91st Cong., 2d Sess. 15 (1970), reprinted in 1970 U.S. Code Cong. \& AD. News 5356, 5371 (Clean Air Act).

so1 See, e.g., Dressman v. Costle, 22 Env't Rep. Cas. (BNA) 1707, 1714 (6th Gir. 1985) (congressional regulation of air pollution authorized by commerce clause); Sierra Club v. EPA, 540 F.2d 1114, 1139-40 (D.C. Cir. 1976) (upholding validity of EPA regulations issued under Clean Air Act provisions designed to prevent the significant deterioration of air quality in areas with clean air), cert. denied, 430 U.S. 959 (1977); United States v. Ashland Oil \& Transp. Co., 504 F.2d 1317, 1320 (6th Cir. 1974) (upholding 1972 amendments to the Glean Air Act under the commerce clause); South Terminal Corp. v. EPA, 504 F.2d 646, 677-78 (1st Cir. 1974) (Congress has the authority under the commerce clause to regulate local transportation activities that generate air pollution.); $c f$. Palila v. Hawaii Dep't of Land \& Natural Resources, 471 F. Supp. 985, 994-95 (D. Hawaii 1979) (holding that neither the tenth nor eleventh amendments restrict enforcement of the Endangered Species Act because Congress has the power to implement valid treaties, regulate commerce, and to abrogate state immunity).

302452 U.S. at 282 (citing United States v. Byrd, 609 F.2d 1204, 1209-10 (7th Cir. 1979); Bethlehem Steel Corp. v. Train, 544 F.2d 657, 663 (3d Cir. 1976), cert. denied, 430 U.S. 975 (1977); District of Columbia v. Train, 521 F.2d 971, 988 (1975), vacated and remanded on other grounds sub nom. EPA v. Brown, 431 U.S. 99 (1977); Pennsylvania v. EPA, 500 F.2d 246, 259 (3d Cir. 1974); United States v. Bishop Processing Co., 287 F. Supp. 624 (D. Md. 1968), affd, 423 F.2d 469 (4th Cir.), cert. denied, 398 U.S. 904 (1970)); see also F. Anderson, D. MANDELKER \& A. TARLOCK, supra note 60, at 347 (federal water pollution control legislation authorized by Congress's broad power to regulate interstate commerce); Stewart, Pyramids of Sacrifice, supra note 67, at 1226-28 (recognizing the power of Congress to regulate environmental hazards).

${ }^{303}$ See FERC v. Mississippi, 456 U.S. 742, 759-60 (1982).

sos The tenth amendment provides that the "powers not delegated to the United States by the Constitution, nor prohibited by it to the States, are reserved to the States 
mon-law remedies for harms caused by pollution. ${ }^{305}$ In its 1976 decision in National League of Cities $v$. Usury, ${ }^{308}$ the Court struck down a federal statute extending federal minimum wage and hour regulations to state and local government employees. ${ }^{307}$ The Court held that the statute violated the tenth amendment by impermissibly infringing upon state sovereignty. ${ }^{308}$ In a series of subsequent cases, ${ }^{309}$ however, the Court increasingly narrowed the scope of the National League of Cities limitations on Congress's commerce clause authority. Finally, in early 1985, the Court overruled National League of Cities in Garcia v. San Antonio Metropolitan Transit Authority. ${ }^{310}$ At least temporarily, the Court appears to have removed in large part whatever affirmative limitations on federal commerce clause authority have been derived from the tenth amendment.

The Court in Garcia revisited the issue of "the manner in which the Constitution insulates States from the reach of Congress's power under the Gommerce Clause."311 The Court declared that it had "no license to employ freestanding conceptions of state sovereignty when measuring congressional authority under the Commerce Clause."\$12 According to the Court, any restraints imposed on federal power over the states are "inhere[nt] principally in the workings of the National Government itself, rather than in discrete limitations on the objects of federal authority. State sovereign interests, then, are more properly

respectively, or to the people." U.S. CoNST. amend. X.

${ }^{305}$ The Supreme Court has not decided whether the Clean Air or Water Acts, RCRA, or CERCLA are invalid on tenth amendment grounds. See Note, Non-Statutory Pollution Remedies in the Wake of Gity of Milwaukee v. Illinois, 35 RUTGERS L. REv. 595, 625 (1983).

306426 U.S. 833 (1976).

307 See id. at 851.

${ }^{308}$ See id. at 845-52. In subsequent tenth amendment cases the Court applied a three-part test to determine whether the statute violated the tenth amendment: whether the statute regulated the states as states; whether it regulated an attribute of state sovereignty; and whether it directly impaired the states' ability to structure integral operations in areas of traditional governmental functions. See, e.g., EEOC v. Wyoming, 460 U.S. 226, 236-39 (1983); FERC v. Mississippi, 456 U.S. 742, 763 n.28, 769-70 (1982); United Transp. Union v. Long Island R.R., 455 U.S. 678, 684 (1982); Hodel v. Virginia Surface Mining \& Reclamation Ass'n, 452 U.S. 264, 287-88 (1981). Even if a litigant satisfies all three parts of the test, a tenth amendment attack will not succeed if the nature of the federal interest advanced justifies state submission. EEOC v. Wyoming, 460 U.S. at 238,242 n.17.

300 See EEOC v. Wyoming, 460 U.S. 226 (1983); FERC v. Mississippi, 456 U.S. 742 (1982); United Transp. Union v. Long Island R.R., 455 U.S. 678 (1982); Hodel v. Virginia Surface Mining \& Reclamation Ass'n, 452 U.S. 264 (1981).

${ }_{310} 105$ S. Ct. 1005 (1985).

311 Id. at 1016. Garcia involved the applicability of the minimum wage and overtime requirements of the Fair Labor Standards Act, 29 U.S.C. $\$ \S 201-219$ (1982), to a municipally owned and operated mass transit system.

s12 Garcia, 105 S. Ct. at 1017. 
protected by procedural safeguards inherent in the structure of the federal system than by judicially created limitations on federal power."313 The Constitution's "built-in restraints" on Congress's commerce clause authority are provided through state participation in the process of enacting federal law; "[t]he political process ensures that laws that unduly burden the States will not be promulgated."314 The Court refused to identify or define any "affirmative [constitutional] limits" on the commerce clause authority. ${ }^{315}$ It appears, however, that federal regulation of the states would have to "devour the essentials" "316 or be "destructive of state sovereignty"317 before it would violate the tenth amendment.

It is difficult to imagine that the Court that decided Garcia would find that a federal statute preempting state common-law remedies for harm caused by pollution violated the tenth amendment. First, such a statute would not even give rise to the concerns at issue in National League of Cities and Garcia. Whatever tenth amendment constraints on congressional commerce clause powers remain after Garcia do not apply to congressional regulation of private activities affecting interstate commerce $^{\mathbf{3 1 8}}$ Eliminating a private person's right to seek redress for harm caused by pollution through state common-law remedies would impose a restraint primarily on private activity, and therefore would not raise any tenth amendment concerns. ${ }^{319}$ Second, under the analysis

s13 Id. at 1018; see also id. ("TT]he principal means chosen by the Framers to ensure the role of the States in the federal system lies in the structure of the Federal Government itself."); id. at 1019 ("[T]he fundamental limitation that the constitutional scheme imposes on the Commerce Clause to protect the 'States as States' is one of process rather than one of result.").

314 Id. at 1020.

s1s See id.

s16 Id. at 1016 (quoting Maryland v. Wirtz, 392 U.S. 183, 205 (1968) (Douglas, J., dissenting)).

317 Id. at 1020. (1981):

s18 See Hodel v. Virginia Surface Mining \& Reclamation Ass'n, 452 U.S. 264

We began [in National League of Cities] by drawing a sharp distinction between congressional regulation of private persons and businesses "necessarily subject to the dual sovereignty of the government of the Nation and of the State in which they reside," [National League of Cities, 426 U.S. at 845 ], and federal regulation "directed, not to private citizens, but to the States as States" [id.]. As to the former, we found no Tenth Amendment impediment to congressional action.

Id. at 286; see also EEOC v. Wyoming, 460 U.S. 226, 237 n.10 (1983) (" "A wealth of precedent attests to congressional authority to displace or preempt State laws regulating private activity affecting interstate commerce when the laws conflict with federal law ... .") (quoting Virginia Surface Mining, 452 U.S. at 290).

319 Cf. Duke Power Co. v. Carolina Envtl. Study Group, 438 U.S. 59, 84 n.27 (1978) (rejecting the claim that federal statutory limitation on the common-law liability 
pursued by the Garcia Court, even if an act preempting state commonlaw remedies is viewed as federal regulation of the state judicial system, ${ }^{320}$ the law would never have been enacted by Congress if it truly imposed "undu[e] burden[s]" on the states. ${ }^{321}$ Third, even if the tenth amendment does impose affirmative substantive constraints on Congress, the preemption of state common-law remedies in a limited area would not appear sufficiently "destructive of state sovereignty"322 to exceed those constraints. Although the states' control over the dockets of their courts involves an attribute of state sovereignty, the preemption of common-law remedies for harms caused by pollution is arguably less intrusive on state sovereignty than statutes, already upheld by the Court, that impose affirmative obligations on states to consider or apply federally prescribed standards. ${ }^{323}$ The Court has stated that the federal government has the authority to enlist a branch of state government, including the judiciary, to further federal ends. ${ }^{324} \mathrm{~A}$ prohibition

of the private nuclear power industry impermissibly encroached on state government interests). Congressional preemption of state common-law remedies could also be viewed, however, as a restriction on the state judicial system, whereby Congress attempts to restrict the judiciary's ability to provide relief for certain types of harm. In Silkwood v. Kerr-McGee Corp., 104 S. Ct. 615 (1984), the Court, in deciding that the Atomic Energy Act, 42 U.S.C. $\S \S 2011-2284$ (1982), did not preempt the recovery of punitive damages by a person injured through exposure to radioactive materials, demonstrated a reluctance to conclude that state common-law remedies were preempted. See 104 S. Ct. at 625-26. The Court's holding, however, was based on the conclusion that Congress did not intend to preempt state court punitive damage awards, not that it lacked the authority to do so. See id. at 621-26.

s20 See supra note 319.

321 See Garcia, 105 S. Ct. at 1020.

s22 Id. The provisions of the federal pollution control statutes requiring states either to adopt certain regulatory programs (for example, the Clean Air Act's requirement that states adopt plans for achieving the national ambient air quality standards, 42 U.S.C. $\$ 7410(a)$ ), or have such programs imposed on their private citizens and businesses by the federal EPA, seem to involve a more direct threat to "the essentials of state sovereignty," " $105 \mathrm{~S}$. Ct. at 1016 (quoting Maryland v. Wirtz, 392 U.S. 183, 205 (1968) (Douglas, J., dissenting)), than would the preemption of state common-law remedies for injured individuals. Even these provisions, however, have been able to withstand tenth amendment attack. See, e.g., Hodel v. Virginia Surface Mining \& Reclamation Ass'n, 452 U.S. 264, 289 n.30 (1981); United States v. District of Columbia, 654 F.2d 802 (D.C. Cir.) (A federal district court order selecting site for sewage treatment plant and ordering county to budget funds to build the plant does not violate the tenth amendment.), cert. denied, 454 U.S. 1082 (1981); Sierra Club v. EPA, 540 F.2d 1114, 1140 (D.C. Cir. 1976) (EPA regulations under the Clean Air Act compelling states to modify their implementation plans to prevent significant deterioration of air quality in areas with clean air do not violate the tenth amendment.), cert. denied, 430 U.S. 959 (1977). For an analysis of Congress's ability in light of National League of Cities to conscript state resources for implementation of federal environmental policy, see generally Stewart, Pyramids of Sacrifice, supra note 67.

s2s See, e.g., FERG v. Mississippi, 456 U.S. 742, 765 (1982).

324 See id. at 762; see also Testa v. Katt, 330 U.S. 386 (1947) (upholding federal statute that created treble damages action for violation of federal price control regula- 
on the state judiciary's authority to hear a limited class of cases, if rationally related to the goal of regulating interstate commerce, ${ }^{325}$ therefore would not appear to be "destructive of state sovereignty."326 That state courts have traditionally provided remedies for injured individuals in common-law tort cases does not in itself restrict Congress's commerce clause power to preempt state common law. ${ }^{327}$ "[I]t has always been the law that state legislative and judicial decisionmakers must give preclusive effect to federal enactments concerning nongovernmental activity, no matter what the strength of the competing local interests. ${ }^{3328}$

\section{Due Process Limitations}

The due process clause of the fifth amendment might present a more formidable obstacle to congressional preemption of all state common-law remedies for harms caused by pollution than would the tenth amendment. ${ }^{329}$ The federal pollution control statutes do not include a mechanism for private recovery of compensatory damages. ${ }^{330}$ If Congress preempted all private damage recoveries under both federal and state common law, then a person whose property has been damaged or whose health has been impaired as a result of exposure to pollutant discharges would have no forum in which to seek compensation from the responsible polluter. ${ }^{331}$ The elimination of all avenues of monetary redress might constitute a deprivation of liberty or property in violation

tions and vested jurisdiction to hear such actions in state as well as federal courts).

${ }^{325}$ See Virginia Surface Mining, 452 U.S. at 291.

${ }^{328}$ Garcia, 105 S. Ct. at 1020.

${ }^{327}$ Cf. FERC v. Mississippi, 456 U.S. 742, 759 (1982) (Congress can displace state regulation even though this serves to curtail or prohibit the states' prerogatives to make legislative choices in areas the states consider important.); Virginia Surface Mining, 452 U.S. at 291-92 (Congress does not invade areas reserved to the states simply because it exercises its authority under the commerce clause in a manner that displaces the exercise of state police powers.); id. at 292 (It would be a "radical departure" from long-established precedent to hold that the tenth amendment prohibits Congress from displacing state police power laws regulating private activity.).

${ }_{328}$ FERC v. Mississippi, 456 U.S. 742, 766 (1982) (emphasis added).

s29 The fifth amendment provides, in part, that "[n]o person shall . . . be deprived of life, liberty, or property, without due process of law; nor shall private property be taken for public use, without just compensation." U.S. CoNST. amend. V.

s3o See supra notes 88-91 and accompanying text.

331 A state could enact a statutory or administrative mechanism for private damage recovery. A court construing the savings clauses of the statutory citizen suit provisions as not preserving state common-law remedies, however, would have a difficult time concluding that state statutory remedies for individual compensation survived enactment of the statutes. This Article contends that Congress intended to preempt neither state common-law nor statutory remedies. See infra text accompanying notes 363-468 \& 483-523. 
of the due process clause.

The Supreme Court rejected a similar contention in Duke Power Co. v. Carolina Environmental Study Group, ${ }^{332}$ in a challenge to the constitutionality of the Price-Anderson Act. ${ }^{333}$ The Act limits the liability of privately owned nuclear power plants licensed by the federal government to $\$ 560$ million in the event of a nuclear accident, such as a core meltdown. ${ }^{334}$ Residents close to a proposed nuclear plant contended, and the trial court agreed, that the Act violated the due process clause because the amount available for compensation of injured individuals is not rationally related to the potential losses from an accident, ${ }^{335}$ and because those injured are not provided with a satisfactory quid pro quo for the common-law rights of recovery abrogated by the statute. $^{336}$

The Supreme Court disagreed, stating that Congress could choose to limit liability in order to encourage the private development of atomic power. ${ }^{337}$ Although the Court stated that "it is not at all clear that the Due Process Clause in fact requires that a legislatively enacted compensation scheme either duplicate the recovery at common law or

332438 U.S. 59 (1978).

sss Pub. L. No. 85-256, § 4, 71 Stat. 576 (1957) (current version at 42 U.S.C. $\S 2210(1982))$.

3s4 The Act requires a licensee to purchase the maximum amount of available privately underwritten public liability insurance (about $\$ 60$ million at the time of enactment in 1957) and provides that, if damages from a nuclear disaster exceed the amount of insurance coverage, the federal government will indemnify the licensee up to an additional $\$ 500$ million. See Duke Power Co., 438 U.S. at 64-65.

s3s Carolina Envtl. Study Group v. United States, 431 F. Supp. 203, 221-22 (W.D.N.C. 1977), rev'd and remanded sub nom. Duke Power Co. v. Carolina Envtl. Study Group, 438 U.S. 59 (1978). The Supreme Court applied the rational basis standard of judicial review normally applicable to economic regulations, since the Act was a "classic example" of a legislative effort to structure and accommodate "the burdens and benefits of economic life." "Duke Power Co., 438 U.S. at 83 (quoting Usery v. Turner Elkhorn Mining Co., 428 U.S. 1, 15 (1976)). Accordingly, the Act was afforded a presumption of constitutionality. See id. at 83-84.

sss Carolina Envtl. Study Group v. United States, 431 F. Supp. 203, 221-22 (W.D.N.C. 1977), rev'd and remanded sub. nom. Duke Power Co. v. Carolina Envtl. Study Group, 438 U.S. 59 (1978).

${ }^{357}$ See Duke Power Co., 438 U.S. at 88 . The Court cited several cases for the proposition that a person has no vested property interest in any rule of the common law. See, e.g., Silver v. Silver, 280 U.S. 117, 122 (1929); Second Employers' Liability Cases, 223 U.S. 1, 50 (1912). These cases, however, involved attacks on the constitutionality of statutory schemes by the parties potentially subject to the new statutory liabilities, not by persons whose common-law right to seek judicial damage awards would be altered or replaced. Moreover, none of the acts in these cases totally cut off the right to compensation of injured individuals. Rather, they limited the liability of those responsible for the injuries, in return for which the statutes cut off certain defenses (such as the fellow servant rule and assumption of risk) and established administrative mechanisms to facilitate individual recoveries. 
provide a reasonable substitute remedy,"338 it expressly left this question unsettled ${ }^{339}$ because it found that the Price-Anderson Act created "a fair and reasonable substitute." 340 Absent the statutory limitation on liability, recovery under state common law might be impossible, due to the potential barriers created by state tort law. ${ }^{341}$ The Court further relied on a 1975 amendment to the statute, which explicitly provided that in the event of a nuclear "incident," Congress itself would " "take whatever action is deemed necessary and appropriate to protect the public from the consequences" "of the disaster. ${ }^{342}$ The Court thus viewed the $\$ 560$ million amount as a floor, not a ceiling, on recovery.

No such adequate substitute for state common-law compensatory remedies exists in the federal air and water pollution and hazardous waste disposal statutes. In fact, no substitute exists at all. Generally, a person has no vested property interest in any particular common-law rule, ${ }^{343}$ and the due process clause does not forbid the abolition of common-law rights to attain a permissible legislative goal. ${ }^{344}$ Under the Constitution, however, there may be certain "core' common-law rights, including rights against trespass," which the government is not free to abrogate, "at least without a compelling showing of necessity or a provision for a reasonable alternative remedy."345 The Supreme Court has recognized that

[t]he liberty preserved from deprivation without due process included the right "generally to enjoy those privileges long recognized at common law as essential to the orderly pursuit

${ }^{\text {ss8 }}$ Duke Power Co., 438 U.S. at 88.

sse See id. at 88-91.

s40 Id. at $90-91$.

341 See id. at 91-92. The Act was intended to provide a more efficient and certain vehicle for assuring compensation in the event of a nuclear accident than was previously available under state common-law tort remedies. See id. at 89-90 (citing Hearings on H.R. 8631 Before the Joint Committee on Atomic Energy, 94th Cong., 1st Sess. 69 (1975) (statement of William A. Anders, Chairman, Nuclear Regulatory Commission)); cf. Silkwood v. Kerr-McGee Corp., 104 S. Ct. 615, 637 (1984) (Powell, J., dissenting) ("[T]he primary concern" in enacting the Price-Anderson Act "was to assure compensation for persons who suffered loss.").

342 See Duke Power Co., 438 U.S. at 90-91 (quoting 42 U.S.C. § 2210(e)).

s4s See, e.g., Munn v. Illinois, 94 U.S. 113, 134 (1877); see also cases cited supra note 337 (concluding that by necessity any designated ceiling on liability will be arbitrary).

344 See Pruneyard Shopping Center v. Robins, 447 U.S. 74, 92 (1980) (Marshall, J., concurring) (citing Silver v. Silver, 280 U.S. 117, 122 (1929)).

sts Id. at 94 (Marshall, J., concurring); see also Richards v. Washington Terminal Co., 233 U.S. 546, 553 (1914) (stating "the true rule under the Fifth Amendment . . to be that while the legislature may legalize what otherwise would be a public nuisance it may not confer immunity from action for a private nuisance of such a character as to amount to ... a taking of private property for public use"). 
of happiness by free men." ... Among the historic liberties so protected was a right to be free from, and to obtain judicial relief for, unjustified intrusions on personal security. ${ }^{346}$

Thus, a congressional attempt to preempt state common-law damage remedies for persons whose health is impaired by pollution, without providing any substitute mechanism for compensation, might conflict with the due process clause. ${ }^{347}$ Courts often construe statutes to avoid difficult constitutional questions. The due process issues raised by the preemption of state common-law compensatory remedies for harms caused by pollution therefore might convince a court to construe any ambiguities in the provisions of the Clean Air and Water Acts, RCRA, and CERCLA against the preemption of those remedies. ${ }^{348}$

${ }^{346}$ Ingraham v. Wright, 430 U.S. 651, 673 (1976) (quoting Meyer v. Nebraska, 262 U.S. 390,399 (1923)) (emphasis added). If a private party invades another private individual's common-law rights, due process may require that the victim be afforded a hearing, which would typically take the form of a common-law action for damages by the victim. See Stewart \& Sunstein, supra note 66, at 1310 n.479. The government's refusal to offer any such procedural protective mechanisms "raises the substantive due process question of the legislature's authority to abolish common law entitlements." Id.; see also id. at 1314 (The interest in bodily integrity is constitutionally entitled to government protection.). But $c f$. id. at 1311 (The government might "meet its due process obligations by punishing or redressing violations of entitlements through criminal prosecutions or other forms of public enforcement.").

${ }_{347}$ See L. TRIBE, AMERICAN Constitutional Law 45 (Supp. 1979) (The Price-Anderson Act's guarantee of further compensation if the $\$ 560$ million were insufficient "becomes the only confident [basis] for the holding [in Duke Power] that the victims of an accident [would] not [be] deprived of property, and the constitutionality of the Act may well turn on that guarantee."); cf. New York Cent. R.R. v. White, 243 U.S. 188, 201 (1917) (stating that "it perhaps may be doubted whether the State could abolish all rights of action [by injured employees against employers] on the one hand ... . without setting up something in their stead," but giving no opinion on the issue since the question was not before the Court).

s48 See, e.g., Ouellette v. International Paper Co., 602 F. Supp. 264 (D. Vt. 1985). In that case, the court analyzed three ways to interpret sections 505(e) and 510 of the Clean Water Act, 33 U.S.C. $\$ \S 1365(\mathrm{e}), 1370$, as they applied to the question whether Congress intended to preempt state common-law remedies for interstate water pollution. The court rejected the "most restrictive interpretation," 602 F. Supp. at 268, which would preserve state remedies only for pollution of waters outside of the Act's jurisdiction:

[U]nder this interpretation of the Act, a person injured by pollution of "navigable waters" would be unable to recover damages from the polluter since the Act does not provide a damage remedy for private actions. It is simply inconceivable that Congress intended to deprive a party injured by water pollution of all compensation for that injury.

Id. at 269 (citation omitted). The court also rejected a second alternative, which would preserve common-law remedies only for injuries from in-state sources. See id. The court concluded instead that "the Act authorizes actions to redress injury caused by water pollution of interstate waters through the laws of the state in which the injury occurred." Id.; see also White Lake Improvement Ass'n v. City of Whitehall, 22 Mich. App. 262, 177 N.W.2d 473, 478 n.16 (1970) (state statute interpreted as preserving 


\section{B. Principles of Federal Preemption}

Even if Congress has the authority to preempt state common-law remedies for environmental injury, the federal pollution control statutes do not displace those remedies unless Congress intended to do so. In addressing whether enactment of the Clean Water Act preempted federal common-law nuisance actions, the Court in Milwaukee II " "start[ed] with the assumption" " that it is for Congress, not the federal courts, to articulate the governing standards of federal law. ${ }^{349}$ The Court is less likely, however, to find federal preemption of state common law because it begins "with the assumption that the historic police powers of the states were not to be superseded by [federal legislation] unless that was the clear and manifest purpose of Congress." 350 Regulation of pollution-generating activities and the provision of tort remedies to compensate for personal injuries both "clearly fall[ ] within the exercise of even the most traditional concept of what is compendiously known as the police power."351 Absent a clear manifestation of congressional intent to preempt state common-law remedies, the presumption of continuing state authority cannot be rebutted, and the states, through their judicial systems, will be free to regulate pollution emissions and to provide compensatory remedies for harms caused by pollution. ${ }^{\mathbf{3 2}}$

The Supreme Court has recognized two general ways in which Congress can preempt state law. First, Congress can occupy a given field to the exclusion of any state law falling within that field. ${ }^{353}$ The courts have little difficulty finding preemption when Congress explicitly manifests its intent to occupy a field, either in the statute or its legislative history. The courts have also recognized implicit congressional intent to occupy a field. Such an intent arises (1) when the scheme of federal regulation is so pervasive that a court can reasonably infer that

judicial remedies for injury caused by municipally discharged sewage to avoid the "serious issue" as to the constitutionality of the statute that would be presented by a contrary interpretation); Urie v. Franconia Paper Corp., 107 N.H. 131, 134, 218 A.2d 360,362 (1966) (refusing to interpret state statute to bar equitable relief in a private nuisance action against a paper manufacturer, because "such legislation would constitute taking private property for a non-public purpose").

349 451 U.S. at 317 (quoting Rice v. Santa Fe Elevator Corp., 331 U.S. 218, 230 (1947)).

sso Id. at 316.

s51 Rice v. Santa Fe Elevator Corp., 331 U.S. 218, 230 (1947).

s52 See Huron Portland Cement Co. v. City of Detroit, 362 U.S. 440, 442 (1960); Ferebee v. Chevron Chem. Co., 736 F.2d 1529, 1542 (D.C. Cir.), cert.'rdenied, 105 S. Ct. 545 (1984).

353 See Huron Portland Cement Co. v. City of Detroit, 362 U.S. 440, 442 (1960); Ferebee v. Chevron Chem. Co., 736 F.2d 1529, 1542 (D.C. Cir.), cert. denied, 105 S. Ct. 545 (1984). 
Congress left no room for the states to supplement it; ${ }^{364}$ (2) when the federal statute touches a field in which the federal interest is so dominant that enforcement of state laws on the same subject must be assumed to be precluded; $; 50$ or (3) when the object sought to be obtained by the federal law and the character of obligations imposed by it reveal the purpose to preclude state law. ${ }^{358}$ The burden of proving congressional intent to preempt state law is on the party contending that state law has been displaced, ${ }^{357}$ an allocation that reflects the courts' reluctance to preempt state law.

Second, when Congress has not occupied a particular field, state law may be preempted to the extent that it "actually conflicts with a ... federal statute." ${ }^{\text {s68 }}$ The most obvious type of conflict arises where it is physically impossible to comply with both the federal and state regulations. ${ }^{359}$ A conflict can also arise where the state law stands as an obstacle to the accomplishment of congressional objectives. ${ }^{360}$ The courts' reluctance to oust state jurisdiction is manifested in their refusal to seek out conflicts between federal and state regulation when none clearly exists. ${ }^{361}$ Rather than completely oust state law, they try to rec-

s84 See, e.g., Silkwood v. Kerr-McGee Corp., 104 S. Ct. 615, 621 (1984); Milwaukee II, 451 U.S. at 316 (citing Ray v. Atlantic Richfield Co., 435 U.S. 151, 157 (1978)).

sss "When the federal government occupies a given field or an identifiable portion of it . . . the test of preemption is whether 'the matter on which the State asserts the right to act is in any way regulated by the federal government." "Pacific Gas \& Elec. Co. v. State Energy Resources Conservation \& Dev. Comm'n, 461 U.S. 190, 203-04 (1983) (citing Rice v. Sante Fe Elevator Corp., 331 U.S. 218, 236 (1947)).

${ }_{358}$ See Pacific Gas \& Elec. Co. v. State Energy Resources Conservation \& Dev. Comm'n, 461 U.S. 190, 203-04 (1983); Ray v. Atlantic Richfield Co., 435 U.S. 151, 157 (1978); Chevron U.S.A., Inc. v. Hammond, 726 F.2d 483, 488 (9th Cir. 1984), cert. denied, $105 \mathrm{~S}$. Ct. 2686 (1985). The tests for finding implicit congressional intent are more easily stated than applied. The courts consider the following factors, among others, in determining whether Congress has occupied a given field to the exclusion of the states: comprehensiveness of federal regulations; consideration of state police power; congressional intent that there be collaborative federal/state efforts to act in the given field; the need for uniform regulation; and the history of regulation of the subject matter. See id. at 486.

ss7 See Silkwood v. Kerr-McGee Corp., 104 S. Ct. 615, 625 (1984).

s5s Ray v. Atlantic Richfield Co., 435 U.S. 151, 158 (1978).

ss9 See, e.g., Silkwood v. Kerr-McGee Corp., 104 S. Ct. 615, 621 (1984); Pacific Gas \& Elec. Co. v. State Energy Resources Conservation \& Dev. Comm'n, 461 U.S. 190, 204 (1983); Ray v. Atlantic Richfield Co., 435 U.S. 151, 158 (1978).

${ }^{\text {seo }}$ See Silkwood v. Kerr-McGee Corp., 104 S. Ct. 615, 621 (1984); Pacific Gas \& Elec. Co. v. State Energy Resources Conservation \& Dev. Comm'n, 461 U.S. 190, 204 (1983); Ray v. Atlantic Richfield Co., 435 U.S. 151, 158 (1978); Ghevron U.S.A., Inc. v. Hammond, 726 F.2d 483, 495 (9th Cir. 1984), cert. denied, 105 S. Ct. 2686 (1985).

s61 See, e.g., Huron Portland Cement Co. v. City of Detroit, 362 U.S. 440, 446 (1960); Chevron U.S.A., Inc. v. Hammond, 726 F.2d 483, 499 (9th Cir. 1984) (citing Exxon Corp. v. Governor of Maryland, 437 U.S. 117, 130 (1978); Seagram \& Sons v. Hostetter, 384 U.S. 35, 45 (1966)), cert. denied, 105 S. Ct. 2686 (1985). 
oncile the operation of the two statutory schemes. ${ }^{362}$

\section{G. Preemption for Intrastate Purposes}

The Supreme Court in Milwaukee II declined to decide whether the enactment of the 1972 amendments to the Clean Water Act preempted state common-law remedies for harm caused by pollution. ${ }^{363}$ The Court indicated, however, that it would be far more reluctant to conclude that the federal statute preempted state common law than that it preempted federal common law. ${ }^{364}$ This section analyzes whether the enactment of the Glean Air and Water Acts has preempted state common-law remedies for an individual injured in one state by pollutant discharges originating in the same state. The next section considers the same question when a person is injured by pollution from an out-ofstate source. The preemptive effects of RGRA and CERCLA in both the intrastate and interstate contexts are analyzed in a subsequent section. ${ }^{365}$

The analysis of whether the Clean Air and Water Acts preclude the states from regulating dischargers or compensating those injured by

${ }^{362}$ See Chevron U.S.A., Inc. v. Hammond, 726 F.2d 483, 496 (9th Cir. 1984) (citing Merrill Lynch, Pierce, Fenner \& Smith v. Ware, 414 U.S. 117, 126 (1973)), cert. denied, 105 S. Ct. 2686 (1985); see also Silkwood v. Kerr-McGee Corp., 104 S. Ct. 615, 626 (1984) (noting that state law is preempted only to the extent that it actually conflicts with federal law, and finding, therefore, that state-imposed punitive damages were not preempted by a potential federal fine).

${ }^{363}$ See 451 U.S. at 310 n.4. The district court had ruled that Illinois was entitled to injunctive relief under both federal and state common law. The court of appeals refused to address Illinois' state common-law allegations, since "it is federal common law and not state statutory or common law that controls in this case." Id. (citing Illinois v. City of Milwaukee, 599 F.2d 155, 177 n.53 (7th Cir. 1979), rev'd, 451 U.S. 304 (1981)). Illinois filed a separate petition for certiorari on the state common-law preemption issue. See Milwaukee II, 451 U.S. at 310 n.4. The Court denied that petition after its decision in Milwaukee II.

set See Milwaukee II, 451 U.S. at 316; see also supra text accompanying notes 350-52 (explaining that the Court assumes that Congress did not intend to preempt state law absent a showing of a clear intent to do so).

${ }^{365}$ The preemptive effect of RCRA and GERCLA on remedies for injuries emanating from the handling, treatment, storage, or disposal of hazardous wastes is discussed in section E of this Part. See infra notes 483-523 and accompanying text. The analysis of the preemptive effect of these two laws differs from the Clean Air and Water Acts analysis for three reasons. First, Congress has delegated to the federal courts the authority to create a body of federal common law concerning certain hazardous waste issues. Second, CERCLA contains a provision expressly preempting certain state common-law remedies for interstate harms. Third, Congress has expressed particular concern over the need for uniformity in the hazardous waste area. Nevertheless, in most cases the result is the same under the hazardous waste disposal acts as under the air and water pollution statutes. Congress did not intend to preempt state common-law regulatory or compensatory remedies, except for certain remedies for harm caused by interstate activities covered by CERCLA. 
pollution should begin with the statutory language. Neither Act expressly preempts state common-law remedies. In fact, it appears that the statutes expressly preserve such remedies. The savings clause of the citizen suit provision of the Glean Water Act provides that "[n]othing in this section shall restrict any right which any person . . . may have under any statute or common law to seek enforcement of any effluent standard or limitation or to seek any other relief."38s In a pre-Milwaukee II decision, the Court of Appeals for the Sixth Circuit concluded that this provision "recognize[s] the continuing validity of state common law nuisance actions."

The provisions of the savings clause are not necessarily dispositive, however, on the preemption issue. Under the theory espoused by the Court in Milwaukee II, the savings clause takes no position on the continuing availability of state common-law remedies. It simply states that "[n]othing in this section"- that is, the citizen suit provisions of the statute-restricts state common-law rights, whereas the rest of the statute might preempt these rights. ${ }^{368}$ Yet this contention is inconsistent with the legislative history of the Clean Water Act's citizen suit provision. According to a Senate Committee Report, the citizen suit provision "would specifically preserve any rights or remedies under any other law." ${ }^{\text {"368 }}$ This statement reflects more than a congressional refusal

sse 33 U.S.C. $\S 1365$ (e) (emphasis added). The language of the Clean Air Act's citizen suit provision is similar. See 42 U.S.C. $\$ 7604(\mathrm{e})$; see also 42 U.S.C. $\S 300$ j8(e) (1982) (the Safe Drinking Water Act).

${ }^{387}$ Committee for the Jones Falls Sewage Sys. v. Train, 539 F.2d 1006, 1009 n.9 (4th Cir. 1976). In the National Sea Clammers case, the Supreme Court indicated that the phrase "any effluent standard or limitation" in the Clean Water Act's savings clause could include state " 'effluent limitations' imposed as a result of court decrees under the common law of nuisance." 453 U.S. at $16 \mathrm{n} .26$. In Milwaukee II, the Court rejected the assertion that this savings clause refers to "the more limited federal common law as opposed to the more routine state common law." 451 U.S. at 329 (citing Committee for Jones Falls, 539 F.2d 1006, 1009 n.9 (4th Cir. 1976)). This statement, especially its citation (with apparent approval) of footnote nine of the Committee for Jones Falls case, seems to reflect the Court's view that the savings clause of the Clean Water Act's citizen suit provision expressly preserves state common-law remedies. But see Comment, supra note 90, at 393 (The Court's recognition of state common law resulted from its efforts to construe "common law" to exclude federal common law and did not constitute an affirmative recognition of state common-law relief.).

${ }^{368}$ Cf. Milwaukee II, 451 U.S. at 329 (The citizen-suit savings clause "means only that the provision of such suit does not revoke other remedies.").

${ }^{369}$ S. REP. No. 414, 92d Cong., 1st Sess. 81 (1971), reprinted in 1972 U.S. Code Cong. \& AD. NEws 3668, 3746. The Senate Committee stated further that "if damages could be shown, other remedies would remain available." Id., quoted in Ouellette v. International Paper Co., 602 F. Supp. 264, 269 (D. Vt. 1985); cf. H.R. REP. No. 1491, 94th Cong., 2d Sess., pt. 1, at 69 (1976), reprinted in 1976 U.S. CoDE CoNG. \& AD. NEwS 6238, 6308 (construing RCRA's citizen suit provision); H.R. REP. No. 361, 92d Cong., 1st Sess. 23 (1971) (Common-law rights are not "in any way restrict[ed] or supersede[d]" by passage of the Marine Protection, Research, and 
to take a position on the state common-law preemption issue; it is an affirmative recognition that state common-law rights and remedies were meant to survive enactment of the federal statute.

Other statutory provisions support this interpretation of the citizen suit provision's savings clause. Section 510 of the Glean Water Act, for example, provides that nothing in the Act "shall . . . preclude or deny the right of any state . . . to adopt or enforce (A) any standard or limitation respecting discharges of pollutants, or (B) any requirement respecting control or abatement of pollution," provided that the state standards or requirements are at least as stringent as any applicable

Sanctuaries Act of 1971.); S. REP. No. 451, 92d Cong., 1st Sess. 23-24 (1971), reprinted in 1971 U.S. Code CoNG. \& AD. NEwS 4234, 4248; H.R. REP. No. 1783, 91st Cong., 2d Sess. 56 (1970), reprinted in 1970 U.S. Code Cong. \& AD. NEwS 5356, 5388 (Common-law rights are "not affected" by the enactment of the Clean Air Act.).

The argument that the legislative history of the citizen suit provisions reflects Congress's intent to preserve state common-law remedies is not a complete answer to the interpretation of those provisions set forth in Milwaukee II. The savings clause in the Clean Water Act's citizen suit provision draws no distinction between state and federal common law, see supra note 133, nor does the legislative history. See, e.g., S. REP. No. 414, 92d Cong., 1st Sess. 81 (1971), reprinted in 1972 U.S. CodE Cong. \& AD. NEws 3668,3747 . Accordingly, if the clause is construed to preserve state common law, then it should also preserve federal common law. It is precisely this contention, of course, that the majority of the Court rejected in Milwaukee II. These apparently conflicting interpretations of the savings clause, however, can be reconciled by taking into account the assumptions with which the Court begins its preemption analysis. The Court assumes that federal law is pronounced by Congress rather than the courts. Therefore, the citizen suit provision, whose language is unclear, is interpreted as taking no position on the continuing availability of federal common law. The Court then analyzes the rest of the statute to support its conclusion that the statute's comprehensive nature displaces federal common law. When the issue involves preemption of state common law, the Court assumes that the lawmaking authority of the states was not superseded. See Milwaukee II, 451 U.S. at 316. Given this presumption, the ambiguous statutory language should be construed in favor of retaining state law. Thus, the savings clause preserves state common law, a result that is fortified by S. REP. No. 414, supra. See Ouellette v. International Paper Co., 602 F. Supp. 264, 268-70 (D. Vt. 1985); see also Chappell v. SCA Serv., 540 F. Supp. 1087, 1100 (C.D. Ill. 1982) (holding that the savings provision of the Toxic Substances Control Act's citizen suit provision, 15 U.S.C. $\$ 2619$ (c)(3) (1982), preserves state common-law nuisance actions for damages); Ginn v. Consolidation Coal Co., 107 Ill. App. 3d 564, 437 N.E.2d 793, 796 (1982) (citing Milwaukee II, 451 U.S. at 328, for the proposition that the savings clause in the citizen suit provision of the Surface Mining Control and Reclamation Act of 1977,30 U.S.C. $\S 1270$ (e) (1982), "is an express indication that [the statute] should not be read as limiting other remedies which might exist"); New York v. Monarch Chems., Inc., 111 Misc. 2d 343, 349, 443 N.Y.S.2d 967, 969 (Sup. Ct. 1981) (no clear intent in Safe Drinking Water Act, Toxic Substances Control Act, or RCRA to preempt state regulation of drinking water or toxic chemicals), modified, 90 App. Div. 2d 907, 456 N.Y.S.2d 867 (1982); cf. Illinois v. City of Milwaukee, 731 F.2d 403, 414 (7th Gir. 1984) (The savings clause in section 505(e) of the Clean Water Act, 33 U.S.C. $\S 1365(\mathrm{e})$, "may well preserve a right under statutes or the common law of the state within which a discharge occurs" to enforce its own law.), cert. denied, $105 \mathrm{~S}$. Ct. 979 (1985). 


\section{federal requirement. ${ }^{370}$ The Supreme Court suggested in Milwaukee II} that this provision may authorize state courts to establish more stringent standards through state nuisance laws. ${ }^{371}$

If the statutory language is ambiguous and neither expressly preserves nor preempts state common-law remedies, one must determine whether Congress implicitly occupied the fields of air and water pollution to the exclusion of the states. A finding that Congress implicitly occupied the field is directly contradicted by provisions of the federal pollution statutes that authorize state standards more stringent than those in the federal regulations. ${ }^{\mathbf{3 7 2}}$ Several courts have held that the federal statutes establish only a minimum federal level of pollution control, which the states may exceed by establishing more stringent controls on sources located within their borders. ${ }^{373}$ Implicit occupation of

s70 33 U.S.C. $\S 1370(1)$. Other federal statutes contain similar provisions concerning state authority. See, e.g., 42 U.S.C. $\S 300 \mathrm{~g}-3$ (e) (1982) (Safe Drinking Water Act); 42 U.S.C.A. $\& 6929$ (West 1983 \& Supp. 1985) (RCRA); 42 U.S.C. $\S 7416$ (Glean Air Act); 42 U.S.C. \$ 9614(a) (GERCLA). If section 510 of the Clean Water Act covers more stringent state common law as well as statutory standards, see infra text accompanying note 371 , then the statutory reference to "requirement[s] respecting control or abatement of pollution" would permit a court to issue an injunction limiting or prohibiting discharges, even if those discharges comply with a permit issued under federal law. See S. REP. No. 414, 92d Cong., 1st Sess. 81, reprinted in 1972 U.S. Cone ConG. \& AD. News 3668, 3746-47 ("Compliance with requirements under this Act would not be a defense to a common law action for pollution damages.").

s71 See 451 U.S. at 328; see also Illinois v. City of Milwaukee, 731 F.2d 403, 413 n.6 (7th Cir. 1984) (noting the Court's suggestion in Milwaukee II that section 510 of the Clean Water Act "may refer to effluent limitations imposed as a result of court decrees under the common law of nuisance"), cert. denied, 105 S. Ct. 979 (1985).

s72 See supra notes $370-71$ and accompanying text. The statutes also contain a series of policy pronouncements indicating congressional intent to "recognize, preserve, and protect the primary responsibilities and rights of States to prevent, reduce, and eliminate pollution." 33 U.S.G. \$ 1251(b) (Clean Water Act), cited in Ouellette v. International Paper Co., 602 F. Supp. 264, 268 (D. Vt. 1985); see also 42 U.S.C.A. $\S \S 6901(\mathrm{a})(4), 6902(8)$ (West 1983 \& Supp. 1985) (RCRA); 42 U.S.C. $\S 7401(\mathrm{a})(3)$ (Glean Air Act); cf. 33 U.S.C. $\S 1311(\mathrm{~b})(1)(\mathrm{C})$ (requiring that discharges from point sources comply with state effluent limitations that are more stringent than the federal limitations).

${ }^{373}$ See Illinois v. City of Milwaukee, 731 F.2d 403, 409 (7th Cir. 1984) (dictum), cert. denied, 105 S. Ct. 979 (1985); Chevron U.S.A., Inc. v. Hammond, 726 F.2d 483, 489 (9th Cir. 1984) (When Congress enacted the Clean Water Act, it encouraged a federal-state partnership for the control of water pollution with respect to waters within the states' jurisdiction.) (citing Pacific Legal Found. v. Costle, 586 F.2d 650, 657 (9th Cir. 1978), rev'd on other grounds, 445 U.S. 198 (1980)), cert. denied, 105 S. Ct. 2686 (1985). In Ferebee v. Chevron Chem. Co., 736 F.2d 1529 (D.C. Cir.), cert. denied, 105 S. Ct. 545 (1984), the circuit court stated that federal legislation concerning control of hazards created by production and use of pesticides

has traditionally occupied a limited role as the floor of safe conduct; before transforming such legislation into a ceiling on the ability of states to protect their citizens, and thereby radically adjusting the historic federal-state balance, United States v. Bass, 404 U.S. 336, 349 (1971), courts should wait for a clear statement of congressional intent to work such an altera- 
the field of intrastate air and water pollution, moreover, cannot be based on a dominant federal interest that precludes enforcement of state laws on the same subject. The air and water pollution control statutes recognize the "primary responsibilities and rights of the states" to control and prevent pollution. ${ }^{374}$ Congress authorized the states to adopt and enforce standards more stringent than those set by the EPA ${ }^{375}$ In accordance with these provisions, the courts have held that there is no compelling need for federal uniformity in the control of intrastate air and water pollution. ${ }^{376}$

Preemption of state law, however, need not be based on occupation of the relevant field. State law is also preempted if it conflicts with federal law. But the displacement of state common-law remedies for intrastate harms caused by air and water pollution is no more supported by the conflict branch of preemption analysis than it is by the occupation branch. It is not physically impossible to comply with both the EPA's regulations setting air or water pollutant minimum standards and a state court's decree specifying different standards or shutting down a pollutant source. The polluter need only comply with the more stringent of the two sets of standards, and it will also be in compliance with the more lenient controls. ${ }^{377}$ Nor is it impossible to adhere

tion. The Supreme Court has often counselled such hesitance.

Id. at 1543; see also People ex rel. Scott v. United States Steel Corp., 40 Ill. App. 3d $607,611,352$ N.E.2d 225, 228-29 (1976) (States may impose pollution controls that exceed federal standards.); Metropolitan Sanitary Dist. v. United States Steel Corp., 30 III. App. 3d 360, 371, 332 N.E.2d 426, 434 (1975) (The language in the Clean Water Act explicitly allows states to enforce controls more stringent than the federal standards.), cert. denied, 424 U.S. 976 (1976).

374 See supra note 372.

325 See supra notes $370-71$ and accompanying text.

378 See, e.g., Chevron U.S.A., Inc. v. Hammond, 726 F.2d 483, 491 (9th Cir. 1984) ("[T]here is no compelling need for uniformity in the regulation of pollutant discharges ... [and] there is a positive value in encouraging the development of local pollution control standards stricter than the federal minimums."), cert. denied, $105 \mathrm{~S}$. Ct. 2686 (1985); id. at 495 ("Congress did not implicitly intend to occupy the field of regulating discharges of pollutants from tankers into a state's territorial waters."); McCastle v. Rollins Envtl. Serv., 514 F. Supp. 936, 941 (M.D. La. 1981) (Congress has not concluded that there is an overriding federal concern in the area of air pollution.); see also Committee for the Jones Falls Sewage Sys. v. Train, 539 F.2d 1006, 1009 (4th Gir. 1976) ("[T]he Federal Water Pollution Control Act was designed to enlist the aid of the states . . . ."). But $c f$. Silkwood v. Kerr-McGee Corp., 104 S. Ct. 615, 633 (1984) (Blackmun, J., dissenting) (Congress intended to prohibit a state court from enjoining the operation of a nuclear power plant on the ground that it is unsafe.); Pacific Gas \& Elec. Co. v. State Energy Resources Conservation \& Dev. Comm'n, 461 U.S. 190, 212-13 (1983) (Congress has occupied the entire field of regulating nuclear radiation hazards.).

${ }^{377}$ This statement is valid at least where the standards merely set a maximum level of pollutant emissions, rather than specifying the manner in which those emission limitations are to be achieved. If the federal and state regulations required the installa- 
to federal standards and pay damages to those injured by the pollution. ${ }^{378}$ In addition, the availability of state common-law remedies for intrastate harms does not pose an obstacle to the full accomplishment of congressional objectives, since Congress has encouraged the states to exceed minimum federal standards. ${ }^{379}$ In fact, by supplementing the effluent limitations promulgated under the federal statutes with state common-law remedies, the state courts would further the statutory goals of restoring or maintaining the integrity of the nation's environment. ${ }^{380}$

tion of two different types of pollution control equipment, then a conflict could arise. With certain limited exceptions, the Clean Air and Water Acts specify only the level of emissions permitted, and do not require the installation of particular control technologies to achieve those emission reductions.

${ }^{\text {s78 }}$ See Ferebee v. Chevron Chem. Co., 736 F.2d 1529, 1541 (D.C. Cir.) ("Chevron can comply with both federal and state law by continuing to use the EPA-approved label [under EPA regulations issued pursuant to the Federal Insecticide, Fungicide, and Rodenticide Act [FIFRA], 7 U.S.C. $\$ \S 136-136 y$ (1982)] and by simultaneously paying damages to successful tort plaintiffs . . . ."), cert. denied, 105 S. Ct. 545 (1984); Ouellette v. International Paper Co., 602 F. Supp. 264, 271 (D. Vt. 1985) ("[T]he discharger remains free to operate [under a NPDES permit] so long as it pays for the injury it causes.").

${ }^{379}$ See supra notes 370-73 and accompanying text; Chevron U.S.A., Inc. v. Hammond, 726 F.2d 483, 489 (9th Cir. 1984) (Congress sought to encourage a federal-state partnership for the control of water pollution.), cert. denied, 105 S. Ct. 2686 (1985); see also Ferebee v. Chevron Chem. Co., 736 F.2d 1529, 1541 (D.C. Cir.) (The federal statute governing the use of pesticides permits state imposition of more stringent constraints on pesticide use than those imposed by the EPA.), cert. denied, 105 S. Ct. 545 (1984).

In certain limited situations, the specific application of state common-law standards that are more stringent than the federal standards may conflict with the accomplishment of congressional objectives. Congress may decide, for example, that the federally specified level of emission control represents the maximum that a particular industry is economically capable of achieving and that the industry should not be burdened by more stringent controls. In such a situation, the application of state commonlaw standards more stringent than the federal controls might frustrate congressional objectives by threatening the viability of the defendant discharger. Where Congress has decided to specify a maximum level of emission control, however, it has barred explicitly the application of more stringent state standards. See, e.g., 33 U.S.C. $§ 1322(\mathfrak{f})(1)$ (1982) (barring states from adopting controls on the use of marine sanitation devices on vessels); 42 U.S.C. $\S 7543$ (barring states from adopting or enforcing standards relating to the control of emissions from new motor vehicles or motor vehicle engines); $i d$. $\S 7545$ (c)(4) (prohibiting states from prescribing controls on the use of fuels or fuel additives in motor vehicles or motor vehicle engines); $i d$. $\$ 7573$ (prohibiting states from adopting or enforcing emission standards for aircraft or aircraft engines unless those standards are identical to federal standards). In light of these express prohibitions on state formulation of emission controls in certain areas, the courts should be reluctant to infer conflicts between the accomplishment of congressional objectives and the application of state common-law standards not explicitly prohibited by the statutes.

s80 See Ouellette v. International Paper Co., 602 F. Supp. 264, 271 (D. Vt. 1985) (citing S. REP. No. 414, 92d Cong., 2d Sess. 81 (1971), reprinted in 1972 U.S. CoDE ConG. \& AD. News 3668, 3678); see also 33 U.S.C. § 1251(a) (purpose of Clean Water Act is restoration and maintenance of the "integrity of the Nation's Waters."); 42 U.S.C. $\S 7401$ (b)(1) (purpose of Clean Air Act is protection of the quality of national air resources); $i d$. $\S 7470$ (purpose of preventing significant deterioration of 
The conclusion that state common-law compensatory remedies for intrastate injuries do not conflict with the federal statutes is reinforced by the courts' reluctance to preempt state tort liability. "The provision of tort remedies to compensate for personal injuries is a subject matter of the kind [the Supreme] Court has traditionally regarded as properly within the scope of state superintendence." "\$81 The courts will not find federal preemption of such traditional state concerns absent a " clear and manifest" " demonstration of congressional intent to preempt. ${ }^{382}$ The Supreme Court, for example, recently refused to find that state common-law punitive damage awards for exposure to radioactive substances were preempted in the absence of "an irreconcilable conflict between the federal and state standards." Kerr-McGee Corp. ${ }^{384}$ was especially reluctant to find preemption of state common-law damage remedies because no such federal remedies existed for persons injured by exposure to radioactive materials. ${ }^{985}$ Fol-

Clean Air Act standards is protection of public from effects of pollution); Hazardous and Solid Waste Amendments of 1984, Pub. L. No. 98-616, § 101(b), 98 Stat. 3221, 3224 (national policy is expeditious reduction of hazardous waste).

s81 Ferebee v. Chevron Chem. Co., 736 F.2d 1529, 1542 (D.C. Cir.) (quoting Florida Lime \& Avocado Growers, Inc. v. Paul, 373 U.S. 132, 144 (1963)), cert. denied, 105 S. Ct. 545 (1984); see also Jackson v. Johns-Manville Sales Corp., 750 F.2d 1314,1325 (5th Cir. 1985) ("Ensuring the availability of compensation for injured plaintiffs is predominantly a matter of state concern . . . ."); Ginn v. Consolidation Coal Co., 107 Ill. App. 3d 564, 566, 437 N.E.2d 793, 795 (1982) ("Tort liability is traditionally a function of state common law . . . .") (citing United Constr. Workers v. Laburnum Constr. Corp., 347 U.S. 656, 663-64 (1954)).

${ }^{382}$ Ferebee v. Chevron Chem. Co., 736 F.2d 1529, 1542 (D.C. Cir.) (quoting Rice v. Santa Fe Elevator Corp., 331 U.S. 218, 230 (1947)), cert. denied, 105 S. Ct. 545 (1984); see also Ouellette v. International Paper Co., 602 F. Supp. 264, 269 (D. Vt. 1985) (refusing to find preemption without demonstration of congressional intent).

sss Silkwood v. Kerr-McGee Corp., 104 S. Ct. 615, 626 (1984). An award of punitive damages can be viewed as regulatory rather than compensatory in nature. See id. at 628-30 (Blackmun, J., dissenting). Viewed in this light, the Silkwood decision reflects the Court's reluctance to preempt state common-law regulatory as well as compensatory relief in areas of traditional state concern.

s84 104 S. Ct. 615 (1984).

s88 See id. at 623 ("It is difficult to believe that Congress would, without comment, remove all means of judicial recourse for those injured by illegal conduct."); $i d$. at $629 \mathrm{n} .7$ ("It is inconceivable that Congress intended to leave victims with no remedy at all . . . The absence of federal regulation governing the compensation of victims of nuclear accidents is strong evidence that Congress intended the matter to be left to the State."); see also Ouellette v. International Paper Co., 602 F. Supp. 264, 269 (D. Vt. 1985) (holding that Congress did not intend to preempt state common-law compensatory remedies for interstate water pollution when it enacted the Clean Water Act); Chappell v. SCA Serv., Inc., 540 F. Supp. 1088, 1100 (C.D. Ill. 1982) (holding that the Toxic Substances Control Act, 15 U.S.C. $\$ \S 2601-2629$ (1982), does not preempt state common-law nuisance actions for damages, in part because such actions "may be the only way plaintiffs can recover any damages which may have accrued to them"); $c f$. Comment, supra note 90, at 394-95 (In cases of interstate pollution, the case for the preservation of common-law damage remedies is stronger than that for injunctive 
lowing the Court's decisions in Milwaukee II and National Sea Clammers, no federal damage remedy appears to be available for injuries caused by air or water pollution, ${ }^{386}$ and thus, it seems likely that the Court would refuse to preempt state common law.

A consideration of the four values affected by Congress's choice of private remedies lends more support for the position that Congress did not intend to preempt state common-law remedies to redress intrastate harms. Two of these values, individual liberty and efficiency, support the preservation of state common-law remedies. In addition, the conclusion that the Clean Air and Water Acts do not preempt these remedies may promote legitimacy.

In one respect the preemption of state common-law remedies appears consistent with the Milwaukee II Court's desire to promote legitimacy. In Milwaukee II the Court deemed the invocation of federal common-law remedies in the area of water pollution control "peculiarly inappropriate" in light of the arcane and technically complex nature of the subject matter. ${ }^{387}$ Presumably state judges have no greater scientific and technological expertise in pollution control matters than federal judges. Accordingly, confining the authority to formulate standards of conduct to the expert administrative agency, the EPA, may promote the legitimacy of the pollution control program. The judiciary's role would be limited to determining whether the agency's standard is consistent with the statute and whether, as a factual matter, a particular polluter has violated the standards adopted by the agency. This argument is less than compelling, however, since for centuries state and English common-law courts have resolved complex pollution controversies by adopting their own common-law standards in nuisance, trespass, and other cases. Moreover, the Milwaukee II majority's denigration of the capacity of the judiciary to resolve pollution control controversies is difficult

relief.).

${ }^{386}$ Unless Congress amends the current statutes, no federal damage remedy is available, except perhaps if the courts find that the federal statutes do not preempt a particular area of federal common law-for example, injury caused by acid rain pollution-and that damage remedies are available to private plaintiffs in a federal commonlaw cause of action. See supra notes 198, 269-74 and accompanying text.

Many courts, both state and federal, in opinions issued after the Milwaukee II decision, have permitted private or governmental litigants in pollution cases to proceed under state common-law tort theories, without explicitly addressing the preemption issue. See, e.g., United States v. Hooker Chem. Plastics Corp., 607 F. Supp. 1052, 1055 n.3 (W.D.N.Y. 1985); United States v. Allied Chem. Corp., 587 F. Supp. 1205, 120809 (N.D. Cal. 1984); Philadelphia Elec. Co. v. Hercules, Inc., 587 F. Supp. 144, 154 (E.D. Pa. 1984); Carriker Ford, Inc. v. Clow Corp., 21 Env't Rep. Cas. (BNA) 1419 , 1422 (S.D. Iowa 1984); Birchwood Lakes Colony Club, Inc. v. Borough of Medford Lakes, 90 N.J. 582, 591-96, 449 A.2d 472, $477-79$ (1982).

${ }^{387}$ See 451 U.S. at 325 . 
to take at face value in light of the Court's subsequent decision in Weinberger $v$. Romero-Barcelo. ${ }^{388}$

Legitimacy may be promoted by confining the ability to adopt pollution control standards to the legislative branch, which presumably represents the views of the electorate, and the administrative agencies, which are subject to legislative oversight. Professors Stewart and Sunstein contend, however, that "the link between electoral representation and administrative decision is too weak" to support such a contention, thereby "undermin[ing] the claim that judicial creation of additional remedies would circumvent political controls on administration. Indeed, such remedies may help promote agency fidelity to statutory purposes." ${ }^{\text {389 }}$ Moreover, the availability of state common-law remedies increases public participation in the process of regulating pollution. This ability to participate may heighten the perception that important social and economic decisions are being made through open and democratic processes. $^{390}$

The extent to which the preservation of state common-law remedies for intrastate harms promotes individual liberty is far less equivocal. Supplemental state common-law remedies foster individual liberty in at least three ways. First, the availability of judicial remedies to protect persons or property harmed by polluters acting in compliance with

388456 U.S. 306 (1982). For a discussion of the Court's willingness to allow judges to exercise their discretion in this area, see supra text accompanying notes $99-$ 100. The preemption of state common law, however, may promote legitimacy by providing greater certainty and consistency of obligations on the part of dischargers. See Zerbe, Optimal Environmental Jurisdictions, 4 Ecology L.Q. 193, 211 (1974). One court, however, concluded that Congress did not intend that the issuance of a NPDES permit under the Clean Water Act would

confer an absolute right to discharge to the extent allowed by the permit. Since compliance with the Act does not constitute a defense to a common law action for damages, Congress must have recognized that some uncertainty would result to dischargers of pollutants. The goal of the [Clean Water Act] is not finality; rather, it is the elimination of the discharge of pollutants.

Ouellette v. International Paper Co., 602 F. Supp. 264, 271 (D. Vt. 1985) (citations omitted).

s89 Stewart \& Sunstein, supra note 66, at 1200.

soo See id. Professor Michelman contends that the availability of supplemental common-law remedies against polluters complying with a centralized regulatory system of controls may serve at least three other functions. First, private suits might be justified by their ability to "backstop[ ] or fill[ ] in" the regulatory system's deterrent purposes. Michelman, supra note 41, at 676 . Second, supplemental common-law remedies may serve a "guidance function, bringing to our attention that the collective controls are generally weaker than they 'ought' to be." Id. at 676-77. Third, common-law remedies might "substitute for derelict officialdom in the enforcement of collective standards." Id. at 678 . These three functions appear to enhance the legitimacy of the statutory program for controlling pollution. 
the federal statutes serves "an important separation-of-powers function that is not automatically displaced by-the legislature's creation of administrative agencies." ${ }^{301}$ Second, the retention of state authority to adopt pollution standards more stringent than federal controls promotes non-centralized decisionmaking and state self-governance concerning important social and economic choices. ${ }^{392}$ The Supreme Court reaffirmed in Milwaukee II that its preemption analysis "has included 'due regard for . . . the principle of diffusion of power . . . as a promoter of democracy." "393 Third, preserving state common-law remedies enhances individuals' ability, with governmental assistance, to protect against intrusions upon their health, safety, and property by other private entities. Indeed, the preservation of these remedies may even be mandated by the due process clause's guarantees against governmental deprivation of liberty and property. ${ }^{304}$

Finally, preserving supplemental state common-law remedies may foster economic efficiency. A state court award of compensatory damages may promote efficiency by forcing the discharger to internalize the costs it imposes on others. ${ }^{395}$ Those internalized costs will then be reflected in the prices of the discharger's products, sending consumers a more accurate signal of the costs of the discharger's operations. Since consumers will be confronted with the opportunity costs of devoting society's resources to the production of the discharger's products, they will be able to make purchasing decisions that accurately reflect their value preferences. The resulting forces of supply and demand will maximize the value of production, as measured by consumers' willingness to pay for the various products at their disposal. ${ }^{398}$

s91 Stewart \& Sunstein, supra note 66, at 1199. "In an administrative era, courts should generally assume, unless the legislature provides otherwise, that they may continue to serve that function by protecting private interests through the creation of remedies for deficient agency performance." Id. at 1119-20.

392 See Sunstein, supra note 66, at 422 (arguing that federal statutes should not lightly be interpreted to extinguish state common-law remedies because of their importance to a state's ability to protect its own citizens from injury).

393451 U.S. at 316 (quoting San Diego Bldg. Trades Council v. Garmon, 359 U.S. 236,243 (1959)).

sos See supra notes 329-48 and accompanying text. Some writers have contended that the common-law system creates rules of entitlement to the protection of bodily integrity and private property. See, e.g., Furrow, supra note 109, at 1429; Stewart \& Sunstein, supra note 66, at 1233.

395 See Stewart \& Sunstein, supra note 66, at 1297. See generally Note, The CostInternalization Case for Class Actions, 21 STAN. L. REv. 383 (1969). An award of injunctive relief, on the other hand, may lead to an inefficient result if the costs of complying with the injunction exceed the benefits of such compliance. See Michelman, supra note 41, at 667-68 (In a particular case, the polluter may not be the cheapest cost avoider.).

396 See Michelman, supra note 41, at 676 (A mixed regulatory and common-law 
The preservation of state common-law remedies raises the possibility of a conflict between federal and state interests. The fourth value, accommodation, may be served by preempting state law and insuring the application of uniform federal standards. ${ }^{397}$ The instances in which federal-state conflicts will develop, however, will be rare. ${ }^{398}$ For the most part, Congress has decided not to insist on federal uniformity of pollution control, but rather to permit the states to adopt their own, more stringent standards. ${ }^{389}$

\section{Preemption for Interstate Purposes}

The preemption issue is more difficult to resolve where the polluter and the person injured by its discharges are located in two different states. A court would be justified in finding that common-law remedies have been preempted if Congress has occupied the field of interstate pollution control ${ }^{400}$ or if the application of state remedies would conflict with the achievement of federal objectives. The factor that distinguishes the application of state common-law remedies in an interstate dispute from its use in an intrastate suit is the attempt by one state to apply its law to a polluter located in another state. This attempt may impair the legitimacy of pollution control efforts by creating the possibility of discriminatory applications of the forum state's law to out-of-state polluters. It may also undercut individual liberty by infringing upon the sovereignty of the state where the polluter is located, and it may provoke interstate disputes and, therefore, be inconsistent with the accommodation value. This section explores whether any of these difficulties justify the conclusion that Congress intended to preempt the application of state common-law remedies to interstate pollution disputes.

system for controlling pollution, even though it may impose "double-payments" on some polluters, "might lead to less misallocation than entirely foregoing the nuisance judgment's capacity to bring special local costs to bear on [the] cheapest avoiders.").

${ }^{307}$ Cf. Milwaukee II, 451 U.S. at 333 n.2 (Blackmun, J., dissenting) ("In deciding whether federal law pre-empts state law, the Court must be sensitive to the potential frustration of national purposes if the States are permitted to control conduct that is the subject of federal regulation.").

398 See supra note 379.

s89 See supra notes $370-73$ and accompanying text.

100 For a discussion of the various means by which the federal and state governments attempt to deal with interstate environmental problems, see generally Lutz, Interstate Environmental Law: Federalism Bordering on Neglect?, 13 S.W.U.L. REv. 571 (1983). 


\section{The Nature of the Dispute}

In analyzing the preemption issue, a hypothetical example of an interstate pollution dispute will be employed to explore whether applying state common-law remedies in the interstate context is consistent with the values of legitimacy, individual liberty, and accommodation. ${ }^{401}$ Suppose that company $A$, located in state $A$, discharges effluents into a river, which carries the effluents into state $B$. The company's discharges are in full compliance not only with federally issued effluent limitations under the Clean Water Act, but also with state $A$ 's pollution control standards. A citizen in state $B$ brings suit against the company in state $B$, alleging that the company's discharges create a nuisance and impose substantial harm on the state $B$ citizen. After comparing the utility of the defendant's conduct with the gravity of the harm to the plaintiff, ${ }^{\mathbf{4 0 2}}$ the state $B$ court rules in favor of the plaintiff and requires the company to reduce its discharges to the extent necessary to avoid further harm. Assuming that compliance with the court decree will require the company either to spend more to install additional pollution control equipment or to reduce the scope of its operations, the company's profitability will be reduced. ${ }^{403}$

\section{Discovery of Congressional Intent}

\section{a. Explicit Preemption}

The plaintiff in the preceding hypothetical lawsuit will be barred from resorting to state $B$ 's common-law remedies only if Congress intended to preempt these remedies when it enacted the federal water pollution control legislation. ${ }^{404}$ That intent can be manifested expressly

401 The economic efficiency of applying state common-law remedies should be the same whether the dispute is intrastate or interstate. Thus, the application of state common-law remedies in the interstate context arguably promotes economic efficiency. See supra notes 395-96 and accompanying text.

${ }^{402}$ Courts in nuisance cases often engage in such a balancing of factors to determine whether an actionable nuisance exists. See RESTATEMENT (SECOND) OF TORTS § 826 (1979).

108 For a comparable fact situation, see State v. Champion Int'l Corp., 22 Env't Rep. Cas. (BNA) 1338 (Tenn. Ct. App. 1985); see also Ouellette v. International Paper Co., 602 F. Supp. 264 (D. Vt. 1985) (Under the Clean Water Act savings clause and state authority provisions, Vermont landowners could sue a New York polluter for damages under the common law of Vermont, the state where the pollution-caused injury occurred.).

${ }^{404}$ The court in Ouellette v. International Paper Co., 602 F. Supp. 264 (D. Vt. 1985), stated that Milwaukee $I$ and $I I$ "stand for the proposition that attempts by one state to halt discharge into interstate waters emanating from another state implicate uniquely federal concerns." Id. at 268. According to the court, the issue, therefore, is not whether federal legislation has preempted state law, since federal law has always 
or implicitly in the design of the statutory program or in its legislative history. Congress did not preempt state common-law remedies for interstate harms by expressly occupying the field of interstate pollution through the enactment of the Glean Air and Water Acts. The savings clauses of the citizen suit provisions of these two Acts deny any intent to restrict a person's right to seek relief "under any . . . common law." $40 s$ These clauses draw no distinction between interstate and intrastate disputes in describing the right to seek common-law relief. Similarly, the federal statutes do not distinguish in-state sources from outof-state sources in the provisions permitting states to adopt or enforce pollution control standards more stringent than the federal requirements. ${ }^{408}$

governed interstate water pollution disputes; "[r]ather, the controlling question is the extent to which Congress authorized, either expressly or implicitly, resort to state common law in a situation such as this." Id.

Whether the issue is framed in terms of congressional preemption or authorization, the analysis will involve an inquiry into legislative intent, as reflected in the statutory language and legislative history. A court may be more reluctant to conclude that state law applies under a congressional authorization analysis than under a preemption analysis, since under the former analysis, the traditional "presumption" against displacing state law may not apply. See supra notes 349-52 and accompanying text. The court in Ouellette had little difficulty concluding, however, that Congress intended to authorize the use of the common law of the state in which injury occurs in an interstate pollution dispute. See 602 F. Supp. at 266-72.

40533 U.S.C. § 1365(e) (Clean Water Act); 42 U.S.C. § 7604(e) (Clean Air Act); see also Ouellette v. International Paper Co., 602 F. Supp. 264, 270 (D. Vt. 1985) ("It . . . seems inescapable that Congress, by passage of the [Clean Water Act's] saving clause [33 U.S.C. $\S 1365(\mathrm{e})]$ and state authority provisions [id. $\S 1370(2)]$, intended to preserve" state common-law actions for interstate pollution in the state where injury occurs); State v. Champion Int'l Corp., 22 Env't Rep. Cas. (BNA) 1338, 1342 (Tenn. Ct. App. 1985) ("Section 1365(e) [of the Clean Water Act] is clear" and preserves state common-law remedies in interstate disputes). But see Illinois v. City of Milwaukee, 731 F.2d 403 (7th Cir. 1984), cert. denied, 105 S. Ct. 979 (1985), in which the court interpreted section 505(e) of the Clean Water Act, 33 U.S.C. $\S 1365(e)$, to exclude the preservation of state common-law remedies for interstate harms: "[I]t seems implausible that Congress meant to preserve or confer any right of the state claiming injury (State II) or its citizens to seek enforcement of limitations on discharges in State I by applying the statutes or common law of State II." Id. at 414 (emphasis added).

${ }^{108}$ See 33 U.S.C. $§ 1370$ (Glean Water Act); 42 U.S.C. $§ 7416$ (Glean Air Act). But see Illinois v. Gity of Milwaukee, 731 F.2d 403, 413 (7th Gir. 1984) (interpreting section 510 of the Clean Water Act, 33 U.S.C. $\$ 1370$, to refer "to the right of a state with respect to discharges within that state, and not to any right of a state to impose more stringent limitations upon discharges in another state"), cert. denied, $105 \mathrm{~S}$. Ct. 979 (1985). The two courts that have disagreed with the Seventh Circuit's decision relied on section 510(2) of the Glean Water Act, 33 U.S.C. $§ 1370(2)$, to reach the contrary result. This subsection states that nothing in the Act shall "be construed as impairing or in any manner affecting any right or jurisdiction of the States with respect to the waters (including boundary waters) of such States." See Ouellette v. International Paper Co., 602 F. Supp. 264, 267-70 (D. Vt. 1985); State v. Champion Int'l Corp., 22 Env't Rep. Cas. (BNA) 1338, 1342 (Tenn. Ct. App. 1985). 
The application of state $B$ 's common-law remedies to a state $A$ polluter would not actually conflict with federal law in the sense that it would be physically impossible to comply with both sets of standards. By complying with the most stringent requirement-either federal or state-company $A$ also complies with the more lenient controls. ${ }^{407}$

\section{b. Implicit Preemption}

If Congress wished to preempt state common-law remedies for interstate harms, it could do so implicitly. Implicit occupation of the field of interstate pollution control could be based on the creation of a pervasive scheme of federal regulation, the need for federal uniformity, or the need to insure the achievement of dominant federal interests or objectives. ${ }^{408}$ Similarly, an implicit conflict between state and federal law would arise if the application of state common-law remedies to out-ofstate sources presented an obstacle to the accomplishment of federal objectives. ${ }^{409}$

\section{(i) Pervasive Federal Regulation}

Consider again a source located in one state, such as company $A$ in our hypothetical example, whose emissions cause injury in another state, state $B$. The federal statutes do not regulate company $A$ so pervasively that the application of supplemental state $B$ common law has been implicitly precluded. ${ }^{410}$ The Glean Water Act provides no more extensive federal control mechanisms in the interstate discharge context than it does with respect to discharges whose effects are confined to one state. Indeed, the Act has been criticized on the ground that its interstate discharge control mechanisms are virtually nonexistent, ${ }^{411}$ at least

407 See supra notes $377-78$ and accompanying text. If state $B$ 's courts assess damages against company $A$, even though the company is in full compliance with federal standards, the company can comply with both federal and state $B$ 's laws by limiting discharges in accordance with the federal standards and compensating, in accordance with the state $B$ court decree, those injured by the discharges. See Ouellette v. International Paper Co., 602 F. Supp. 264, 271 (D. Vt. 1985).

${ }^{408}$ See supra notes 354-56 and accompanying text.

409 See supra text accompanying notes 358-60.

410 The federal air and water pollution control statutes expressly permit the application of more stringent state standards to dischargers, reflecting Congress's desire to implement a federal-state partnership in the control of pollution. See supra notes 37275 and accompanying text. The authority to impose more stringent state controls is not expressly limited to dischargers that are located in the state imposing the controls. See Ouellette v. International Paper Co., 602 F. Supp. 264, 269 (D. Vt. 1985); see also supra text accompanying notes 405-06 (noting that the language of the Clean Air and Water Acts concerning more stringent state standards draws no distinction between instate and out-of-state polluters).

411 For a comprehensive explanation of the gaps and shortcomings of the Clean 
where a state with controls more stringent than the minimum federal requirements tries to enforce those controls against an out-of-state source. ${ }^{42}$ While the Clean Air Act does have several techniques for handling interstate pollution problems, ${ }^{413}$ these cumbersome mechanisms hardly provide a "pervasive" and comprehensive means of resolving these problems, ${ }^{\mathbf{4 1 4}}$ especially in the area of long-range transport and acid deposition. ${ }^{416}$ The EPA has taken the position that the Act's procedures for resolving interstate pollution disputes do not even apply to sulfates, a principal form of acid precipitation, because no national am-

Water Act in the interstate context, see generally Comment, supra note 90 (contending that because the Act focuses on the behavior of dischargers rather than the cleanup of a water body itself, nuisances that endanger the health and welfare of citizens may occur even when dischargers comply with federal regulatory requirements; a state is free to adopt more stringent state emissions controls, but the Act provides no forum for enforcing those controls against a source located in another state). See also Stewart, Interstate Resource Conflicts: The Role of Federal Courts, 6 HARv. ENvTL. L. Rev. 241, 26061 (1982) (The Clean Water Act is unlikely to meet the receiving state's concerns because minimum nationally uniform levels of pollution control do not ensure adequate water quality in the receiving state. "Moreover, the Environmental Protection Agency, like other federal agencies, is reluctant to take on heated interstate controversies.") (footnote omitted).

${ }^{412}$ Although the plain language of the statute appears to authorize the receiving state to impose more stringent controls on out-of-state dischargers, at least one court has concluded that the receiving state may not do so. See Illinois v. City of Milwaukee, 731 F.2d 403, 410-11, 413 (7th Cir. 1984) ("[E]quitable reconciliation of competing uses of an interstate body of water" precluded Illinois from imposing its more stringent discharge limitations on out-of-state sources.), cert. denied, 105 S. Ct. 979 (1985). But see Ouellette v. International Paper Co., 602 F. Supp. 264, 272 (D. Vt. 1985) (The passage of the 1972 amendments to the Clean Water Act indicates Congress's view that pollution is no longer a legitimate competing use of water resources.); State v. Champion Int'l Corp., 22 Env't Rep. Cas. (BNA) 1338, 1342 (Tenn. Ct. App. 1985) (The savings clause of the Clean Water Act's citizen suit provision, 33 U.S.C. $\S 1365(\mathrm{e})$, by preserving "any right . . u under any statute or common law," invites states to adopt more stringent water quality standards than those set by the federal government.).

${ }^{413}$ See 42 U.S.C. $\$ \S 7410($ a)(2)(E), 7426.

$\$ 14$ To date no state has successfully invoked the section 126 petition procedure to abate pollution generated in another state. But cf. New York v. Thomas, 613 F. Supp. 1472 (D.D.C. 1985) (compelling the EPA to require several midwestern states to revise their state implementation plans (SIP's) pursuant to section 115 of the Clean Air Act, 42 U.S.C. \& 7415, to eliminate danger to Canadian health or welfare caused by acid deposition originating from midwestern emission sources).

416 See, e.g., F. ANDERson, D. MANDELkER \& A. TARLOck, supra note 60, at 310 (The problem of interstate pollution "severely . . . tests" the Clean Air Act, yet that problem is "minor compared with the problem of controlling acid precipitation and deposition."); see also Ostrov, Interboundary Stationary Source Pollution-Clean Air Act Section 126 and Beyond, 8 Colum. J. ENvTL. L. 37, 80-93 (1982) (arguing that the Clean Air Act does not deal adequately with transboundary pollution, and suggesting a two-pronged approach to the problem with stronger administrative control and tougher legislative standards); Comment, Jefferson County's Lament: Clean Air Act Offers No Relief for Interstate Pollution, 14 ENVTL. L. REP. 10,298 (1984) (The EPA, using only air quality modeling of dubious accuracy and ignoring interstate inequities, refused to tighten the sulfur dioxide control requirement on an Indiana power plant polluting the air of a Kentucky county.); Note, supra note 198, at 158-78. 
bient air quality standard has been enacted for that pollutant. ${ }^{416} \mathrm{~A}$ finding of implicit federal preemption of state common-law remedies, therefore, must be based on something other than the pervasive nature of the federal statutory programs for controlling interstate pollution.

(ii) The Need for Uniformity and the Protection of Dominant Federal Interests

Implicit occupation of the field of interstate pollution could be based on a congressional determination that a uniform set of pollution controls, enacted at the federal level, is necessary in the interstate pollution context. On remand from the Supreme Court's decision in Milwaukee II, the Court of Appeals for the Seventh Circuit held in Illinois $v$. City of Milwaukee (Milwaukee III) ${ }^{417}$ that Illinois could not seek injunctive relief against out-of-state dischargers under Illinois state common law. The court characterized the pollution of interstate waters as "a problem of uniquely federal dimensions requiring the application of uniform federal standards." 418

The fact that interstate pollution disputes "implicate uniquely federal concerns," however, does not necessarily reflect a congressional determination that a uniform level of environmental quality, in and of itself, is necessary. ${ }^{\mathbf{4 1 0}}$ Both the Clean Air Act and the Glean Water Act expressly authorize the states to develop and apply their own emission limitations, provided those limitations are at least as stringent as the federal controls. ${ }^{420}$ The only uniformity required by the statutes is adherence to the minimum federal standards found necessary by Congress and the EPA to protect health and the environment. ${ }^{421}$ Nor do the statutes mandate that all fifty states strike a uniform balance between the goal of environmental protection and the desire to avoid unduly stifling economic growth and productivity. Because the states can apply more stringent emission limitations, at least on sources located within their own boundaries, they can impose greater economic burdens on selected industries, many of which will be engaged in interstate commerce, than

$\$ 16$ See supra text accompanying note 271.

417731 F.2d 403 (7th Cir. 1984), cert. denied, 105 S. Ct. 979 (1985).

118 Id. at 410; see also Committee for the Jones Falls Sewage Sys. v. Train, 539 F.2d 1006, 1014 (4th Cir. 1976) (Butzner, J., dissenting) (Shuffling between federal and state courts "would provoke diversity, rather than achieve uniformity, in the law governing the abatement of nuisances in the navigable waters of the United States."); cf. Chevron U.S.A., Inc. v. Hammond, 726 F.2d 483, 492 n.12 (9th Cir. 1984) ("[A]s to environmental regulation of deep ocean waters, the federal interest in uniformity is paramount."), cert. denied, 105 S. Ct. 2686 (1985).

419 See Ouellette v. International Paper Co., 602 F. Supp. 264, 268 (D. Vt. 1985).

120 See supra notes 370-71, 375-76 and accompanying text.

421 See Bleiweiss, supra note 274 , at 61 . 
the federal standards alone impose. ${ }^{422}$

A factor unique to the interstate pollution dispute, however, could form the basis for a legislative determination that the states should be precluded from resorting to standards that differ from those promulgated by the EPA under the Clean Air and Water Acts in resolving an interstate pollution dispute. Invoking state common-law remedies to resolve an interstate pollution dispute may involve a state's application of its own laws to residents of another state. This extraterritorial application of the forum state's common law might be viewed as a threat to the values of legitimacy, individual liberty, and accommodation, which this Article has described as either congressional objectives underlying the federal pollution control statutes or values derived from the Constitution.

The potential problems created by the use of state common law to resolve an interstate pollution dispute are illustrated by the water pollution example set forth above. If the injured state $B$ plaintiffs bring suit in a state $B$ court, and seek to invoke state $B$ common law, there is a danger that the state $B$ court will discriminate, or at least be perceived by the state $A$ defendant as discriminating, against the out-ofstate defendant. The court in state $B$ may be more concerned with protecting the health and property of state $B$ residents than with safeguarding the vitality of state $A$ 's industries. State $B$ residents, moreover, may not be directly affected by the reduced profitability of a state $A$ company. The state $B$ court, therefore, may be more inclined to rule in favor of the plaintiffs and impose harsh remedies on the defendant than it would be if the polluter were also a state $B$ resident. Since nuisance cases are fact-specific and involve a rather amorphous balancing of the interests of the plaintiff, the defendant, and society as a whole, ${ }^{\mathbf{4 2 3}}$ it would be difficult to prove that the court is affording less favorable treatment to out-of-state polluters than it is to state $B$ companies that injure state $B$ residents, even if it were in fact true. Nevertheless, the mere perception of discriminatory application of state $B$ 's laws may detract from the legitimacy of a system that permits state $B$ plaintiffs to invoke common-law remedies to control the harms generated by company $A$ 's activities. ${ }^{424}$

122 Cf. Ferebee v. Chevron Chem. Co., 736 F.2d 1529, 1542 (D.C. Cir.) (permitting state compensatory actions because Congress intended to allow states to strike the balance between the costs and benefits of pollution regulation differently than Congress did), cert. denied, 105 S. Ct. 545 (1984).

123 See supra note 402 and accompanying text.

124 See Bleiweiss, supra note 274 , at $45 \mathrm{n} .36,60$; Stafford, supra note 260 , at 10,104 . An analogous problem could result if the injured state $B$ plaintiffs sued in a state $A$ court, invoking state $A$ 's common law. The state $A$ court may treat, or be 
The possibility of discrimination, and the decline in certainty generated by the supplementation of federal statutory standards with state common-law remedies, ${ }^{\mathbf{4 2 5}}$ arguably support the preemption of state law. Although preemption of common-law remedies eliminates one forum for public participation, ${ }^{426}$ this threat to legitimacy may be outweighed by the impairment to legitimacy caused by a system perceived as unfair. Regardless of the merits of this argument as a matter of policy, however, preemption remains a matter of congressional intent. The Court of Appeals in Milwaukee III, which held that the enactment of the Clean Water Act has preempted state common-law remedies in an interstate pollution dispute, pointed to no evidence in the legislative history that Congress considered, much less found persuasive, the possibility of discrimination against out-of-state parties. ${ }^{\mathbf{4 2 7}}$

The argument that Congress implicitly intended to preempt state common-law remedies would be strengthened if the failure to preempt would threaten not only legitimacy, but also individual liberty and accommodation. ${ }^{428}$ One of the components of the value of individual liberty described in this Article is the protection of each state's sovereignty. Intruding upon the integrity of a state's sovereignty may threaten the ability of the individual to participate in the development of local social, economic, and other policy choices. ${ }^{429}$ The court in Milwaukee III concluded that the attempt by Illinois-which allegedly suffered injury from pollution generated in Wisconsin-to impose its common law on a Wisconsin polluter would impermissibly infringe upon

perceived as treating, the state $B$ plaintiffs less favorably than it would state $A$ residents who bring a nuisance action against a state $A$ polluter.

${ }^{425}$ See supra note 388; see also Milwaukee III, 731 F.2d at 414 (If state commonlaw remedies were available in interstate pollution disputes, "[i]t would be virtually impossible to predict the standard for a lawful discharge into an interstate body of water. Any permit issued under the [Clean Water] Act would be rendered meaningless."). But see Ouellette v. International Paper Co., 602 F. Supp. 264, 271 (D. Vt. 1985) (Congress subordinated finality to the goal of eliminating the discharge of pollutants).

428 See supra note 390 and accompanying text.

427 See Milwaukee III, 731 F.2d at 414 ("In our opinion Congress could not have intended" to permit the supplementation of federal standards with state common-law remedies.); cf. Ouellette v. International Paper Co., 602 F. Supp. 264, 269 (D. Vt. 1985) ("TT]here is simply nothing in the [Clean Water] Act which suggests that Congress intended to impose . . . limitations on the use of state law" in interstate pollution disputes).

${ }^{428}$ If the preservation of state common-law remedies would impair all three of these values, some of which have constitutional implications, with no or few countervailing advantages, it would be reasonable to conclude that Congress could not have intended to preserve state common-law remedies, even if the legislative history of the federal statute is totally uninformative.

129 See supra note 71 and accompanying text. 
the latter state's sovereignty. ${ }^{430}$ The court concluded that the controversy was one "of federal dimensions, implicating the conflicting rights of states and inappropriate for state law resolution." therefore, ruled that Congress must have intended to preempt state common law in interstate pollution controversies to prevent an affront to the interests of the state of the pollution's origin, ${ }^{432}$ even though the Act is silent on the issue.

The circuit court's analysis is valid, as far as it goes. ${ }^{\mathbf{4 3 3}}$ Returning to the hypothetical interstate water pollution controversy, the fact that state $B$ 's (judicially imposed) pollution control standards are more stringent than those of state $A$ reflects a different balancing of economic and social policy considerations on the parts of the two state governments. ${ }^{434}$ The imposition of state $B$ 's standards on a company located in state $A$ would disrupt the balance struck by state $A$. By imposing its own policy determinations on state $A$ with respect to the appropriate use of the common resource, the interstate river, state $B$ appears to be infringing upon state $A$ 's ability to make policy determinations free from the interference of other states. ${ }^{\mathbf{4 3 5}}$ The preemption of state common-law remedies would avoid such an intrusion upon the sovereignty of state $A$. Accordingly, federal occupation of the field of interstate pol-

430 See 731 F.2d at 414 . The court stated that Congress intended to preclude the application of Illinois common law to out-of-state dischargers because the competition for the use of an interstate body of water is a matter of "special federal concern and the subject of federal law." Id. at 410; $c f$. Milwaukee I, 406 U.S. at 105 ("The question of apportionment of interstate waters is a question of 'federal common law' upon which state statutes or decisions are not conclusive."). But $c f$. Ouellette v. International Paper Co., 602 F. Supp. 264, 271 (D. Vt. 1985) (When the interstate pollution dispute is between private parties, "[t] $[$ here is little or no possibility that [the] litigation will escalate into a conflict between different state entities.") (footnote omitted).

${ }^{431}$ Milwaukee III, 731 F.2d at 414; see also City of Evansville v. Kentucky Liquid Recycling, Inc., 604 F.2d 1008, 1018 n.30 (7th Gir. 1979) ("[T] he laws of one state cannot control the use of the [interstate] river by citizens of other states."), cert. denied, 444 U.S. 1025 (1980).

4 S2 See Milwaukee III, 731 F.2d at 414.

43s A federal district court in Vermont labeled the Milwaukee III decision "an admirable attempt to deal with the difficult issues concerning the role of state law in controlling the pollution of interstate waters." Ouellette v. International Paper Co., 602 F. Supp. 264, 268 (D. Vt. 1985). The court in Ouellette nevertheless found that its analysis of the statute and legislative history "inevitably" led to a conclusion contrary to that of the Seventh Circuit in Milwaukee III. See id. at 272.

134 State $A$ 's policymakers may not have considered the harm to state $B$ 's residents caused by the company's discharges in determining the appropriate level of effluent limitations, since that harm represents costs not imposed upon, and external to, state $A$ 's residents. Conversely, the court in state $B$ may be more concerned with protecting against the risk of harm to the health of state $B$ residents than it is with the economic burdens that stringent pollution control requirements will impose on state $A$ 's industries.

4ss See Note, supra note 192 , at 526-27. 
lution could be justified as a means of protecting basic interests of federalism.

The analysis in Milwaukee III, however, is incomplete. The result in that case protects the sovereign interests of the state from which the pollution emanates, state $A$, while at the same time infringing upon the sovereignty of the state of the injured party, state $B$. In such a case, the benefit to individual liberty provided by protecting the sovereignty of the state of the pollution's origin is cancelled by the infringement on state $B$ 's sovereignty. ${ }^{436}$ Indeed, the preemption of state $B$ 's more stringent common-law standards may result in a net loss of individual liberty in light of the Supreme Court's recognition of the fundamental importance to a state's sovereignty of its ability to protect its environment from externally imposed harm. ${ }^{437}$

The Supreme Court began the development of a federal environmental common law early in the twentieth century when it recognized a state's right to insist that its environment not be polluted "by the act of persons beyond its control."438 The Court was aware that the imposition by the receiving state of its own stringent emission controls on a source located outside the state could have adverse economic consequences. ${ }^{439}$ Nevertheless, the Court stated that " $[t]$ he possible disaster to those outside the State must be accepted as a consequence of [the receiving state's] standing upon her extreme rights." ${ }^{440}$ The Court also indicated that a federal forum must be made available to the receiving state so that it could enforce its rights without resorting to force. ${ }^{\mathbf{4 1 1}}$ If, therefore, the preemption of state common-law remedies leaves the injured state, state $B$, with no alternative means of adequately protecting itself against the improper impairment of its environment by an out-ofstate polluter, the preemption constitutes a serious and impermissible

438 Cf. Ouellette v. International Paper Co., 602 F. Supp. 264, 268 (D. Vt. 1985) (viewing interstate water pollution disputes as "a problem of equitable apportionment" involving "the competing and conflicting interests of states and their citizens for limited quantities of interstate water").

437 See supra notes 148-61 and accompanying text.

438 Georgia v. Tennessee Copper Co., 206 U.S. 230, 238 (1907).

489 The Court addressed the possibility that Georgia, the state seeking to enjoin extraterritorial emissions, might adversely affect its own citizens by a refusal to compromise with Tennessee, the state in which the emissions originated. See id. at 239. The Court was obviously also aware of the impact of an injunctive decree on the emissions source and the state in which it was located. See id. at 238 (discussing the "calamity of a possible stop to the defendants' business" and the "commercial possibility or impossibility" of reducing the copper company's sulfur dioxide emissions).

440 Id. at 239; see also Texas v. Pankey, 441 F.2d 236, 240 (10th Cir. 1971) (discussing the states" "quasi-sovereign ecological rights").

141 See Georgia v. Tennessee Copper Co., 206 U.S. at 237; see also Missouri v. Illinois, 180 U.S. 208, 241 (1901) (The federal government has a duty to provide a remedy for the receiving state.). 
infringement upon state $B$ 's sovereignty.

State $B$ has several potential alternative means for protecting itself. A federal regulatory forum for protecting state $B$ 's waters from impairment by company $A$ 's discharges is one possibility. State $B$ could participate in company $A$ 's permit proceedings in an attempt to persuade the EPA to impose effluent limitations sufficiently stringent to protect the health of state $B$ 's residents and its environment. ${ }^{42}$ State $B$ has a right to participate in the permit proceeding even if the permit-issuing authority is state $A$, rather than the EPA. ${ }^{43}$ The Court in Milwaukee II characterized these opportunities as "ample" ones to protect the receiving state's interests. ${ }^{444}$

Some have argued, however, that the Glean Water Act fails to protect state $B$ from outside emissions when it desires to exclude discharges at levels that are more stringent than those contained in the minimum federal requirements. ${ }^{445}$ The Act may fail to provide this protection even though company $A$ 's discharge of emissions (which is in compliance with federal requirements) causes injury to persons or resources in state $B .{ }^{448}$ The Clean Air Act's protections against outside emissions (including acid rain transported from stationary sources several states away) appear even less adequate, in part because the Act does not currently cover sulfate or nitrate deposition. ${ }^{477}$ The permit issuance process, therefore, fails to protect state $B$ 's "quasi-sovereign ecological rights. ${ }^{2448}$

Alternatively, state $B$, or injured state $B$ residents, can seek relief through the courts. State $B$ can initiate a citizen suit against company $A$ in federal district court. It is not clear, however, whether the citizen suit provisions encompass the enforcement against out-of-state sources of effluent limitations that are more stringent than those provided by federal requirements. ${ }^{449}$ If state $B$ is unable to use the citizen suit provisions to protect its citizens and resources, an injured state $B$ resident might seek compensation for harms caused by the company's discharges. But no right to damages exists under the federal statutes, and

442 See 33 U.S.C. § 1342(a)(3), (b)(5).

443 See id. § 1342(b)(5).

444 See 451 U.S. at 326.

445 See supra notes 410-12 and accompanying text. But see 33 U.S.C. $\S 1341(\mathrm{a})(2)$ (provision for hearing in which the receiving state can present objections to the issuance of a permit allowing out-of-state discharges that violate the water quality requirements of the receiving state). 334-64.

${ }^{46}$ See, e.g., Stewart, supra note 411 , at $260-61$; Comment, supra note 90 , at

\$17 See supra note 271 and accompanying text.

48 Texas v. Pankey, 441 F.2d 236, 240 (10th Cir. 1971).

48 See supra note 412. 
a damage remedy would also be unavailable under federal common law. Accordingly, the injured individual must resort to state commonlaw remedies. Assuming that the decision in Milwaukee III is followed, the only common law available is that of state $A .^{450}$ If the injured state $B$ resident brings suit in state $A$ 's courts, she will be faced with a potentially hostile forum. The plaintiff can also seek relief in state $B$ 's courts by requesting the application of state $A$ 's common law, but if that law is not as stringent as state $B$ 's law it will not provide the same degree of protection to the plaintiff. By forcing the injured state $B$ plaintiff to sue in a hostile state forum or to resort to state $A$ 's laws, the Milwaukee III decision creates the same threats to legitimacy and intrusions upon state sovereignty that the decision was meant to avoid. ${ }^{\mathbf{4 5 1}}$

Finally, state $B$ can create a statutory or administrative compensation scheme, funded by state $B$ 's tax revenues, to insure that its residents are compensated for harms originating outside the state. Forcing state $B$ 's residents to pay for harms caused by companies in state $A$, however, affronts state $B$ 's sovereignty-and its decision to protect its residents' health and property by adopting pollution controls more stringent than the minimum federal standards-as much as the application of state $B$ 's law to a source in state $A$ impinges upon state $A$ 's sovereignty.

In short, the preemption of state common-law remedies in the interstate context may leave state $B$ without an adequate means of protecting its resources from external harm. The decision in Milwaukee III, then, poses at least as great a threat to state sovereignty and individual liberty as it was designed to avoid. The preemption of state

450 The common law of state $A$ has not been preempted with respect to discharges originating in state $A$. See supra notes $363-86$ and accompanying text; see also Milwaukee III, 731 F.2d at 414 (Section 505(e) of the Clean Water Act, 33 U.S.C. $\S 1365(\mathrm{e})$," $m a y$ well preserve a right under statutes or the common law of the state within which a discharge occurs . . ., and we see no reason why such a right could not be asserted by an out-of-state plaintiff injured as a result of the violation.").

451 See supra notes 434-35 and accompanying text. The infringement on state $B$ 's sovereignty caused by forcing state $B$ and its residents to seek redress for environmental harms in a nonneutral forum could be lessened if the choice of law rules of state $A$ pointed to state $B$ as the source of the applicable substantive law. $C f$. infra note 452 . However, the court in Ouellette v. International Paper Co., 602 F. Supp. 264 (D. Vt. 1985), criticized the decision in Milwaukee III for creating "a choice-of-law rule that deviates, without legislative authorization, from well-settled choice of law principles." Id. at 270. According to the court in Ouellette, the Milwaukee III analysis would require a federal court to resolve an interstate pollution dispute by resort to the law of the state from which the pollution emanates, regardless of the forum state's choice-oflaw principles. See id. "Yet the [Clean Water Act] provides no support for this deviation from the rule that, in a diversity case, a federal court must apply choice of law principles of the state in which the court sits." Id. (citing Klaxon Go. v. Stentor Elec. Mfg. Co., 313 U.S. 487 (1941)). 
common law may in fact be more intrusive on state sovereignty. ${ }^{452}$ The Supreme Court has expressly recognized the "quasi-sovereign" right of a state to protect its resources from external impairment. ${ }^{453}$ In Milwaukee I, the Court concluded that "a state with high water-quality stan-

${ }^{452}$ If a plaintiff injured in state $B$, the receiving state, sued the polluter, company $A$, in a state $B$ court, any infringement on the sovereignty of state $A$ could be mitigated by several factors. The suit could not proceed against company $A$ unless the court could exercise personal jurisdiction over that defendant consistent with the due process clause of the fourteenth amendment. Company $A$ might also be able to remove the case to federal court on diversity of citizenship grounds. See 28 U.S.C. $\$ \S 1332,1441$ (1982). Removal might at least provide the defendant with a more neutral forum. Finally, the court, whether state or federal, would have to apply choice of law rules from the forum state, state $B$, to determine the source of the applicable substantive law. See Klaxon Co. v. Stentor Elec. Mfg. Co., 313 U.S. 487 (1941). It is conceivable that those rules would point to the substantive law of state $A$. $C f$. Chance v. E.I. du Pont De Nemours \& Co., 371 F. Supp. 439, 444, 446 (E.D.N.Y. 1974) (recognizing that, in a personal injury action, the law of the state where the accident occurred will not always be controlling and that the interest of the state in which the defendant is located should sometimes be considered when determining which state has the greatest concern with the specific issue raised in the litigation); Restatement (SECOND) of Conflict of Laws $\S 6(2)$ (c) (1971) (Absent a statutory directive from the forum state, the policies of other interested states and the relative interests of those states in the determination of particular issues should assist the forum state in resolving choice of law questions.).

Moreover, even if a state $B$ court applies state $B$ law to resolve the dispute, the impact on state $A$ 's sovereign interests could be further reduced by limiting the state $B$ plaintiff to damages for past injury and by refusing to issue injunctive relief directly requiring the polluter to limit its emissions to levels below those permitted by federal and state $A$ law. See Weinstein, The Reemergence of Nuisance Law in Environmental Litigation, LAND Use L. \& ZonING Dig., Mar. 1984, at 3, 6. But see Ouellette v. International Paper Co., 602 F. Supp. 264 (D. Vt. 1985) (citing Watson v. Employers Liability Assurance Corp., 348 U.S. 66 (1954); Bowles v. Zimmer Mfg. Co., 277 F.2d 868, 872-77 (7th Cir. 1960)). The district court in Ouellette found that if a state court issued an injunction abating pollution by a private polluter of another state,

any intrusion on the sovereignty of the polluter state is purely incidental. A state's nuisance law develops not to regulate the activity of neighboring states but to protect the health, welfare, and property rights of its own residents. The application of state law in this situation is no more intrusive on the sovereignty of foreign states than the application of one state's product liability law to a manufacturer located in another state.

602 F. Supp. at 271-72. By limiting the available relief to damage awards, the courts could also avoid potential difficulties under the full faith and credit clause. U.S. Consr. art. IV, $\S 1$ ("Full Faith and Credit shall be given in each State to the . . . judicial Proceedings of every other State."). It is not clear whether this clause would require state $A$ to enforce an equitable decree issued by a state $B$ court. See Comment, supra note 90 , at 397 n.474.

4ss See Milwaukee I, 406 U.S. at 104 (citing Georgia v. Tennessee Copper, 206 U.S. 230, 237 (1907)); see also supra notes 186-89 and accompanying text (Protecting a sovereign state's self-determination and citizen participation in government promotes the value of individual liberty.); Milwaukee I, 406 U.S. at 99-100, $107 \mathrm{n} .9$ (Where one state changes its method of draining surface water, thereby increasing the flow of an interstate stream to the detriment of farms in another state, that second state, having a quasi-sovereign interest in the welfare of its farmowners, may bring an action for injunctive relief against the state causing injury) (citing Texas v. Pankey, 441 F.2d 236, 241-42 (10th Cir. 1971); North Dakota v. Minnesota, 263 U.S. 365, 374 (1923)). 
dards may well ask that its strict standards be honored and that it not be compelled to lower itself to the more degrading standards of a neighbor." ${ }^{454}$ A decision barring state $B$ from applying its common law to a state $A$ polluter prevents the former from insisting that its strict standards be honored by polluters in state $A$.

Even if the threat to state $B$ 's sovereignty resulting from the decision in Milwaukee III is no greater than the infringement on state $A$ 's sovereignty caused by the application of state $B$ 's common law, the other components of the value of individual liberty justify the preservation of state common-law remedies. Applying state common law to an interstate dispute furthers the principle of separation of powers ${ }^{455}$ and protects the integrity of the individual from external harms ${ }^{456}$ to the same extent as it does in an intrastate dispute. Accordingly, the preservation of state $B$ 's common-law remedies will promote individual liberty to a greater degree than the preemption of those remedies.

The final value, that of accommodation, supports the preemption of state common-law remedies in an interstate dispute. The court in Milwaukee III concluded that the preemption of state common-law remedies was dictated by the need to accommodate conflicting federal and state interests through the application of a uniform set of federal standards. ${ }^{457}$ Congress, however, did not insist upon uniformity for its own sake; it expressly authorized the states to adopt standards more stringent than the minimum federal standards. It is the potential for conflict among states with differing plans for resource exploitation that supports the application of uniform federal rules. ${ }^{458}$ Thus, the Milwaukee III decision is most convincing in its determination to avoid a "chaotic confrontation between sovereign states"459 by insuring that an interstate discharger cannot be forced to comply with the emission

454 406 U.S. at 107; cf. Kansas v. Golorado, 206 U.S. 46, 97 (1907) ("Each State stands on the same level with all the rest. It can impose its own legislation on no one of the others, and is bound to yield its own to none.").

4BS See supra note 391 and accompanying text.

${ }^{458}$ See supra note 394 and accompanying text.

457 See 731 F.2d at $410,414$.

158 See id. at 410 ("When this competition for the use of an interstate body of water involves the interests of different states, apportionment among users is a matter of special federal concern and the subject of federal law.") (citations omitted).

459 Id. at 414; see also Milwaukee I, 406 U.S. at 107 n.9 (As the states' concerns over external impairment of their resources grow, "conflicting disputes" " and " "proliferating contentions" "appear inevitable. Only federal law can provide an adequate means for dealing with these conflicting claims.) (quoting Texas v. Pankey, 441 F.2d 236, 241-42 (10th Cir. 1971)); Milwaukee III, 731 F.2d at 410 ("This is a controversy of federal dimensions, implicating the conflicting rights of states and inappropriate for state law resolution."); of. Stewart, Pyramids of Sacrifice, supra note 67, at 1229 n.129 (Only "significant spillovers" that "might provoke confrontation between sovereign states" justify federal intervention.). 
standards of more than one state. ${ }^{480}$ Even this rationale is unsatisfying, however, because the accommodation of conflicting state interests is achieved by totally sacrificing the interests of the injured state to those of the polluter state. As a federal district court recently pointed out in response to Milwaukee III, there is no evidence to support the conclusion that Congress chose to resolve the conflicting interests of the two states by subordinating the interests of the receiving state to those of the state from which the pollution emanates. ${ }^{461}$ Indeed, the court maintained that if the legislature's intent concerning the appropriate means of apportioning the right to use interstate resources is not clear, then any doubts should be resolved by emphasizing the primary objective of the Clean Water Act-the elimination of pollutant discharges. ${ }^{\mathbf{4 6 2}}$

In attempting to resolve the ambiguities of the preemption question, the courts should rule in favor of preserving state common law for three reasons. First, the Supreme Court has enunciated a presumption against the federal statutory preemption of state law. Because both preemption and preservation will threaten significant values, and because Congress has not made a clear choice among these values, the evidence is not sufficiently compelling to overcome the presumption against preemption. ${ }^{463}$ Second, the Supreme Court has indicated that federal

180 See R. STEWART \& J. KRIER, supra note 78 , at 365 (suggesting that ambient air quality standards "should be established by the federal government because it is best equipped to assess the interdependent needs of the entire nation with respect to air quality, and also most able to avoid parochialism, interstate conflict, and pressure from polluter interests"). But of. Chevron U.S.A., Inc. v. Hammond, 726 F.2d 483, 487 (9th Cir. 1984), cert. denied, 105 S. Ct. 2686 (1985). According to the Ninth Circuit, " $[w]$ hen the emphasis is to protect and strengthen national power, 'occupation' and 'conflict' are easily found while not so easily found when the emphasis is to promote federalism." Id. Furthermore, in areas such as consumer protection, "the emphasis understandably is upon the state's interest particularly and the imperatives of federalism generally." "Id. at 488 (quoting Morseburg v. Balyon, 621 F.2d 972, 977 (9th Cir. 1980)). 1985).

${ }_{61}$ See Ouellette v. International Paper Co., 602 F. Supp. 264, 271-72 (D. Vt.

sez See id. at 271.

163 There is evidence, however, that Congress believed that injuries caused by interstate water pollution could be redressed in state common-law actions with a minimal intrusion on the sovereignty of the state where the pollution originates, and that the Clean Water Act was meant to preserve the availability of those actions. In 1985, the Senate passed a bill to amend the Clean Water Act. See S. 1128, 99th Cong., 1st Sess., 131 CoNG. Rec. S8126-40 (daily ed. June 13, 1985). Section 119(a) of this bill would add a new subsection (e)(3) to the citizen suit provision of the Clean Water Act, 33 U.S.C. § 1365(e), which would read in relevant part as follows:

In any case involving the application of State common . . . law to an instance where a discharge of pollutants arising in another State is alleged to have an adverse effect on the public health or welfare or the attainment of any water quality requirements of such State . . ., a State or municipality shall be considered a citizen of such State for the purpose of filing 
courts should be especially wary of preempting state law in matters traditionally regulated under the state's police powers, such as the protection of public health and safety. ${ }^{464}$ In the absence of a "clear and manifest' " congressional purpose to preempt state law in interstate pollution controversies, the courts should adhere to the assumption that the historic police powers of the states have not been superseded. ${ }^{465}$ Both of these reasons reflect a healthy respect for the preservation of decentralized decisionmaking and local self-determination as a means of promoting individual liberty. ${ }^{486}$ Finally, the courts should rule in favor of preserving common-law remedies in order to avoid the due process questions that would be raised by a contrary holding. ${ }^{467}$ This approach seeks to avoid leaving individuals without any mechanism for redressing an invasion of personal health or property rights by another, and is thus consistent with the constitutional recognition in the due process clause of the primacy of individual liberty. ${ }^{488}$

\section{Commerce Clause Limitations on State Power}

Once a court concludes that Congress did not intend to preempt state common law in interstate pollution disputes, it must then decide

an action in, or seeking removal to, a Federal district court . . . .

S. 1128 , supra, $\S 119$ (a), 131 CoNG. REc. at $\$ 8135$ (daily ed. June 13, 1985). The Senate Report on S. 1128 indicates that the suit may be brought in the federal district court of the state bringing suit or of the state where the cause of action arose, thereby "provid[ing] access to a neutral forum, the Federal courts, for resolution of interstate disputes" for situations not now covered by the diversity of citizenship statute, 28 U.S.G. § 1332 (1982). See S. REP. No. 50, 99th Cong., 1st Sess. 50 (1985). The Report stresses that the amendment does not create new substantive rights, but simply "preserve[s] legal rights which exist by virtue of State statute or common law." Id. Thus, the Senate Report on S. 1128 supports the proposition that under the current statute a state or municipality can resort to its own common law as the basis for a nuisance action in federal district court; it indicates that the new section merely "places a State or municipality in the same position as one of its citizens for the purpose of gaining access to Federal court under the diversity of citizenship jurisdiction." Id. Although the meaning of this statement is not entirely clear, it appears to indicate that a private citizen injured by an out-of-state polluter is not precluded by the current Clean Water Act from suing the out-of-state polluter in a common-law action in federal district court in the plaintiff's state. In such a suit, the normal choice of law principles would apply in determining the applicable substantive law. See id.

464 See, e.g., Huron Portland Cement Co. v. Gity of Detroit, 362 U.S. 440, 443 (1960) ("The intent to supersede the exercise by the State of its police power as to matters not covered by the Federal legislation is not to be inferred from the mere fact that Congress has seen fit to circumscribe its regulation and to occupy a limited field." ") (quoting Savage v. Jones, 225 U.S. 501, 533 (1912)).

${ }^{468}$ See Milwaukee II, 451 U.S. at 316 (quoting Rice v. Santa Fe Elevator Corp., 331 U.S. 218, 230 (1947)).

SBB See supra note 71 and accompanying text.

487 See supra notes $329-48$ and accompanying text.

488 See supra note 73 and accompanying text. 
whether the federal Constitution prohibits a state from applying its own law to an extraterritorial polluter. The commerce clause ${ }^{469}$ contains "an implied limitation on the power of the States to interfere with or impose burdens on interstate commerce." lates evenhandedly to effectuate a legitimate local public interest, and its effects on interstate commerce are only incidental, it will be upheld unless the burden imposed on such commerce is clearly excessive in relation to the putative local benefits.' "2471 A state's application of its common law to prevent or compensate for harm caused by an out-ofstate polluter is an attempt to serve a legitimate local public interest. A state law "designed to free [the state's environment] from pollution . . . clearly falls within the exercise of even the most traditional concept of what is compendiously known as the police power."472 The inquiries into the discriminatory nature of the state's common law and its effects on interstate commerce, however, would be more difficult to resolve.

If a state explicitly applied more stringent standards to out-of-state industries than it applied to local polluters, it would violate the commerce clause. ${ }^{\mathbf{4 7 3}}$ Absent such facially discriminatory rules, however, it will be difficult to prove that the state's courts are treating out-of-state companies less advantageously than state residents. The fact-specific nature of nuisance cases will permit the state's courts to distinguish almost any case from any other one. Furthermore, the Supreme Court has been reluctant, absent -facially discriminatory measures, to invalidate state laws under the commerce clause. ${ }^{474}$

Absent a showing that the state's common law discriminates

469 U.S. CoNST. art. I, $\S 8, \mathrm{cl} .3$.

${ }^{470}$ Arkansas Elec. Coop. Corp. v. Arkansas Pub. Comm'n, 461 U.S. 375, 389 (1983) (footnote omitted).

431 Id. at 393-94 (quoting Pike v. Bruce Church, Inc., 397 U.S. 137, 142 (1970)); see also Huron Portland Cement Co. v. City of Detroit, 362 U.S. 440, 443 (1960) (By granting to Congress the authority to regulate commerce, the Constitution never intended to prevent states from legislating on matters relating to welfare of their citizens, although such legislation might affect commerce indirectly.).

472 Huron Portland Cement Co. v. City of Detroit, 362 U.S. 440, 442 (1960).

473 For example, a state might balance the equities in a nuisance action brought against local defendants but refuse to do so if an out-of-state company were the defendant.

174 See, e.g., Exxon Corp. v. Maryland, 437 U.S. 117, 126 (1978) ("The fact that the burden of a state regulation falls on some interstate companies does not, by itself, establish a claim of discrimination against interstate commerce.") (footnote omitted); see also Stewart, supra note 411, at 255 (noting that the Supreme Court refuses to apply "undue burden" analysis to disputes over natural resources); $c f$. City of Philadelphia v. New Jersey, 437 U.S. 617 (1978) (invalidating a facially discriminatory New Jersey statute prohibiting the importation of wastes originating outside the state, while permitting the disposal of wastes generated in the state). 
against out-of-state dischargers, the controlling question is likely to be whether the burden imposed on interstate commerce is excessive in relation to the benefits it provides to the forum state. ${ }^{475}$ If the effect of applying state $B$ 's common law, for example, is merely to force a state $A$ company to install pollution control technology that it is economically and technically capable of installing, the court may well characterize the resulting "burden" on interstate commerce as incidental. ${ }^{476}$ Even if the burden on the polluting state is a significant one, the burden may not be excessive in light of the injured state's substantial interest in protecting its environment from harm, whether that harm originates within its own state or not. ${ }^{477}$ Only if the burden imposed by state law on interstate commerce "clearly outweighs the State's legitimate purpose does such a regulation violate the Commerce Clause."478

Although the question might be a close one in some cases, the courts will probably be reluctant to find that the application of state common-law remedies to an out-of-state polluter impermissibly burdens interstate commerce. The Supreme Court has indicated that the delegation to Congress of the authority to regulate interstate commerce was "never intended to cut the States off from legislating on all subjects relating to the health, life, and safety of their citizens." 479 When a state tries to regulate in these areas concurrently with the federal government, the Court inquires whether uniformity of regullation is necessary. ${ }^{480}$ In both the air and water pollution areas, Congress has concluded that uniformity of regulation is not required. The two statutes specify only a uniform minimum level of environmental protection,

475 See Minnesota v. Clover Leaf Creamery Co., 449 U.S. 456, 472 (1981).

476 See, e.g., id. at 472 ("'S]ince most dairies package their products in more than one type of container[ ], the inconvenience of having to conform to different packaging requirements . . . should be slight.").

${ }^{477}$ See id. at 473 (Minnesota had a substantial interest in promoting conservation of natural resources and easing solid waste disposal problems.).

${ }^{478} \mathrm{Id}$. at 474 ; see also L. TRIBE, supra note $286, \S 6-12$, at 340 ("State regulations seemingly aimed at furthering public health or safety . . . are less likely to be perceived as 'undue burdens on interstate commerce' than are state regulations evidently seeking to maximize the profits of local businesses.").

479 Huron Portland Cement Co. v. City of Detroit, 362 U.S. 440, 443 (1960) (citations omitted); see also H.P. Hood \& Sons v. Du Mond, 336 U.S. 525, 531-32 (1949) (recognizing a "broad power in the State to protect its inhabitants against perils to health or safety, . . . even by use of measures which bear adversely upon interstate commerce," so long as the state does not "promote its own economic advantages by curtailment or burdening of interstate commerce"); Stewart, supra note 411, at 255 ("The Supreme Court's refusal to apply undue burden analysis to natural resource controversies means that state measures to prohibit, regulate, or tax the use of natural resources will generally survive attack in court so long as [those] measures are not on their face discriminatory.").

${ }^{480}$ See Huron Portland Cement Co. v. City of Detroit, 362 U.S. 440, 444 (1960). 
while expressly authorizing the states to adopt and enforce more stringent standards. ${ }^{481}$ If uniform federal regulation is required, it must be attributed to the national interest in avoiding disputes between two or more states with conflicting desires to use the same resource. This national interest, however, is unlikely to be strong enough to overcome the states' recognized sovereign interest in protecting their environment from outside impairment. ${ }^{482}$

\section{E. Preemption for Hazardous Waste Disposal Purposes}

The framework for analyzing the preemption of state common-law remedies is to a large extent the same under RGRA and GERGLA as it is under the Glean Air and Water Acts. Three factors, however, justify a separate discussion of hazardous waste preemption issues. First, the courts have continued to apply federal common law in resolving certain issues of liability under the two statutes. Second, GERGLA contains a provision that, by negative implication, appears to preempt common-law remedies for interstate harms. Third, the courts have recognized a particularly strong federal interest in the abatement of toxic waste hazards. Despite these factors, it appears that state common-law remedies for intrastate harms are preserved by both statutes. Furthermore, the preemption of state remedies for interstate harms under CERCLA may not apply to actions seeking compensation for personal injury or property damage.

The Supreme Court stated in Milwaukee II that "if federal common law exists, it is because state law cannot be used."483 Several federal courts have held that federal common-law rules govern the disposition of suits under the imminent hazard provisions of RGRA and CERCLA. ${ }^{484}$ These provisions authorize the EPA to bring suit in fed-

481 See supra notes $372-76$ and accompanying text.

482 The Court has indicated that in defining the limits implicitly imposed on the states by the commerce clause, the courts should strive to reconcile state and national power "only by some appraisal and accommodation of the competing demands of the state and national interests involved." " Arkansas Elec. Coop. Corp. v. Arkansas Pub. Comm'n, 461 U.S. 375, 390 (1983) (quoting Southern Pac. Co. v. Arizona ex rel. Sullivan, 325 U.S. 761, 769 (1945)); see also Stewart, supra note 411, at 254 (supporting "a general rule of deference to state environmental measures").

${ }^{483} 451$ U.S. at 313 n.7; see also Fort, supra note 160, at 134 n.18 ("The displacement of state law as the rule of decision is a concomitant feature of federal common law.").

484 See supra note 277. But see United States v. Northeastern Pharmaceutical \& Chem. Co., 579 F. Supp. 823, 837 n.13 (W.D. Mo. 1984) (Because RGRA and CERCLA preempted federal common law, it cannot be used to determine liability under the imminent hazard provisions of the two statutes.) (citing Milwaukee II, 451 U.S. at 31732). 
eral court to enjoin activities that may present an imminent and substantial endangerment to persons' health or the environment. ${ }^{485}$ The courts have also begun to fashion a body of federal common law to determine whether parties obliged under CERCLA to reimburse the government for costs incurred in response to releases of hazardous substances ${ }^{\mathbf{4 8 6}}$ from abandoned or inactive waste disposal sites are jointly and severally liable. ${ }^{\mathbf{4 8 7}}$ This body of federal common law might thus preempt state common-law remedies in cases involving either intrastate or interstate harms caused by exposure to hazardous wastes.

This conclusion is, however, unwarranted because the courts applying federal common law in cases initiated under RGRA and CERCLA are not resorting to federal common law as an independent source of liability. Defendant liability does not result from conduct the courts characterize as nuisances under federal common law; rather, the defendant is liable because its activities subject it to a special form of liability created by Congress. ${ }^{488}$ For example, a defendant whose activities are enjoined under section 7003 of RCRA ${ }^{489}$ is liable because it engaged in conduct prohibited by Congress - the management of hazardous waste in a manner that may present an imminent and substantial endangerment to health or the environment. Congress has simply authorized the federal district courts to determine on a case-by-case basis what constitutes such an endangerment. Similarly, Congress in section

485 See 42 U.S.C.A. $§$ 6973(a) (West 1983 \& Supp. 1985); 42 U.S.C. $§ 9606(a)$.

${ }^{488}$ A "release" of a hazardous substance under CERCLA includes "any spilling, leaking, pumping, pouring, emitting, emptying, discharging, injecting, escaping, leaching, dumping, or disposing into the environment." 42 U.S.C. \$ 9601(22).

487 See supra note 277. Section 107(a) of CERCLA imposes liability on several categories of persons for certain "costs of removal or remedial action" incurred by the federal or state governments. 42 U.S.C. $\$ 9607$ (a). For definitions of the terms "removal" and "remedial," see $i d . \S 9601(23)-(24)$.

${ }^{488}$ See, e.g., United States v. Waste Indus., Inc., 734 F.2d 159, 167 (4th Cir. 1984) (concluding that the imminent hazard provision of RCRA is a congressional mandate for the courts' resort to concepts derived from "the former common law of nuisance" in applying the provisions of the statute). According to the court in Waste Industries, the Milwaukee II decision precluded "the courts' use of federal common law as a source for setting regulatory standards independent of those established by a comprehensive statutory scheme[, but not] Congress' prerogative to empower the courts to apply common-law principles as part of an ongoing regulatory scheme." Id.; see also Hinds, supra note 263, at 2 ("Though the Supreme Court's decision . . . [in Milwaukee $I I]$ appears to remove the federal common law as an independent basis of liability in hazardous waste cases, common law concepts will continue to guide federal courts in fashioning a body of law under the 'imminent hazard' provisions in RCRA and Superfund.") (footnotes omitted). But see Fort, supra note 160, at 167 \& n.207 (arguing that when courts construe a federal statute or fill gaps in legislation, they are making law, and that this lawmaking is one of the "classic illustrations" of federal common law).

48942 U.S.C.A. § 6973 (West 1983 \& Supp. 1985). 
107(a)(1)(A) of GERCLA ${ }^{490}$ requires the owner of any site from which hazardous substances are released to reimburse the EPA for response costs. The courts, pursuant to congressional authorization, determine whether all of the EPA's costs are attributable to the site owner's activities or whether the owner is responsible for only an identifiable portion of the agency's costs. Thus, the courts in these cases merely interpret and apply provisions of the federal statutes that Congress left vague. ${ }^{491}$ Any federal "common law" referred to in these cases is part and parcel of the statutory provisions authorizing its application. There is no independent body of federal common law that automatically preempts state common-law remedies for harms caused by exposure to hazardous waste.

If state common-law remedies in this area have been displaced, they have been preempted by RCRA and CERCLA, rather than automatically obliterated by the creation of an independent body of federal common law. To determine whether these two statutes have preempted state common-law remedies, the courts must engage in the normal preemption analysis applied to all federal statutes. ${ }^{492}$

19042 U.S.C. $\S 9607(a)(1)(A)$.

191 See, e.g., United States v. Stringfellow, 20 Env't Rep. Cas. (BNA) 1905, 1909 (C.D. Cal. 1984) (stating that courts have imposed joint and several liability under CERCLA and the oil spill provisions of the Clean Water Act, 33 U.S.C. $\$ 1321$, "by invoking common law principles in interpreting" the statutory language); United States v. South Carolina Recycling \& Disposal, Inc., 20 Env't Rep. Cas. (BNA) 1753, 1759 n.8 (D.S.C. 1984) (Evolving principles of federal common law were intended by Congress to "guide the courts in fleshing out CERCLA's liability provisions."). The Supreme Court has drawn the same distinction with respect to other statutory programs: "In almost any statutory scheme, there may be a need for judicial interpretation of ambiguous or incomplete provisions. But the authority to construe a statute is fundamentally different from the authority to fashion a new rule or to provide a new remedy which Congress has decided not to adopt." Northwest Airlines v. Transport Workers, 451 U.S. 77, 97 (1981), quoted in Texas Indus., Inc. v. Radcliff Materials, Inc., 451 U.S. 630,646 (1981); cf. Texas Industries, 451 U.S. at 642 (In the absence of the congressional creation of a right of contribution among private party defendants in a civil antitrust suit, the action does not implicate such uniquely federal interests that the courts are required to formulate federal common law to create a right of contribution.).

492 See supra notes 349-62 and accompanying text. This conclusion is supported by the refusal of several courts to authorize the use of federal common law as an independent basis of federal liability for damages in hazardous waste disposal suits on the ground that RCRA and CERCLA provide the exclusive source of that liability. See Philadelphia v. Stepan Chem. Co., 544 F. Supp. 1135, 1146-48 (E.D. Pa. 1982); United States v. Price, 523 F. Supp. 1055, 1069 (D.N.J. 1981), affd, 688 F.2d 204 (3d Cir. 1982).

Even if the federal courts' use of federal common law under the imminent hazard and response cost recovery provisions of RCRA and GERCLA automatically displaced state law, it would still be necessary to determine the extent of the displacement. That inquiry would be analogous to the identification of the scope of the field occupied by a federal statute. It is at least arguable that the "field" occupied by the use of federal common law under the imminent hazard and response cost recovery provisions of 
The first inquiry under this analysis is whether the statutes explicitly preclude the application of state common-law remedies. RCRA does not do so, either for intrastate or interstate harms. The citizen suit provision of RCRA contains a savings clause virtually identical to those in the Clean Air and Water Acts. ${ }^{483}$ On its face, this clause appears to preserve state common-law remedies for both intrastate and interstate harms. Assuming that the savings clause is construed as taking no position on the preemption issue, then the courts must determine whether Congress implicitly precluded the states from applying their own common-law remedies. ${ }^{494}$

GERCLA, on the other hand, can be interpreted as expressly preempting state common-law remedies for certain interstate harms. Section 114 provides that "[n]othing in this chapter shall be construed or interpreted as preempting any State from imposing any additional liability or requirements with respect to the release of hazardous substances within such State." savings clauses of the Clean Air and Water Acts and RCRA in at least two ways. First, section 114 provides that nothing in the "chapter" preempts state law. Thus, Justice Rehnquist's argument in Milwaukee II-that although the citizen suit provision itself does not preempt federal common law, the rest of the statute does ${ }^{498}$-is not available. Second, the effect of the CERCLA savings clause is limited to supplemental common-law remedies for releases "within [the] State." Thus, if a waste disposal site in state $B$ leaks, causing injury in state $B$, state $B$ 's common-law remedies remain available to redress the harm. ${ }^{497}$ If the leak occurs in state $A$, however, state $B$ common-law remedies are not preserved by CERCLA, since the release did not occur "within such State," that is, state $B$. This negative implication of section 114 sup-

RCRA and CERCLA does not encompass private individuals' rights to seek compensation for personal injury or private property damage resulting from exposure to improperly disposed of hazardous wastes. Cf. infra text accompanying notes 498-500 (suggesting that CERCLA does not address and therefore does not preempt state remedies for personal injuries and property damage).

193 See 42 U.S.C. § 6972(f) (1982).

194 The Court's analysis in Milwaukee II discloses that although nothing in the citizen suit provision of RCRA preempts state common law, the rest of the statute may implicitly suggest otherwise. See supra notes 223-24, 368 and accompanying text.

48542 U.S.C. $\$ 9614$ (a) (emphasis added).

496 See 451 U.S. at 329-32.

197 Cf. 42 U.S.C. $\$ 9607(\mathrm{j})$ :

Nothing in .... [section 9607, concerning liability for response costs] shall affect or modify in any way the obligations or liability of any person under any other provision of State or Federal law, including common law, for damages, injury, or loss resulting from a release of any hazardous substance.... 
ports the conclusion that Congress intended to preempt state commonlaw remedies for interstate harms.

The next question is the scope of the field occupied exclusively by the federal government through GERCLA. The statute authorizes federal and state governments to recover both the costs incurred in responding to releases or threatened releases of hazardous substances from hazardous waste facilities and compensatory damages for harm to government-owned natural resources. ${ }^{488}$ Private persons can also seek reimbursement for response costs. ${ }^{498}$ CERCLA, however, does not create any federal statutory mechanisms for private individuals to seek compensation for personal injuries or property damage. ${ }^{500}$ Arguably, the scope of section 114's preemptive effect extends no further than the matters addressed in CERCLA itself. Under this analysis, the statute preempts supplemental state common-law remedies only for the reimbursement of response costs and natural resource damages where the release and harm occur in different states, but not for personal injuries or property damage.

State common-law remedies not expressly preempted or preserved by RGRA and GERGLA may be implicitly preempted by congressional occupation of the hazardous waste disposal field or by the existence of federal objectives that will be frustrated by the use of state common-law remedies. Unfortunately, the legislative histories of the two statutes are just as uninformative as those of the Glean Air and Water Acts.

The courts, however, have implicitly attributed to Congress the desire to achieve objectives that reflect one or more of the four values described in this Article. ${ }^{501}$ The preemption of state common-law remedies for intrastate and interstate harms caused by hazardous waste disposal would affect these values in the same ways as the preemption of state law under the Clean Air and Water Acts, ${ }^{602}$ with one possible exception. The courts that have resorted to federal common law to determine whether parties are jointly and severally liable for response costs under section 107(a) of GERCLA ${ }^{\text {803 }}$ have recognized that the im-

488 See id. $\S 9607(\mathrm{a})(1-4)(\mathrm{A}),(\mathrm{C})$.

409 See id. $\S 9607(\mathrm{a})(1-4)(\mathrm{B})$.

${ }_{800}$ Provisions that would have authorized such compensation were deleted from the Senate bill prior to CERCLA's enactment. See Grad, Remedies for Injuries Caused by Hazardous Waste: The Report and Recommendations of the Superfund 301(e) Study Group, 14 ENvTL. L. REP. 10,105, 10,105 (1984).

so1 See, e.g., United States v. A \& F Materials Co., 578 F. Supp. 1249, 1255 (S.D. Ill. 1984).

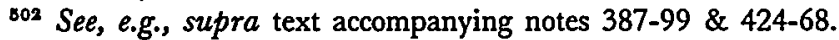

${ }^{803} \mathrm{See} 42$ U.S.C. $\S 9607(\mathrm{a})$. 
proper disposal or release of hazardous substances is "an enormous and complex problem of national magnitude involving uniquely federal interests." "'04 To the extent that state law differs from federal controls and remedies concerning hazardous waste disposal, a conflict between federal and state interests might develop. If the achievement of federal interests requires uniform regulation, the accommodation value supports the subordination of state to federal interests through the preemption of state common-law remedies. ${ }^{505}$

This argument appears to support the preemption of state common-law injunctive relief in either an intrastate or an interstate dispute. It is less tenable, however, with respect to state compensatory remedies for personal injury or property damage. In United States $v$. $A \in \mathcal{E} F$ Materials Co., ${ }^{508}$ a federal district court listed four reasons for developing a uniform federal common law to govern liability in cases involving the recovery of government response costs under section 107(a) of CERCLA. ${ }^{507}$ Three of these reasons, which could also apply to the control of hazardous waste disposal under RCRA, do not dictate the preemption of all state compensatory remedies. First, CERGLA and RCRA represent "a substantial special federal interest in the abatement of toxic waste hazards." ${ }^{\text {(nos }}$ Only standards that are more lenient than the federal standards for hazardous waste treatment, storage, or disposal threaten the goal of abatement. ${ }^{508}$ An award of damages to an individual injured by waste disposal activities does not conflict with any federal interest in abating the hazard, ${ }^{\mathbf{s 1 0}}$ unless the responsible party is

504 United States v. Chem-Dyne Corp., 572 F. Supp. 802, 808 (S.D. Ohio 1983); see also United States v. A \& F Materials Co., 578 F. Supp. 1249, 1255 (S.D. III. 1984) (emphasizing the need for uniform standards governing hazardous waste disposal and enforcement of those standards); United States v. Wade, 577 F. Supp. 1326, 1338 (E.D. Pa. 1983) (discussing the states' inadequate efforts to deal with the problem of hazardous waste disposal). 1984).

${ }^{s 0 s}$ See United States v. A \& F Materials Co., 578 F. Supp. 1249, 1255 (S.D. Ill.

${ }^{508} 578$ F. Supp. 1249 (S.D. Ill. 1984).

50742 U.S.C. $\S 9607$ (a).

${ }^{508} A$ \& $F$ Materials Co., 578 F. Supp. at 1255 (emphasis added).

${ }^{\circ 09}$ Cf. Exxon Corp. v. Hunt, 21 Env't Rep. Cas. (BNA) 1794 (N.J. Sup. Ct. 1984). The New Jersey Court stated that GERCLA

preempts state taxation of the hazardous waste industry only when the state fund created thereby is used to compensate clean up activities already compensated by Superfund .....

... Given the national interest in cleaning up and removing hazardous waste from our environment, we would be hard pressed to interpret the legislation as prohibiting states from supplementing the federal movement to combat this problem.

Id. at 1801-02.

B10 See Ferebee v. Chevron Chem. Co., 736 F.2d 1529, 1542-43 (D.C. Cir.), cert. denied, 105 S. Ct. 545 (1984). 
unable to pay for cleanup after satisfying a judgment in a state common-law action. ${ }^{511}$ Second, the court indicated that a uniform federal common law was needed to implement and interpret CERCLA's provisions creating liability for government response costs. ${ }^{512}$ The availability of state common-law remedies for the compensation of personal injuries and property damage, areas not covered by CERCLA, would not interfere significantly with the implementation of the Act. ${ }^{513}$ Third, the court noted the federal government's interest in preserving the integrity of the Superfund. ${ }^{514}$ An award of damages to an injured individual could jeopardize the integrity of the Fund, since payment of a state tort claim might leave the responsible party financially incapable of reimbursing the government for cleanup costs.

The court's final explanation for the development of uniform federal common law was the desire to prevent excessive dumping in states with more lenient laws. ${ }^{516}$ This federal interest might be impaired by the development of different state standards for injunctive relief and liability. A disproportionate amount of hazardous waste disposal might occur in states whose courts make injunctive relief or damage recoveries more difficult for injured plaintiffs to obtain. ${ }^{\mathbf{1 6}}$

Companies engaged in the management of waste, however, will continue to be subject to a uniform federal standard of liability for the reimbursement of response costs incurred by the EPA in cleaning up waste sites, regardless of their locations. ${ }^{517}$ The magnitude of section 107(a) response cost liability can be staggering, where, for example, chemical wastes leak from a disposal site into a source of drinking water. Companies may decide that shopping around for a state with favorable common-law standards will not reduce their risk of liability sufficiently to be worth the effort. Furthermore, a company will have to

o11 In that event, the EPA could rely on money from the Superfund if the site were on the National Priorities List. See 42 U.S.C. \$ 9611(a).

$\checkmark 12$ See A \& F Materials Co., 578 F. Supp. at 1255.

o1s It is again possible that after paying a personal injury award, the owner of a disposal facility or other responsible person would lack the funds to reimburse the government for its response costs.

${ }^{614}$ See $A \mathcal{E}^{\circ} F$ Materials Co., 578 F. Supp. at 1255.

s1s See id.; see also United States v. Chem-Dyne Corp., 572 F. Supp. 802, 807 (S.D. Ohio 1983) (" "To insure the development of a uniform rule of law, and to discourage business dealing in hazardous substances from locating primarily in States with more lenient laws, the bill will encourage the further development of a Federal common law in this area." ") (quoting 126 CoNG. REC. H11,787 (daily ed. Nov. 24, 1980) (statement of Rep. Florio)).

s16 State courts can develop different rules, for example, concerning the propriety of strict or joint and several liability. A state that adopts substantive or procedural rules advantageous to a person whose disposal activities cause harm could attract a disproportionately high level of disposal.

${ }^{617}$ See 42 U.S.C. § 9607(a). 
consider whether it is willing to incur the costs and run the risks of the interstate and, in some cases, long-range transport of wastes. If an accident in transit results in a release, the company that arranged the transport may be exposed to significant additional liabilities under both federal and state law. The possibility that the state of disposal will apply a common-law standard more favorable to the defendant in a negligence, nuisance, or other common-law action may be outweighed by these additional costs and risks.

The argument that state common-law remedies might conflict with a need for national uniformity, even if otherwise persuasive, goes too far. If the application of varying state common-law injunctive or compensatory relief conflicts with federal abatement efforts by draining the financial resources of responsible parties or by encouraging dumping in states with lenient standards, these adverse consequences would result whether the harm were intrastate or interstate in character. The financial solvency of a dump-site owner, for example, would be threatened just as much by a large award of compensatory damages to a plaintiff located in the same state as it would by a judgment for an injured party residing in another state. But Congress preserved state tort remedies for intrastate harms under CERCLA, ${ }^{\mathbf{5 1 8}}$ and apparently also did so under RCRA. ${ }^{518}$ Congress, therefore, could not have concluded that the need for national uniformity mandates the preemption of all supplemental state common-law remedies. Since intrastate remedies are preserved, any concern for national uniformity must be based on a desire to pre-

${ }^{618}$ See id. $\S 9614(\mathrm{a}) ;$ cf. supra notes 495-97 and accompanying text (discussing the savings clause of GERCLA, 42 U.S.C. $\$$ 9614).

810 See 42 U.S.C. $\S$ 6972(f) (1982); see also 42 U.S.C.A. $§ 6929$ (West 1983 \& Supp. 1985) (A state may impose, and by implication, enforce, requirements for hazardous wastes that are more stringent than those set forth by the federal government.). Several courts have permitted plaintiffs to seek both injunctive and compensatory remedies on state common-law theories in hazardous waste disposal cases, although these courts have not analyzed the preemption issue in depth. See, e.g., United States v. Allied Chem. Corp., 587 F. Supp. 1205, 1209 (N.D. Cal. 1984) (In complaining of a release of hazardous substances, plaintiff sufficiently stated a cause of action in nuisance and trespass under state common law.); Philadelphia Elec. Co. v. Hercules, Inc., 587 F. Supp. 144 (E.D. Pa. 1984) (finding that continuing nuisance was grounds for damages as well as injunctive relief); United States v. Stringfellow, 20 Env't Rep. Cas. (BNA) 1905, 1912 (C.D. Cal. 1984) (Under California law of nuisance, a plaintiff can recover against any defendant that does not show, by a preponderance of the evidence, that its liability should be limited.). Engaging in a more extensive treatment of the issue, the Supreme Court of West Virginia concluded that RGRA does not preempt state common-law public nuisance actions. See Sharon Steel Corp. v. Fairmont, 22 Env't Rep. Cas. (BNA) 1983 (1985). For various arguments supporting the availability of state common-law remedies for persons harmed by exposure to hazardous wastes, see generally Note, Hazardous Wastes: Preserving the Nuisance Remedy, 33 StaN. L. REv. 675 (1981); Note, Hazardous Waste Disposal: Is There Still a Role for Common Law?, 18 TulsA L.J. 448 (1983). 
vent confrontations between the states, the same component of the accommodation value used to support preemption of state common-law remedies in Milwaukee III.

Both RCRA and GERCLA appear to preserve state common-law remedies for intrastate harms. Even if congressional intent on the preemption issue is not explicitly reflected in the language of the statutes, there is no basis for concluding that Congress implicitly preempted the field of hazardous waste disposal. The values of legitimacy, efficiency, and especially individual liberty support preserving state remedies for intrastate harms, ${ }^{\mathbf{5 2 0}}$ and the legislative history does not reveal any congressional determination that other values would be impaired by preserving state law. CERCLA's preemption of state common-law remedies for interstate harm arguably applies only to the recovery of response costs. Although the values of legitimacy and accommodation may support the preemption of other state remedies, ${ }^{, 21}$ the values of individual liberty and efficiency appear to support their preservation. ${ }^{\mathbf{5 2 2}}$ Because of the presumption against federal preemption of state law, the courts' reluctance to preempt state efforts to protect public health and safety, and the due process difficulties presented by the preclusion of state common-law compensatory remedies, ${ }^{523}$ the courts should conclude that Congress has not implicitly preempted these state remedies for interstate harm by enacting RCRA and CERGLA.

\section{F. Re-creation of Private Federal Remedies}

Since the application of common-law remedies to an intrastate dispute is supported by at least three of the four values described in this Article-legitimacy, individual liberty, and efficiency-Congress need not take any action concerning these remedies. ${ }^{824}$ Invoking state common-law remedies in an interstate dispute, however, raises serious considerations of legitimacy and accommodation. Congress can eliminate these difficulties by amending each of the four statutes to do one of two things. First, Congress could reverse Milwaukee II and restore a modified form of federal common law in the area of pollution control, which would authorize the federal courts to award damages to victorious private plaintiffs. Second, Congress could create a statutory private right

\footnotetext{
${ }^{520}$ See supra notes 387-99 and accompanying text.

s22 See supra notes 423-26, 457-60 and accompanying text.

522 See supra notes $429-56$ and accompanying text.

s23 See supra notes $329-48$ and accompanying text.
}

824 Congress could adopt a clarifying amendment affirmatively stating that state common-law remedies for intrastate harms have survived the enactment of the four federal statutes. 
of action for persons harmed by air or water pollution or by exposure to hazardous wastes.

The adoption of either one of these alternatives would avoid the problems raised by using state common law to resolve an interstate dispute. These proposals would eliminate any perception of unfairness caused by discriminatory application of one state's law to out-of-state sources because interstate disputes could be resolved in a neutral forum using federal law. The potential for interstate conflict could also be minimized by dictating a single body of federal rules applicable to companies whose discharges cross state lines. ${ }^{\mathbf{5 2 5}}$ Thus, the creation of federal remedies would foster the values of both legitimacy and accommodation.

At the same time, the revival of federal common law or the creation of a private federal damage action would overcome the current disadvantages arising from the preemption of state common-law remedies in interstate disputes. The availability of a federal judicial forum to injured persons furthers legitimacy by adding an opportunity for public participation in formulating pollution control standards and remedies. A federal action, if accompanied by the preemption of state law in interstate disputes, eliminates the possibility of one state intruding upon the sovereignty of another, while preserving-in much the same way as the Court did in Georgia v. Tennessee Copper Co. ${ }^{526}$-a state's ability to protect its environment from external impairment. Finally, either of the amendments described above can provide a mechanism for individual compensation to substitute for any preempted state common-law remedies, thereby avoiding the due process questions raised by preemption under the current statutes. ${ }^{827}$ If Congress wants to avoid subjecting a discharger to a multiplicity of ad hoc judicial standards of conduct, as feared by the majority in the Milwaukee II case, it can limit federal common-law or statutory remedies to compensatory rather than injunctive relief.

\section{CoNCLUSION}

In the Milwaukee II and National Sea Clammers cases, the Supreme Court held that Congress intended to eliminate from the arsenal of an individual injured by pollution all means of seeking compensation

s28 See Milwaukee II, 451 U.S. at 334 (Blackmun, J., dissenting) (recognizing "the unique role federal common law plays in resolving disputes between one State and the citizens or government of another").

${ }^{826} 206$ U.S. 230 (1907).

${ }^{527}$ See supra text accompanying notes $329-48$ (discussing due process questions raised by the preemption of state remedies). 
under federal law. The evidence supplied by the Court in support of its decisions is less than overwhelming.

The Court has not yet decided whether state common-law injunctive or compensatory remedies have survived the enactment of the Glean Air and Water Acts, RGRA, and GERGLA. With the exception of CERGLA's provision precluding interstate actions for response cost reimbursement, none of these statutes expressly preempts state common-law remedies. Indeed, to the extent the statutes address the issue, they appear to preserve all state common-law remedies.

If the statutory language is not dispositive, one must determine whether Congress has implicitly preempted state common-law remedies for harm caused by pollution. There is no evidence that Congress intended to do so where the injury occurs in the same state in which the pollution is generated. The preservation of state common-law remedies in this context is consistent with the values of legitimacy, individual liberty, and efficiency reflected in the enactment of the four federal pollution control statutes or in applicable constitutional provisions.

If the pollution originates in a state other than the state of injury, the arguments in support of preemption are stronger. The application of one state's common law to a polluter in another state may create perceptions of or actually result in discrimination against out-of-state polluters. It would also infringe upon the sovereignty of the polluter's home state, if that state's pollution control standards are not as stringent as those formulated by the court in the plaintiff's state. On the other hand, the preemption of state common-law compensatory remedies in such a dispute would undermine individual liberty and might violate the due process clause. On balance, the evidence is not sufficiently compelling to overcome the Supreme Court's presumption against preemption in areas of traditional state concern, such as the protection of health and safety. If Congress believes that the disadvantages of applying state common law in an interstate dispute outweigh the advantages, it should create a substitute federal compensatory remedy before preempting state law. 
